Prepared in cooperation with the Puerto Rico Electric Power Authority

\title{
Dam Failure Analysis for the Lago de Matrullas Dam,
} Orocovis, Puerto Rico

Scientific Investigations Report 2015-5065

U.S. Department of the-1nterior U.S. Geological Survey 
Cover: Aerial photograph of the Lago de Matrullas reservoir looking upstream. Photograph courtesy of the Puerto Rico Electric Power Authority. 


\section{Dam Failure Analysis for the Lago de Matrullas Dam, Orocovis, Puerto Rico}

By Heriberto Torres-Sierra and Julieta Gómez-Fragoso

Prepared in cooperation with the Puerto Rico Electric Power Authority

Scientific Investigations Report 2015-5065 


\title{
U.S. Department of the Interior SALLY JEWELL, Secretary
}

\section{U.S. Geological Survey \\ Suzette M. Kimball, Acting Director}

\author{
U.S. Geological Survey, Reston, Virginia: 2015
}

For more information on the USGS - the Federal source for science about the Earth, its natural and living resources, natural hazards, and the environment—visit http://www.usgs.gov or call 1-888-ASK-USGS.

For an overview of USGS information products, including maps, imagery, and publications, visit http://www.usgs.gov/pubprod/.

Any use of trade, firm, or product names is for descriptive purposes only and does not imply endorsement by the U.S. Government.

Although this information product, for the most part, is in the public domain, it also may contain copyrighted materials as noted in the text. Permission to reproduce copyrighted items must be secured from the copyright owner.

Suggested citation:

Torres-Sierra, Heriberto, Gómez-Fragoso, Julieta, 2015, Dam failure analysis for the Lago de Matrullas Dam, Orocovis, Puerto Rico: U.S. Geological Survey Scientific Investigations Report 2015-5065, 54 p., http://dx.doi.org/10.3133/sir20155065.

ISSN 2328-0328 (online). 


\section{Acknowledgments}

The authors want to thank and acknowledge all the support to complete the study. Thanks to Carmen Delgado, program coordinator for National Flood Insurance Program at Caribbean area office, for provide the hydraulic study for the Rio Grande de Manatí basin. It is also grateful for the assistance of Manuel Coll, and all personnel of the Bridge Engineering office of the Puerto Rico Highways and Transportation Authority who helped in the collection of geometric data of the bridge structures included in the analysis. Likewise, we want to thank to all U.S. Geological Survey peer reviewers, geographic information system personnel (Marilyn Santiago and Xavier Marti), and Science Publishing Network reviewers for all of their support and help during the review process. 



\section{Contents}

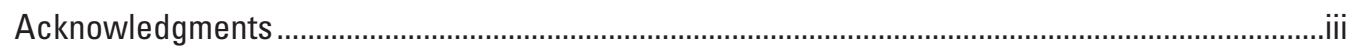

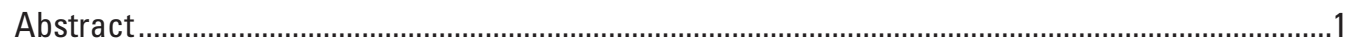

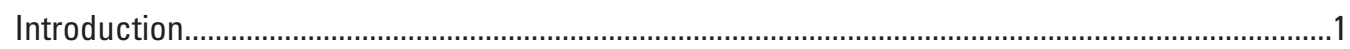

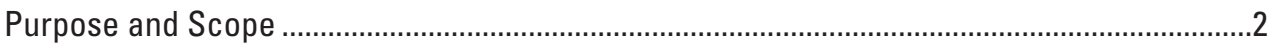

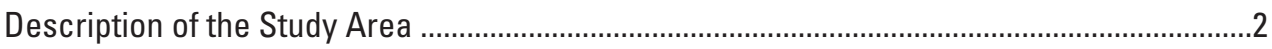

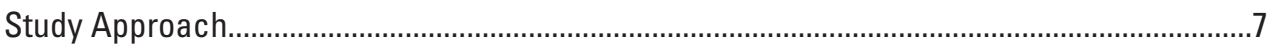

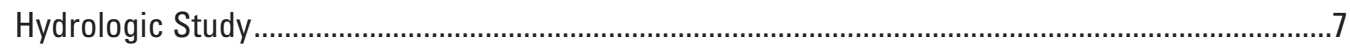

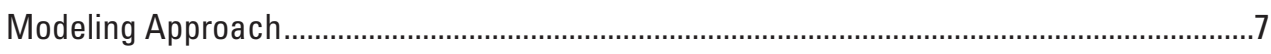

Hydrographic Basin Delineation .........................................................................................

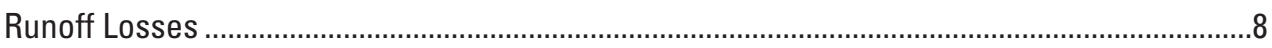

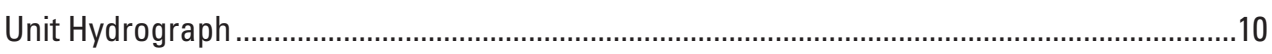

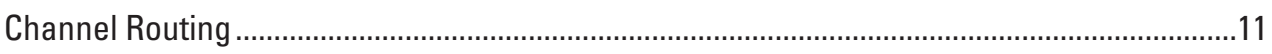

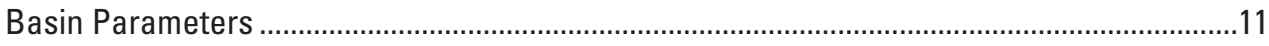

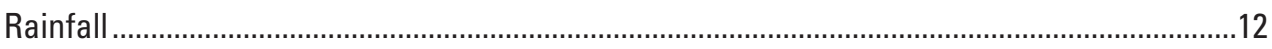

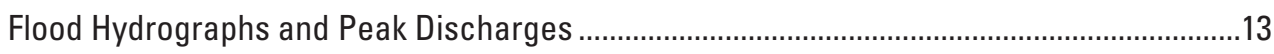

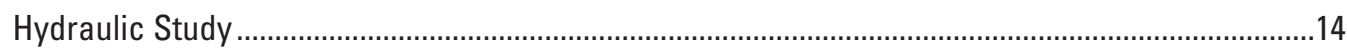

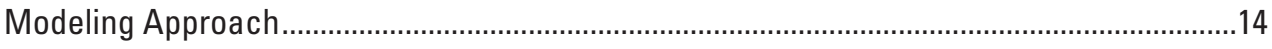

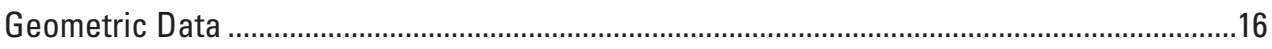

Boundary Conditions, Reach Connections, and Initial Conditions ........................................16

Breach Parameters and Failure Criteria ..............................................................................16

Dam Failure Simulations and Results .................................................................................17

Dam Failure Under Probable Maximum Precipitation Conditions.....................................18

Dam Failure Under 100-Year Flood Conditions ...............................................................20

Dam Failure Under Sunny Day Conditions.......................................................................20

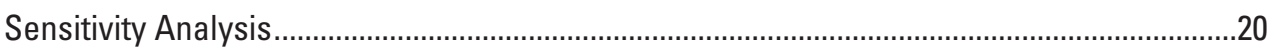

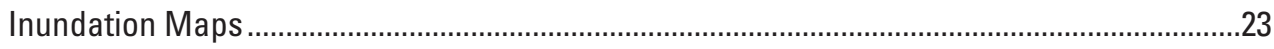

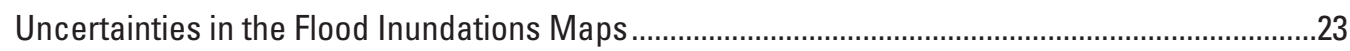

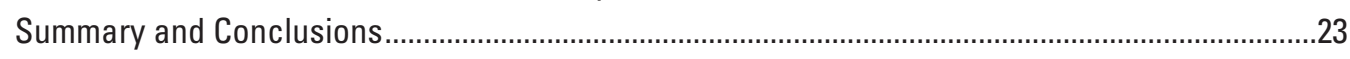

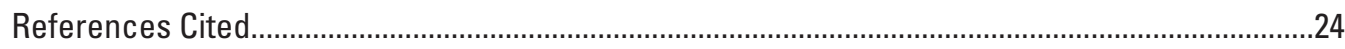

Appendix 1. HEC-HMS Output Hydrographs for the Dam Failure Analysis of Lago de Matrullas,

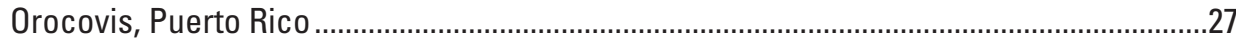

Plates (available at http://pubs.usgs.gov/sir/2015/5065/)

1. 6-hour probable maximum precipitation event........................................... Separate pdf file

2. 24-hour probable maximum precipitation event.......................................Separate pdf file

3. 100-year, 24-hour precipitation event...................................................... Separate pdf file

4. Sunny day condition ................................................................................ Separate pdf file 


\section{Figures}

1-5. Maps showing:

1. Location of Lago de Matrullas in the Río Grande de Manatí hydrographic basin, Puerto Rico .

2. Study subbasins within the Rio Grande de Manatí hydrographic basin used for the dam failure analysis for the Lago de Matrullas Dam, Orocovis, Puerto Rico

3. Land cover within the Río Grande de Manatí hydrographic basin, Puerto Rico .6

4. Hydrologic soil groups within the Río Grande de Manatí drainage basin .9

5. Hydraulic system simulated as part of the dam failure analysis for the Lago de Matrullas Dam, Orocovis, Puerto Rico

6. Graph showing maximum water-surface profile along the lower reach of the Río Grande de Manatí for the 6-hour probable maximum precipitation for the dam failure analysis of the Lago de Matrullas Dam, Orocovis, Puerto Rico

\section{Tables}

1. Principal characteristics of Lago de Matrullas Dam, Orocovis, Puerto Rico

2. Curve number used in the hydrologic analysis based on hydrologic groups and land cover data used for the dam failure analysis of Lago de Matrullas Dam, Orocovis, Puerto Rico

3. Basin parameters for the study of subbasins within the Río Grande de Manatí hydrographic basin used for the dam failure analysis of Lago de Matrullas Dam, Orocovis, Puerto Rico

4. Computed rainfall depths at each subbasin for the selected frequency-based hypothetical storms used for the dam failure analysis of Lago de Matrullas Dam, Orocovis, Puerto Rico

5. Peak discharges at each subbasin resulting from simulated rainfall events used for the dam failure analysis of Lago de Matrullas Dam, Orocovis, Puerto Rico

6. Peak inflow and outflow discharge of Lago de Matrullas Dam, Orocovis, Puerto Rico, for the simulated rainfall events

7. Breach parameters used for the dam failure analysis of Lago de Matrullas Dam, Orocovis, Puerto Rico

8. Results for the 6-hour probable maximum precipitation at selected cross sections along the lower reach of the Río Grande de Manatí for the dam failure analysis of Lago de Matrullas Dam, Orocovis, Puerto Rico.

9. Results for the 24-hour probable maximum precipitation at selected cross sections along the lower reach of the Río Grande de Manatí for the dam failure analysis of Lago de Matrullas Dam, Orocovis, Puerto Rico.

10. Results for the 24-hour, 100 -year rainfall event at selected cross sections along the lower reach of the Río Grande de Manatí for the dam failure analysis of Lago de Matrullas Dam, Orocovis, Puerto Rico

11. Results for sunny day conditions at selected cross sections along the lower reach of the Río Grande de Manatí for the dam failure analysis of Lago de Matrullas Dam, Orocovis, Puerto Rico 
12. Breach parameters used in the sensitivity analysis considering adjustments in the final bottom-width for the dam failure analysis of Lago de Matrullas Dam,

Orocovis, Puerto Rico

13. Breach parameters used in the sensitivity analysis considering adjustments in the breach formation time for the dam failure analysis of Lago de Matrullas Dam,

Orocovis, Puerto Rico

14. Peak discharge at Lago de Matrullas Dam, Orocovis Puerto Rico for the sensitivity analysis of breach parameters

\section{Conversion Factors}

\begin{tabular}{|c|c|c|}
\hline Multiply & By & To obtain \\
\hline \multicolumn{3}{|c|}{ Length } \\
\hline centimeter $(\mathrm{cm})$ & 0.3937 & inch (in.) \\
\hline millimeter $(\mathrm{mm})$ & 0.03937 & inch (in.) \\
\hline meter $(\mathrm{m})$ & 3.281 & foot $(\mathrm{ft})$ \\
\hline kilometer $(\mathrm{km})$ & 0.6214 & mile (mi) \\
\hline \multicolumn{3}{|c|}{ Area } \\
\hline square kilometer $\left(\mathrm{km}^{2}\right)$ & 247.1 & acre \\
\hline square kilometer $\left(\mathrm{km}^{2}\right)$ & 0.3861 & square mile $\left(\mathrm{mi}^{2}\right)$ \\
\hline \multicolumn{3}{|c|}{ Volume } \\
\hline cubic meter $\left(\mathrm{m}^{3}\right)$ & 0.0002642 & million gallons (Mgal) \\
\hline cubic meter $\left(\mathrm{m}^{3}\right)$ & 35.31 & cubic foot $\left(\mathrm{ft}^{3}\right)$ \\
\hline cubic meter $\left(\mathrm{m}^{3}\right)$ & 0.0008107 & acre-foot (acre-ft) \\
\hline million cubic meters $\left(\mathrm{Mm}^{3}\right)$ & 2,642 & million gallons (Mgal) \\
\hline \multicolumn{3}{|c|}{ Flow rate } \\
\hline cubic meter per second $\left(\mathrm{m}^{3} / \mathrm{s}\right)$ & 70.07 & acre-foot per day (acre-ft/d) \\
\hline meter per second $(\mathrm{m} / \mathrm{s})$ & 3.281 & foot per second $(\mathrm{ft} / \mathrm{s})$ \\
\hline
\end{tabular}

Temperature in degrees Celsius $\left({ }^{\circ} \mathrm{C}\right)$ may be converted to degrees Fahrenheit $\left({ }^{\circ} \mathrm{F}\right)$ as ${ }^{\circ} \mathrm{F}=\left(1.8 \times{ }^{\circ} \mathrm{C}\right)+32$.

Temperature in degrees Fahrenheit $\left({ }^{\circ} \mathrm{F}\right)$ may be converted to degrees Celsius $\left({ }^{\circ} \mathrm{C}\right)$ as ${ }^{\circ} \mathrm{C}=\left({ }^{\circ} \mathrm{F}-32\right) / 1.8$.

\section{Datum}

Elevation, as used in this report, refers to distance above the vertical datum.

Vertical coordinate information is referenced to local mean sea level

Horizontal coordinate information is referenced to the Puerto Rico Datum, 1940 Adjustment 


\section{Abbreviations}

$\begin{array}{ll}\text { CN } & \text { curve number } \\ \text { EAP } & \text { Emergency Action Plan } \\ \text { HEC-HMS } & \text { Hydrologic Engineering Center's Hydrologic Modeling System } \\ \text { HEC-RAS } & \text { Hydrologic Engineering Center's River Analysis System } \\ \text { NOAA } & \text { National Oceanic and Atmospheric Administration } \\ \text { NRCS } & \text { Natural Resources Conservation Service } \\ \text { PMP } & \text { probable maximum precipitation } \\ \text { PREPA } & \text { Puerto Rico Electric Power Authority } \\ \text { SCS } & \text { Soil Conservation Service } \\ \text { SSURGO } & \text { Soil Survey Geographic (database) } \\ \text { USACE } & \text { U.S. Army Corps of Engineers } \\ \text { USGS } & \text { U.S. Geological Survey }\end{array}$

\section{Translations}

\section{Spanish English}

$\begin{array}{ll}\text { cordillera } & \text { mountain range or chain } \\ \text { lago } & \text { lake } \\ \text { municipio } & \text { usually equivalent to county } \\ \text { quebrada } & \text { creek } \\ \text { río } & \text { river }\end{array}$




\title{
Dam Failure Analysis for the Lago de Matrullas Dam, Orocovis, Puerto Rico
}

\author{
By Heriberto Torres-Sierra ${ }^{1}$ and Julieta Gómez-Fragoso²
}

\section{Abstract}

The U.S. Geological Survey, in cooperation with the Puerto Rico Electric Power Authority, completed a hydrologic and hydraulic study to assess the potential hazard to human life and property associated with the hypothetical failure of the Lago de Matrullas Dam, located within the headwaters of the Río Grande de Manatí. The hydrologic study yielded outflow hydrographs and peak discharges for Lago de Matrullas and other subbasins in the Río Grande de Manatí hydrographic basin for three extreme rainfall events: (1) a 6-hour probable maximum precipitation (PMP) event, (2) a 24-hour PMP event, and (3) a 100-year-recurrence, 24-hour rainfall event. The hydraulic study simulated the hypothetical dam failure of Lago de Matrullas using hypothetical flood hydrographs generated from the hydrologic study and selected dam breach parameters. The flood wave resulting from the failure was downstreamrouted through the lower reaches of the Río Matrullas, the Río Toro Negro, and the Río Grande de Manatí for determination of water-surface profiles developed from the event-based hydrologic scenarios and "sunny day" (no precipitation) conditions. The Hydrologic Modeling System (HEC-HMS) and the River Analysis System (HEC-RAS) computer programs, developed by the Hydrologic Engineering Center (HEC) of the U.S. Army Corps of Engineers, were used for the hydrologic and hydraulic modeling, respectively. The flow routing in the hydraulic analyses was performed using the unsteady-state flow module available in the HEC-RAS model.

At the Lago de Matrullas Dam, inflow peak discharges of about 1,104 and 1,032 cubic meters per second $\left(\mathrm{m}^{3} / \mathrm{s}\right)$ were estimated with HEC-HMS for the 6- and 24-hour PMP events, respectively. The 100-year recurrence, 24-hour rainfall event simulation resulted in a peak discharge of about $418 \mathrm{~m}^{3} / \mathrm{s}$. For the hydrologic analysis, no dam failure conditions were considered with the model. The results of the hydrologic simulations indicated, however, that the dam would be overtopped by the simulated 6- and 24-hour PMP events. Unlike the 6- and 24-hour PMP events, no overtopping was observed during the simulated 100-year recurrence, 24-hour rainfall event.

${ }^{1}$ Retired.

${ }^{2}$ U.S. Geological Survey.
For the dam-breach hydraulic analysis, the hypothetical failures of the Lago de Matrullas Dam included two possible failure modes: overtopping and piping. Overtopping failure was evaluated in this study for the 6- and 24- hour probablemaximum-precipitation breach scenarios. Piping dam failure was simulated for sunny day conditions and for the 100-yearrecurrence, 24-hour rainfall scenario.

Results from the simulated dam failure of the Lago de Matrullas Dam using the HEC-RAS model for the 6- and 24-hour PMP events showed peak discharges at the dam of $3,149.33$ and 3,604.70 $\mathrm{m}^{3} / \mathrm{s}$, respectively. Dam failure during the 100-year-recurrence, 24-hour rainfall event resulted in a peak discharge of $2,103.12 \mathrm{~m}^{3} / \mathrm{s}$ directly downstream from the dam. Dam failure under sunny day conditions produced a peak discharge of $1,695.91 \mathrm{~m}^{3} / \mathrm{s}$ at the dam assuming the antecedent lake level was at the morning-glory spillway invert elevation. Flood-inundation maps prepared as part of the study depict the flood extent and provide valuable information for preparing an Emergency Action Plan. Results of the failure analysis indicate that a failure of the Lago de Matrullas Dam could cause flooding to many of the inhabited areas along stream banks from the Lago de Matrullas Dam to the mouth of the Río Grande de Manatí. Among the areas most affected are the low-lying regions in the vicinity of the towns of Ciales, Manatí, and Barceloneta. The delineation of the flood boundaries near the town of Barceloneta considered the effects of a levee constructed during 2000 at Barceloneta in the flood plain of the Río Grande de Manatí to provide protection against flooding to the near-by low-lying populated areas. The results showed overtopping can be expected in the aforementioned levee during 6-and 24-hour probable-maximum-precipitation dam failure scenarios. No overtopping of the levee was simulated, however, during dam failure scenarios under the 100-year recurrence, 24-hour rainfall event or sunny day conditions.

\section{Introduction}

The National Dam Safety Program and the Puerto Rico Inspection and Regulation of Dams and Reservoirs Program require each dam owner to prepare an Emergency Action Plan (EAP). The EAP must be prepared, maintained, and executed to provide immediate defensive action to prevent or 
minimize property damage, injury, or loss of life in the event of an emergency-flooding situation caused by dam failure. The EAP requires hydrologic and hydraulic analyses of the dam to assess the potential downstream hazard to human life and property. To fulfill this need, the U.S. Geological Survey (USGS) conducted hydrologic and hydraulic analyses of the Lago de Matrullas Dam in Orocovis, Puerto Rico (fig. 1), in cooperation with the Puerto Rico Electric Power Authority (PREPA). The hydrologic analysis included the development of the flood hydrographs resulting from a 6- and a 24-hour probable maximum precipitation (PMP) storm event, as well as a 100 -year-recurrence, 24 -hour rainfall event. Flood hydrographs created as part of the hydrologic analysis were used as the inflow hydrographs to the reservoir in the hydraulic analysis. Thus, no failure conditions were considered during hydrologic modeling.

The hydraulic analysis focused on downstream routing for the breach hydrograph of Lago de Matrullas generated during the dam failure, as well as the flood hydrographs representing runoff from basins downstream of the reservoir. Four failure scenarios were considered in the analysis. Three were event-based hydrologic conditions: the 6- and 24-hour PMP events, and the 100-year recurrence flood (or 100-year, 24-hour rainfall event). The fourth scenario represented non-precipitation conditions, commonly known as "sunny day" conditions. The breach hydrograph resulting from failure of the Lago de Matrullas Dam, as well as other lateral inflows, were downstream routed through the lower reaches of the Río Matrullas, Río Toro Negro, and Río Grande de Manatí (fig. 1).

The results of the hydraulic analysis included flood levels for several locations along the study reach. Maps showing the maximum inundation limits during the passage of the flood wave resulting from each of the four hypothetical dam failure events were constructed for the flooded areas downstream from the Lago de Matrullas Dam, specifically, the lower reach of the Río Grande de Manatí. Information about maximum water-surface elevations and peak flood-wave arrival times are also included on the inundation maps.

\section{Purpose and Scope}

The purpose of this report is to present the results of the hydrologic and hydraulic analyses conducted to assess the potential hazards resulting from hypothetical failure of the Lago de Matrullas Dam under 6- and 24-hour PMP events, the 100-year-recurrence, 24-hour rainfall event, and sunny day conditions. The potential hazard at a specific location was defined in terms of (1) maximum river stage reached at the location during the passage of the flood wave, and (2) flood-wave arrival time at each location.

\section{Description of the Study Area}

The Lago de Matrullas Dam lies within the Municipality of Orocovis (fig. 1) and is part of the Toro Negro Hydroelectric
Project, which consists of two lakes, Lago de Matrullas and Lago El Guineo, and two hydroelectric plants, Toro Negro I and Toro Negro II. The main purpose of these water-management features is to provide a water supply for hydroelectric energy generation and for irrigation. The Lago de Matrullas subbasin (Subbasin 1, fig. 2) is located on the northern slope of the Cordillera Central in the central region of Puerto Rico and is part of the Río Grande de Manatí hydrographic basin. The dam impounds the waters of the Río Matrullas upper basin (Subbasin 1, fig. 2) and encompasses a surface area of about 11.6 square kilometers $\left(\mathrm{km}^{2}\right)$. The Lago de Matrullas Dam is located about 14.4 kilometers $(\mathrm{km})$ north of the town of Ciales and about $9.5 \mathrm{~km}$ west of the town of Orocovis.

The Río Matrullas merges with the Río Toro Negro about $7.5 \mathrm{~km}$ downstream from the Lago de Matrullas Dam. The contributing drainage area of the Río Matrullas at its confluence with the Río Toro Negro is about $21.2 \mathrm{~km}^{2}$ (Subbasin 1 and 2, fig. 2). Lago El Guineo, which impounds waters of the Río Toro Negro upper basin (Subbasin 3, fig. 2) is located about $19.6 \mathrm{~km}$ upstream from the Río Toro Negro-Río Matrullas confluence.

Downstream from the confluence of the Río Matrullas and upstream from its confluence with the Río Grande de Manatí, the Río Toro Negro receives inflow from the Río Bauta subbasin (with a contributing area of $73.3 \mathrm{~km}^{2}$, Subbasin 5, fig. 2). About $7.0 \mathrm{~km}$ downstream from the Río Toro Negro-Río Grande de Manatí confluence, the Río Cialitos drains into the Río Grande de Manatí (Subbasin 8, fig. 2). Downstream from this confluence, the Río Grande de Manatí meanders through about $28.0 \mathrm{~km}$ of a deeply entrenched alluvial valley, flanked on both sides by limestone hills, before reaching the coastal plain.

The Lago de Matrullas Dam is an earthfill embankmenttype dam with a structural height of 36.58 meters (m), a top width of $9.14 \mathrm{~m}$, and a crest length of $216.40 \mathrm{~m}$. Dam construction was completed in 1934, and the dam is currently owned and operated by PREPA (Puerto Rico Electric Power Authority, 1980a). The elevation at the top of the dam ranges from a maximum of $749.77 \mathrm{~m}$ on the left abutment to a minimum of $748.58 \mathrm{~m}$ on the right abutment. An uncontrolled, morning-glory type spillway with a crest elevation of $743.50 \mathrm{~m}$ and a crest diameter of $20.42 \mathrm{~m}$ is located within the dam's right abutment. The spillway discharge passes over the crest of the morning-glory into a tapered shaft, ending in a 5.39-m-diameter circular elbow and sloping tunnel of the same diameter located $33.53 \mathrm{~m}$ below the spillway crest. The tunnel ends in a simple portal structure on the downstream face of the right abutment of the dam with no stilling basin. The spillway discharge capacity at a pool elevation of $745.79 \mathrm{~m}$ is about $425 \mathrm{cubic}$ meters per second $\left(\mathrm{m}^{3} / \mathrm{s}\right)$. Data related to the construction specifications of Lago de Matrullas were obtained from the USGS (Soler-López, 2003a) and from dam inspection reports provided by the PREPA (Puerto Rico Electric Power Authority, 1980a). These data are summarized in table 1. 


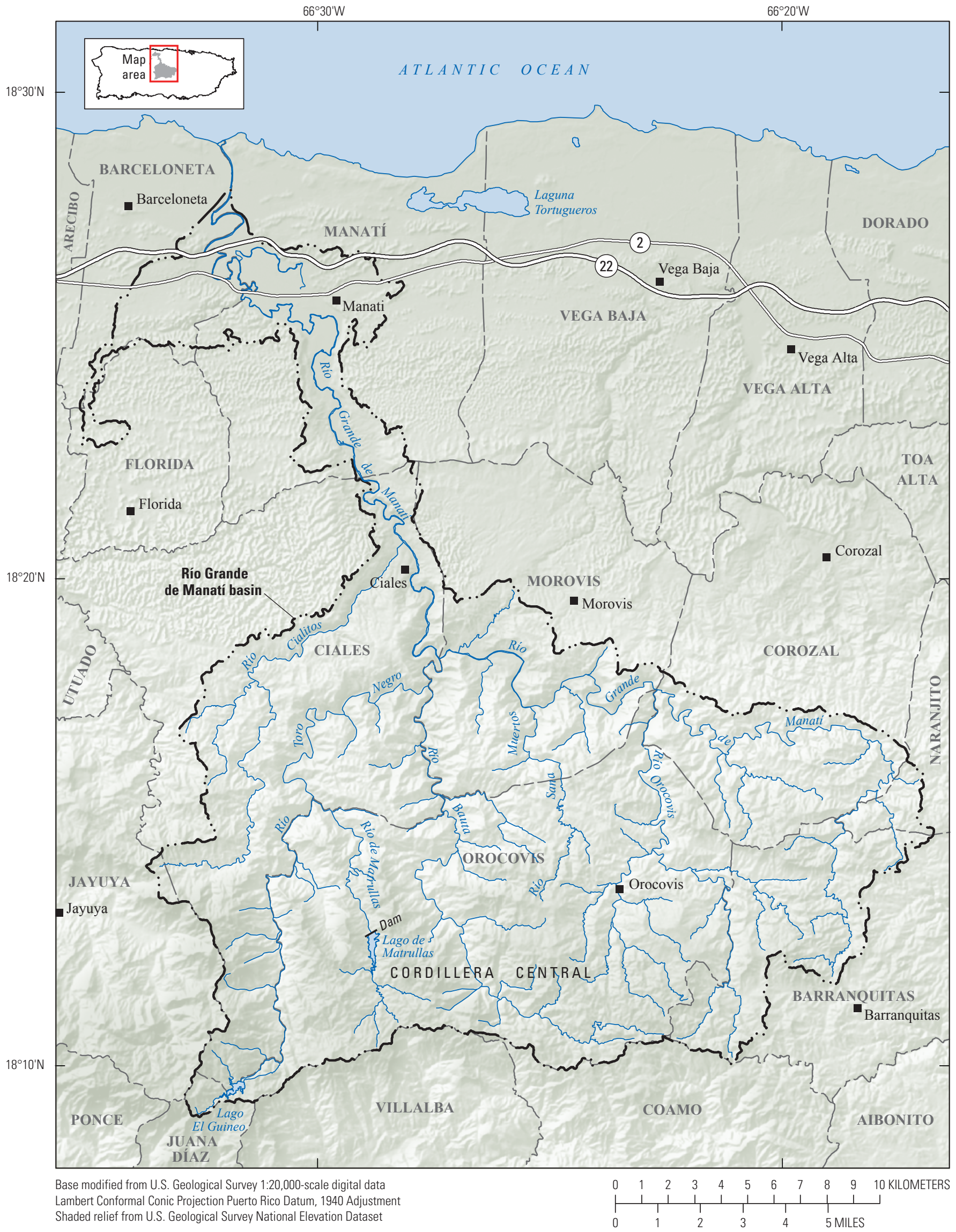

Figure 1. Location of Lago de Matrullas in the Río Grande de Manatí hydrographic basin, Puerto Rico. 


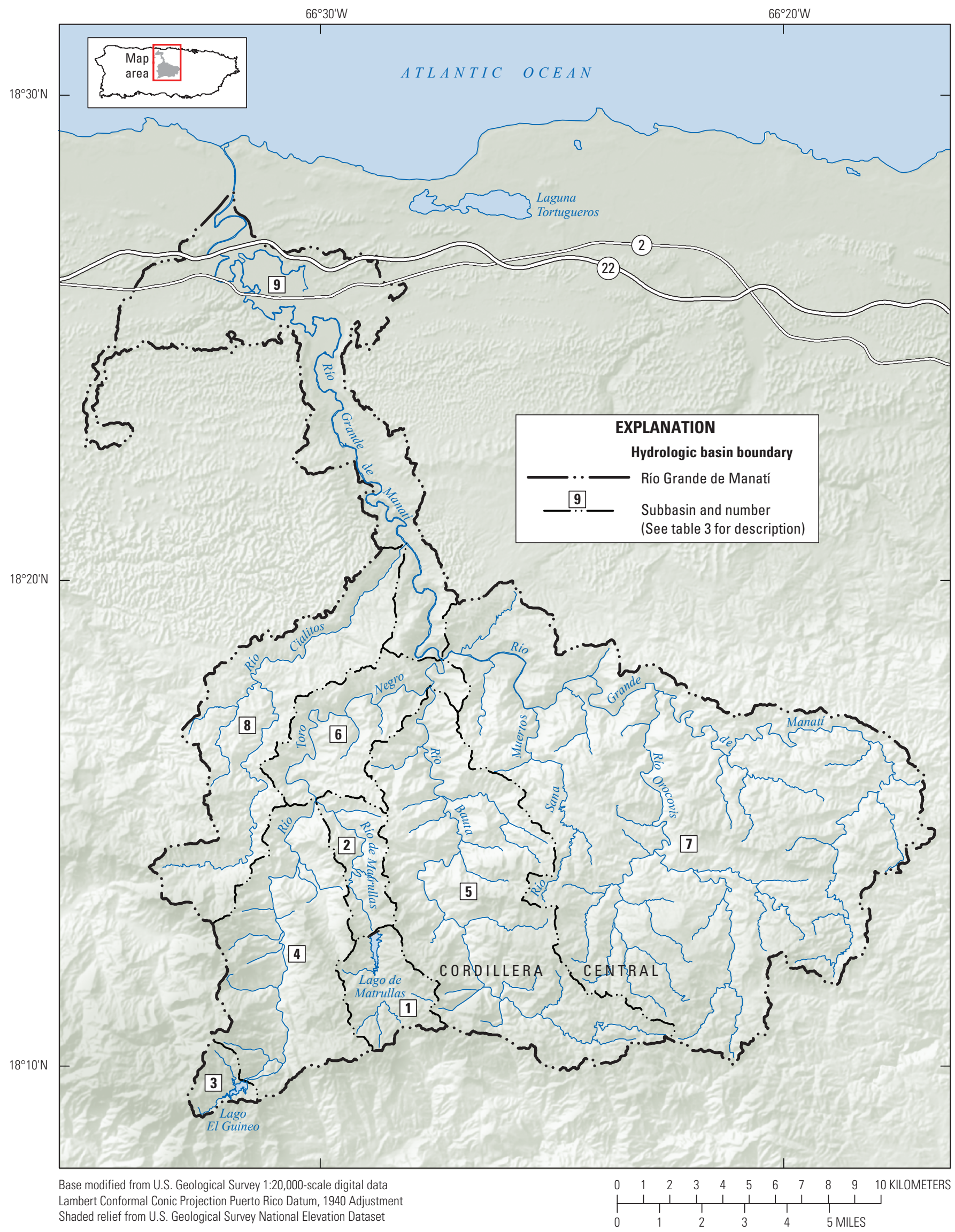

Figure 2. Study subbasins within the Rio Grande de Manatí hydrographic basin used for the dam failure analysis for the Lago de Matrullas Dam, Orocovis, Puerto Rico. 
Table 1. Principal characteristics of Lago de Matrullas Dam, Orocovis, Puerto Rico.

\begin{tabular}{|ll}
\hline \multicolumn{1}{|c}{ Dam characteristic } & \multicolumn{1}{c}{ Description or value } \\
\hline Dam type & $\begin{array}{c}\text { Earthfill embankment with } \\
\text { rock toes }\end{array}$ \\
\hline Spillway type & $\begin{array}{c}\text { Uncontrolled morning- } \\
\text { glory with vertical shaft } \\
\text { and sloping tunnel }\end{array}$ \\
\hline Length of dam, in meters & 216.40 \\
\hline $\begin{array}{l}\text { Height of dam, in meters } \\
\text { Dam crest elevation, in meters } \\
\text { above mean sea level } \\
\quad \text { Minimum } \\
\quad \text { Maximum }\end{array}$ & 36.58 \\
\hline $\begin{array}{l}\text { Spillway crest elevation, in } \\
\text { meters above mean sea level }\end{array}$ & 748.58 \\
\hline $\begin{array}{l}\text { Dam crest width, in meters } \\
\text { Storage capacity (2001), in million } \\
\text { cubic meters }\end{array}$ & 3.08 \\
\hline
\end{tabular}

The Lago de Matrullas Dam was constructed to provide 3.71 million cubic meters $\left(\mathrm{Mm}^{3}\right)$ of water storage for hydroelectric power generation and to increase water supply for irrigation of croplands in the southern coastal plains of the island. The original storage capacity of $3.71 \mathrm{Mm}^{3}$ (1934) was found to have been reduced by sedimentation to $3.22 \mathrm{Mm}^{3}$ in 1986 and to $3.08 \mathrm{Mm}^{3}$ in 2001 (Soler-López, 2003a). This reduction represents a storage-capacity loss of 0.25 percent per year.

The principal tributary to the reservoir is the Río Matrullas, which originates in the northern slopes of the Cordillera Central mountain range, where the overall stream channel slope is about 6 percent. The tributary streams of the Río Matrullas are formed by a series of unnamed creeks, some of which originate at elevations in excess of $1,000 \mathrm{~m}$ and have channel slopes of about 40 percent.

Land cover within the Río Grande de Manatí hydrographic basin includes evergreen forest, shrub/scrub, hay/ pasture/herbaceous, barren land, developed land (open space to high density), and cultivated crops (fig. 3; National Resources Conservation Service, 2003). Evergreen forests and hay/pasture/herbaceous cover the largest amount (54 and 36 percent, respectively) of the total area of the Río Grande de Manatí hydrographic basin, and each of the remaining aforementioned categories cover less than 1 to 5 percent of the total hydrographic basin area. In the highlands of the hydrographic basin, land cover mostly consists of evergreen forest, shrub/ scrub, cultivated crops, and undeveloped land. Most of the developed lands are located in downstream reaches near the coast (fig. 3).

The Río Grande de Manatí hydrographic basin is composed of a variety of soil series (Natural Resources Conservation Service, 2013); the Mucara series (MuE, MuF, MuF2, MxE, and MxF) composes the highest (20 percent) percentage of the total area. The Maricao soil series $(\mathrm{MoF}, \mathrm{McF}$, and MxF2) composes approximately 15 percent of the total area and the Los Guineos soil series (LgD, LgE, LgF, LsE, LsF, $\mathrm{LuE}$, and $\mathrm{LuF}$ ) composes 11 percent. The Mucara and Maricao soil series both consist of well-drained soils having moderate permeability and slopes ranging from 5 to 60 percent and from 20 to 90 percent, respectively. 


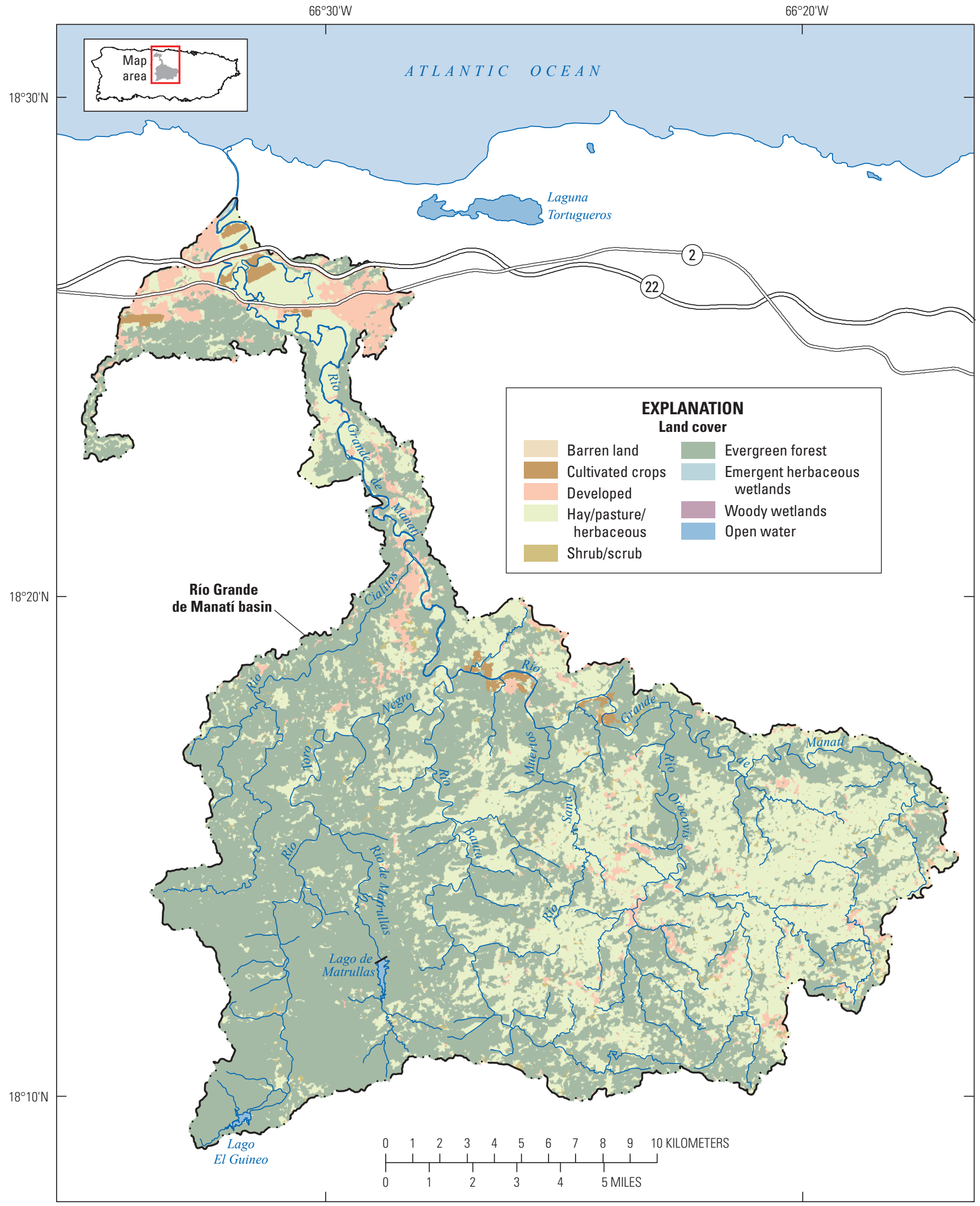

Base modified from U.S. Geological Survey 1:20,000-scale digital data Lambert Conformal Conic Projection Puerto Rico Datum, 1940 Adjustment

Figure 3. Land cover within the Río Grande de Manatí hydrographic basin, Puerto Rico. Land-cover data are from Natural Resources Conservation Service (2003). 
The drainage basin impounded by Lago de Matrullas is composed of the Los Guineos soil series (LsF and LsE) (Boccheciamp, 1978). The LsF clay, with hill slopes ranging from 40 to 60 percent, covers about 90 percent $\left(10.3 \mathrm{~km}^{2}\right)$ of the Lago de Matrullas drainage basin. The LsE clay is characterized by hilltops with slopes ranging from 20 to 40 percent. These soil series consist of moderately welldrained soil, moderate to very steep slopes, and moderately slow permeability, with a moderate erosion hazard. Typically, the surface layer consists of a dark yellowish brown, friable clay about 10 centimeters $(\mathrm{cm})$ thick and the subsoil is composed of firm clay about $110 \mathrm{~cm}$ thick. The Natural Resource Conservation Service (NRCS) classifies these soils in hydrologic soil group C (Natural Resources Conservation Service, 2013), which includes soils of moderately fine to fine texture with low infiltration rates when thoroughly wetted and a low water-transmission rate.

The mean annual rainfall in the coastal area within the Río Grande de Manatí hydrographic basin is about 1,566 millimeters $(\mathrm{mm})$ at Manatí $2 \mathrm{E}$ weather station (National Oceanic and Atmospheric Administration [NOAA], 2011) with an average temperature of $85.5^{\circ} \mathrm{F}$. In the mountainous zones, at an elevation near $555 \mathrm{~m}$, the mean annual rainfall is about $2,155 \mathrm{~mm}$ at Cacaos-Orocovis NOAA weather station (National Oceanic and Atmospheric Administration, 2011). Monthly discharge at the Río Grande de Manatí (USGS station number 50038100 - Río Grande de Manatí at Highway 2, near Manatí, PR) varies between 152 and $707 \mathrm{~m}^{3} / \mathrm{s}$ (Figueroa-Alamo and others, 2004). Estimates of peak discharge during extreme events have been as high as $198,000 \mathrm{~m}^{3} / \mathrm{s}$ (September 10, 1996).

\section{Study Approach}

The analysis of Lago de Matrullas was designed to simulate the flood-wave elevation and the extent of the flood caused by dam failure under four hypothetical scenarios. The simulated scenarios include dam failure caused by precipitation and non-precipitation events. Hypothetical flood hydrographs used for three of the four dam failure scenarios were generated using the U.S. Army Corps of Engineers (USACE), Hydrologic Engineering Center's Hydrologic Modeling System (HEC-HMS) computer program (U.S. Army Corps of Engineers, 2010a). This model allows for simulation of rainfall-runoff processes for a drainage basin, based on its hydrologic properties and on a specified design scenario The hydrologic events considered in the analysis were a 6- and a 24-hour PMP event, as well as the flood resulting from a 100-year-recurrence, 24-hour rainfall event.

Dam-breach hydraulic analysis was performed using flood hydrographs generated from HEC-HMS for the Lago de Matrullas drainage basin, including downstream lateral inflows into the study reach (for example, Río Bauta, Río Cialitos, and Río Grande de Manatí). Inflow flood hydrographs for each of the three hydrologic storm events were used as input for the Hydrologic Engineering Center's River Analysis System (HEC-RAS) computer program. The unsteady component of the program was used to determine the water-surface profiles downstream from the Lago Matrullas Dam that could occur as a result of dam failure. The sunny day failure scenario was also incorporated in the hydraulic analysis by using base-flow estimates as input flow data. Dynamic wave routing was also performed through the reservoir, because bathymetric surveys for the reservoirs were available to develop the cross-section profiles needed within the reservoir.

\section{Hydrologic Study}

The HEC-HMS computer program (U.S. Army Corps of Engineers, 2010a) was used to determine the Lago de Matrullas subbasin hydrographs. Only those peak discharges resulting from the 6- and 24-hour PMP events and for the 100 -year flood with 24-hour duration are evaluated in this report.

\section{Modeling Approach}

The HEC-HMS program consists of three model components: the basin model, the meteorological model, and the control specifications. The basin model is used to represent the physical properties of the basin that characterize the runoff. The meteorological model uses either historical or hypothetical values of precipitation and evapotranspiration to determine the precipitation input and distribution into each subbasin. The control specifications are used to set the timespan of a simulation run.

The HEC-HMS basin model component is made up of a series of models that represent each component of the runoff process: runoff volumes, direct runoff (overland flow and interflow), base flow, and channel flow (U.S. Army Corps of Engineers, 2010a). The HEC-HMS model allows for the calculation of the runoff volume by estimating the precipitation losses and subtracting them from the total precipitation over the basin. These precipitation losses may include interception, infiltration, depression storage, evaporation, and (or) transpiration. The HEC-HMS basin model includes several alternatives to account for the precipitation losses: the initial and constant-rate loss model (also known as the initial- and uniform-rate loss model), the deficit and constant-rate loss model, the Soil Conservation Service (SCS) curve number (CN) loss model, and the Green-Ampt loss model. Each model computes the precipitation loss for each computation time interval and subtracts it from the mean-areal precipitation depth for that same interval. The remaining depth is referred to as precipitation excess. This precipitation depth is considered to be uniformly distributed over a basin area and, therefore, represents a runoff volume. 
Dam Failure Analysis for the Lago de Matrullas Dam, Orocovis, Puerto Rico

The direct runoff models, in turn, allow for the transformation of the excess precipitation into overland flow by using transforming methods, such as unit-hydrograph models and kinematic-wave models. HEC-HMS allows users to (1) perform channel routing to consider the effects of storage within the channels and (2) model water-control facilities, such as a reservoir or ponds (U.S. Army Corps of Engineers, 2000).

\section{Hydrographic Basin Delineation}

The boundaries of the Río Grande de Manatí hydrographic basin were obtained from the Watershed Boundary Database 1:20,000 for Puerto Rico (HUC12_NRCS_PRVI), and the basin is part of the 10-digit USGS Cataloging Unit 2101000202 (U.S. Geological Survey, 2002). For the dam-failure analysis of Lago de Matrullas, the surface area of the hydrographic basin encompasses about $453 \mathrm{~km}^{2}$ (fig. 2). The average slope of the hydrographic basin is approximately 35 percent and land-surface elevations within the basin exceed 1,000 $\mathrm{m}$ in some areas. For the analysis, the hydrographic basin was subdivided into nine subbasins to account for inflows from the Río Toro Negro, the Río Bauta, the Río Cialitos, and other desired outlet points (fig. 2). A brief description of each subbasin is presented in the Basin Parameters section herein.

\section{Runoff Losses}

For the hydrologic modeling approach used in this study, the primary source of precipitation losses involved infiltration. The SCS CN method was selected to account for precipitation losses (Mays, 2005). The method was developed by the NRCS (formerly Soil Conservation Service) and is widely used to transform rainfall into runoff. The runoff parameter used to determine the potential of runoff development is estimated as a function of land use, soil type, and soil antecedent moisture.

The $\mathrm{CN}$ is a dimensionless parameter used to describe runoff response and was calculated for the Río Grande de Manatí hydrographic basin by categorizing the soils within the basin into hydrologic soil groups (fig. 4). This hydrologic soil group classification was performed using digital maps from the Soil Survey Geographic (SSURGO) database published the Natural Resources Conservation Service (2013). A unique combination of the hydrologic soil groups and land-cover conditions from the Puerto Rico land cover layer, obtained from the National Land Cover Database for Puerto Rico (Natural Resources Conservation Service, 2003) and shown in figure 3 was applied to assign $\mathrm{CN}$ values from reference tables provided by NRCS (Mays, 2005). Table 2 shows the land cover and hydrologic groups categorized for the Río Grande de Manatí hydrographic basin and the $\mathrm{CN}$ assigned to each combination. A requirement of the $\mathrm{CN}$ method is to include the effects of antecedent moisture conditions in the hydrographic basin. The SCS CN method provides three antecedent moisture condition classes:

AMC I (dry conditions), AMC II (average conditions), and AMC III (saturated conditions). For the study, AMC II was selected as the antecedent moisture condition for runoff loss estimates. The composite values of $\mathrm{CN}$ for each subbasin included in the hydrologic model are summarized in the Basin Parameters section. 


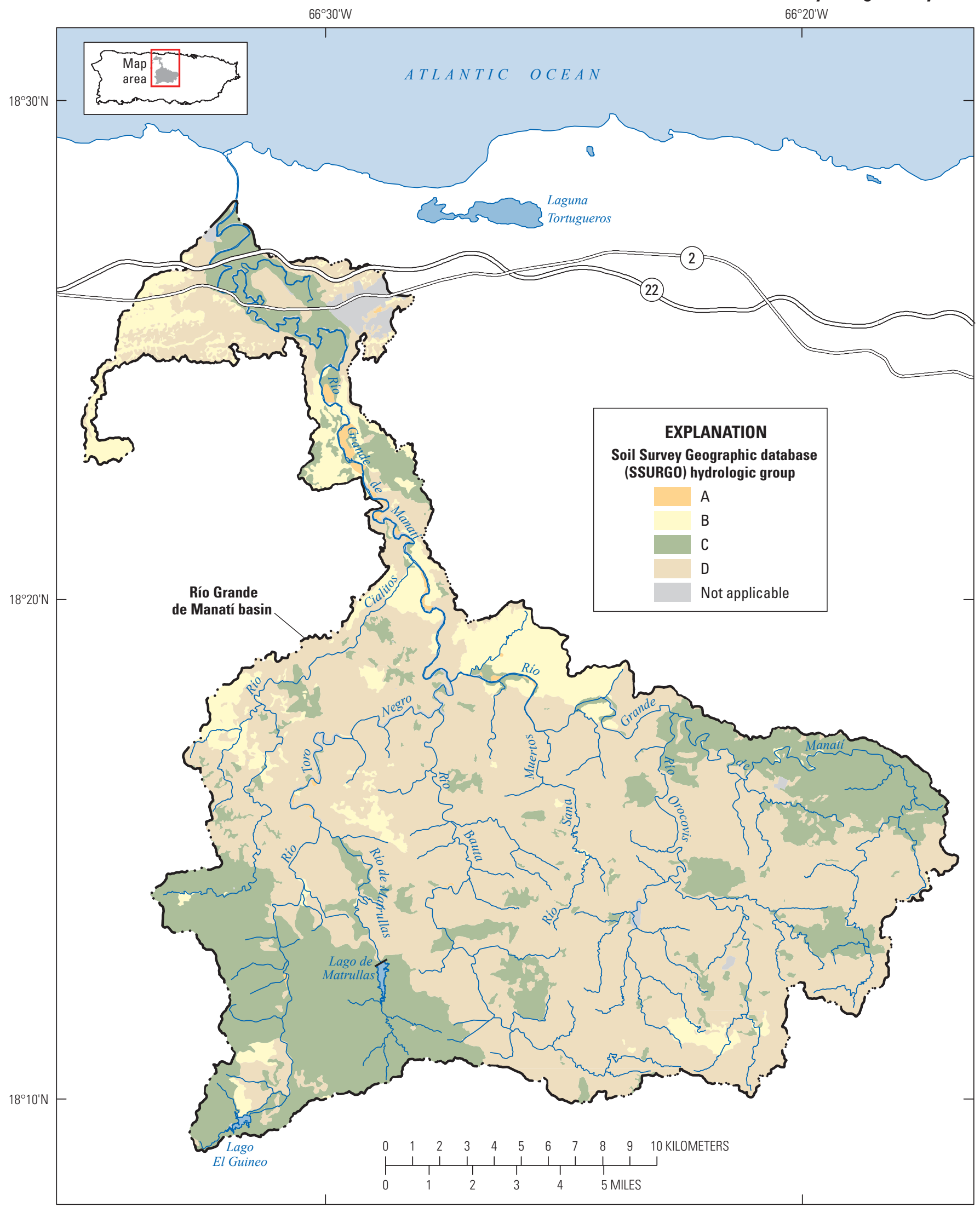

Base modified from U.S. Geological Survey 1:20,000-scale digital data Lambert Conformal Conic Projection Puerto Rico Datum, 1940 Adjustment

Figure 4. Hydrologic soil groups within the Río Grande de Manatí drainage basin. Hydrologic group data are from Natural Resources Conservation Service (2013). 
Table 2. Curve number used in the hydrologic analysis based on hydrologic groups and land cover data used for the dam failure analysis of Lago de Matrullas Dam, Orocovis, Puerto Rico.

\begin{tabular}{|lcccc}
\hline \multirow{2}{*}{ Land cover } & \multicolumn{4}{c}{ Hydrologic group } \\
\cline { 2 - 5 } & A & B & C & D \\
\hline Evergreen forest & 44 & 65 & 76 & 82 \\
\hline Herbaceous & 49 & 70 & 80 & 87 \\
\hline $\begin{array}{l}\text { Barren land } \\
\begin{array}{l}\text { Developed, } \\
\quad \text { low intensity }\end{array}\end{array}$ & 54 & 86 & 91 & 94 \\
\hline $\begin{array}{l}\text { Developed, } \\
\text { medium intensity }\end{array}$ & 61 & 70 & 80 & 85 \\
\hline $\begin{array}{l}\text { Developed, } \\
\text { high intensity }\end{array}$ & 89 & 92 & 94 & 95 \\
\hline $\begin{array}{l}\text { Developed, open } \\
\quad \text { space }\end{array}$ & 49 & 69 & 79 & 84 \\
\hline $\begin{array}{l}\text { Shrub/scrub } \\
\text { Cultivated crops }\end{array}$ & 67 & 67 & 77 & 83 \\
\hline
\end{tabular}

\section{Unit Hydrograph}

The traditional unit hydrograph technique was selected to transform the excess precipitation into direct runoff for each subbasin. The technique is a well-known, commonly used empirical method for relating the direct runoff to excess precipitation (Soil Conservation Service, 1986). As noted earlier, empirical (unit hydrograph) and conceptual methods are included in HEC-HMS for modeling direct runoff. The empirical models provide the user with a choice of methods that incorporate one of the following: a user-specified unit hydrograph, a Clark's unit hydrograph, a Snyder's unit hydrograph, and a SCS unit hydrograph.
The final option was selected as the unit hydrograph method used to determine the hydrographs used as inflow in the hydraulic model. The basic principles of the SCS unit hydrograph method establish that the peak discharge ( $q p$ ) is inversely related to the time to peak $(T p)$ and directly related to the drainage area. Ratios of the dimensionless unit hydrograph ordinates ( $t / \mathrm{T} p$ and $q / q p$ ) where $t$ is the time since the beginning of rainfall and $q$ is discharge at a given time, are provided by NRCS (Mays, 2005), and were used to generate the hydrograph based on the calculated peak discharge and time to peak flow. The input parameters required by the HEC-HMS model include the lag time and hydrographic basin area for each subbasin.

As stated by NRCS, the lag time is the time interval between the centroid of the mass of rainfall excess and the time to achieve the peak discharge (Mays, 2005), and is related to time of concentration using the following equation:

where

$$
T_{\text {lag }}=0.6 T_{\mathrm{c}}
$$

$$
\begin{aligned}
T_{\mathrm{c}} & =\text { time of concentration, in minutes; and } \\
T_{\text {lag }} & =\text { lag time, in minutes. }
\end{aligned}
$$

The Kirpich method (Gupta, 2001) was used to estimate $T_{\mathrm{c}}$ for each of the nine subbasins within the Río Grande de Manatí hydrographic basin. The estimation formula is expressed as follows:

$$
T_{\mathrm{c}}=0.02 L^{0.77} S^{-0.385}
$$

where

$$
\begin{aligned}
L= & \text { length of main channel, in meters; and } \\
S= & \text { slope, equal to } H / L \text {, where } H, \text { in meters, } \\
& \text { is the difference in elevation between the } \\
& \text { most remote point in the basin and the } \\
& \text { outlet. }
\end{aligned}
$$

The results of the lag time and time of concentration calculations for each subbasin are presented in the table 3 . 
Table 3. Basin parameters for the study of subbasins within the Río Grande de Manatí hydrographic basin used for the dam failure analysis of Lago de Matrullas Dam, Orocovis, Puerto Rico.

[HEC-HMS, Hydrologic Engineering Center, Hydrologic Modeling System; DA, drainage area; L, length of reach; H, height of dam; $T_{\mathrm{c}}$, time of concentration; $T_{\text {lag }}$, travel lag time; CN, curve number]

\begin{tabular}{|c|c|c|c|c|c|c|c|}
\hline $\begin{array}{l}\text { HEC-HMS } \\
\text { subbasin } \\
\text { identifier }\end{array}$ & Subbasin description & $\begin{array}{c}\text { DA, } \\
\text { in square } \\
\text { kilometers }\end{array}$ & $\begin{array}{c}\mathrm{L}, \\
\text { in } \\
\text { kilometers }\end{array}$ & $\begin{array}{l}\mathrm{H}, \\
\text { in meters }\end{array}$ & $\begin{array}{c}T_{c^{\prime}} \\
\text { in hours }\end{array}$ & $\begin{array}{c}T_{\text {lag' }} \\
\text { in hours }\end{array}$ & $\begin{array}{c}\text { CN, } \\
\text { unitless }\end{array}$ \\
\hline 1 & Lago de Matrullas Dam & 11.6 & 4.99 & 255 & 0.7 & 0.44 & 75.90 \\
\hline 2 & $\begin{array}{l}\text { Río Matrullas between Lago de Ma- } \\
\text { trullas Dam and Río Toro Negro }\end{array}$ & 9.61 & 8.37 & 510 & 1.03 & 0.62 & 80.70 \\
\hline 3 & Lago El Guineo Dam & 4.25 & 2.74 & 250 & 0.37 & 0.22 & 73.80 \\
\hline 5 & Río Bauta & 73.3 & 28.6 & 770 & 3.62 & 2.17 & 83.20 \\
\hline 6 & $\begin{array}{l}\text { Río Toro Negro between Río Matrullas } \\
\text { and Río Grande de Manatí }\end{array}$ & 22.7 & 14.6 & 455 & 2.04 & 1.22 & 81.90 \\
\hline 7 & $\begin{array}{l}\text { Río Grande de Manatí at confluence } \\
\text { with Río Toro Negro }\end{array}$ & 189.7 & 38.3 & 710 & 5.23 & 3.14 & 81.20 \\
\hline
\end{tabular}

\section{Channel Routing}

In large streams where channel storage may have an effect on the peak flow magnitude and time to peak flow, HEC-HMS provides flow routing techniques to account for the effects of channel storage on the runoff hydrograph (U.S. Army Corps of Engineers, 2000). As flood runoff moves through the channel, storage and energy losses may occur within the streams, and it is important to account for these losses when generating runoff hydrographs for subbasins that receive runoff from an upstream subbasin (McCuen, 2005). In the present study, channel routing was only applied between subbasins 3 and 4 to generate the inflow hydrograph from the Río Matrullas into Río Toro Negro (fig. 2). Channel-routing techniques were not applied to the remaining subbasins included in the breach analysis.

The Muskingum routing model (Mays, 2005) was used to simulate channel routing and storage. The model uses the flow continuity equation to account for the storage within the channel. Model parameters required by HEC-HMS to perform channel routing include the travel time, $K$, of the discharge wave through the routing reach and the inflow/ outflow dimensionless weighting factor, $x$. These parameters are commonly estimated using observed streamflow data. However, in the absence of recorded streamflow data, extensive literature describes use of the Muskingum routing method using estimated parameters. Carter and Godfrey (1960) suggest that for natural channels, 0.25 may be an appropriate value for $x$ and travel time, $K$, through the routing reach may be estimated by dividing the reach length by the mean channel velocity and a coefficient (1.44) based on the channel shape (Carter and Godfrey, 1960). Using the geometric characteristics of the reach, the mean velocity of the channel was estimated by applying Manning's equation (Gupta, 2001). The estimated travel time, $K$, through the routing channel between subbasins 3 and 4 was approximately 1.5 hours, assuming a mean channel velocity of 2 meters per second $(\mathrm{m} / \mathrm{s})$.

\section{Basin Parameters}

As discussed earlier in the Modeling Approach section, the SCS unit-hydrograph method was used to estimate the direct runoff at each subbasin outlet resulting from each of the simulated rainfall events. This method requires estimation of the following three basin parameters: $\mathrm{CN}, T_{c}$, and drainage area. Thus, for each subbasin included in the hydrologic analysis of the Río Grande de Manatí hydrographic basin, these basin parameters were determined and are shown in table 3. In the HEC-HMS model, general characteristics for Lago de Matrullas Dam and Lago de Guineo Dam were also included in the basin model. Stage-storage and outflow rating curves for both dams were obtained using the information provided by the Puerto Rico Electric Power Authority (1980a, b) and the USGS (Soler-López, 2003a, b). 


\section{Dam Failure Analysis for the Lago de Matrullas Dam, Orocovis, Puerto Rico}

\section{Rainfall}

The HEC-HMS meteorological model is the module in which the basin precipitation data are entered. The precipitation data may be observed rainfall from a historical event, a frequency-based hypothetical rainfall event, or it may be an event that represents the upper limit of precipitation possible at a given location. Rainfall data for the 6- and 24-hour PMP events included in the meteorological model for the Lago de Matrullas, and the other subbasins within the Río Grande de Manatí hydrographic basin, were obtained from U.S. Department of Commerce (1961). The report provides PMP amounts for durations of 1, 3, 6, 12, 18, and 24 hours. The point PMP, derived for each subbasin, was converted to basin-average amounts using the respective depth-area relations provided in the report. The computed rainfall depths were distributed in time and space to generate the direct runoff hydrographs for the selected frequency-based hypothetical storms. Precipitation depths for various durations within the storm event with a recurrence interval of 100 years and 24-hour duration were obtained from National Oceanic and Atmospheric Administration (2006). Table 4 shows the rainfall amounts for each subbasin and for each simulated storm.

The user-specified hyetograph method was selected to enter the rainfall data into the meteorological model for 6- and 24-hour PMP events. This method allows for defining the depth and temporal distribution of a hypothetical rainfall event (storm). The time distribution was derived following the chronological distribution indicated by the U.S. Department of Commerce (1961, p. 23-34). The FrequencyBased Hypothetical Storm method was used for the 100-year, 24-hour duration rainfall event simulation.

Table 4. Computed rainfall depths at each subbasin for the selected frequency-based hypothetical storms used for the dam failure analysis of Lago de Matrullas Dam, Orocovis, Puerto Rico.

[HEC-HMS, Hydrologic Engineering Center, Hydrologic Modeling System; PMP, probable maximum precipitation]

\begin{tabular}{|c|c|c|c|c|}
\hline \multirow[b]{2}{*}{$\begin{array}{l}\text { HEC-HMS } \\
\text { subbasin } \\
\text { identifier }\end{array}$} & \multirow[b]{2}{*}{ Subbasin description } & \multicolumn{3}{|c|}{ Computed rainfall, in millimeters } \\
\hline & & 24-hour PMP & 6-hour PMP & $\begin{array}{c}\text { 24-hour } \\
\text { 100-year rainfall } \\
\text { event }\end{array}$ \\
\hline 1 & Lago de Matrullas Dam & 1,390 & 828 & 599 \\
\hline 2 & Río Matrullas between Lago de Matrullas Dam and Río Toro Negro & 1,157 & 792 & 452 \\
\hline 3 & Lago El Guineo Dam & 1,397 & 851 & 630 \\
\hline 5 & Río Bauta & 1,317 & 792 & 467 \\
\hline 6 & Río Toro Negro between Río Matrullas and Río Grande de Manatí & 1,010 & 747 & 422 \\
\hline 7 & Río Grande de Manatí at confluence with Río Toro Negro & 1,015 & 648 & 376 \\
\hline 8 & Río Cialitos & 998 & 709 & 490 \\
\hline
\end{tabular}




\section{Flood Hydrographs and Peak Discharges}

The HEC-HMS computer program was used to determine the flood hydrographs and peak discharges resulting from 6- and 24-hour PMP events and for the 100-year, 24-hour duration rainfall events for the subbasins within the Río Grande de Manatí hydrographic basin (table 5). Results of the HEC-HMS simulations of flood hydrographs and peak discharges resulting from the selected frequency-based hypothetical storms are shown in appendix 1. The 6-hour PMP event generated a peak inflow of about $1,104 \mathrm{~m}^{3} / \mathrm{s}$ at Lago de Matrullas Dam and a peak inflow of about $550 \mathrm{~m}^{3} / \mathrm{s}$ at Lago El Guineo Dam. The 24-hour PMP event produced peak inflows of $1,032 \mathrm{~m}^{3} / \mathrm{s}$ and $414 \mathrm{~m}^{3} / \mathrm{s}$ at Lago de Matrullas Dam and Lago El Guineo Dam, respectively. The 100-year-recurrence, 24-hour rainfall event simulations resulted in peak inflow of about $418 \mathrm{~m}^{3} / \mathrm{s}$ at Lago de Matrullas Dam and about $216 \mathrm{~m}^{3} / \mathrm{s}$ at Lago El Guineo Dam.

The hydrologic analysis results indicated that during the 6- and 24-hour PMP events, Lago de Matrullas Dam experienced overtopping. The hydrologic analysis assumed that the dam would not fail during the flood events. Model results also indicated that the morning-glory type spillway has the capacity to manage the flood resulting from the 100-year recurrence, 24-hour rainfall event. However, during the 6- and 24-hour PMP events, the morning-glory type spillway could be discharging at its maximum capacity of $425 \mathrm{~m}^{3} / \mathrm{s}$. The hydrologic analysis indicated that the 6-hour PMP event had larger intensity and produced a higher peak discharge than 24-hour PMP event. The maximum precipitation flood, which is the flood resulting from the more severe combination of hydrologic and meteorological conditions (Federal Emergency Management Agency, 2013), is about 1,104 $\mathrm{m}^{3} / \mathrm{s}$ for the Lago Matrullas dam drainage area. Table 6 shows the peak inflow and outflow (through the morning-glory spillway) from Lago de Matrullas Dam for the simulated events.

To approximate the flow discharged during overtopping, the top of the dam was analyzed as a weir structure. The outflow rating curve included in the hydrologic model was extended beyond the design height of the spillway to account for the water overtopping the dam. The results indicated that for the 6- and 24- hour PMP events, the outflow from Lago de Matrullas Dam, considering the overflow, was 661 and $907 \mathrm{~m}^{3} / \mathrm{s}$, respectively.

Table 5. Peak discharges at each subbasin resulting from simulated rainfall events used for the dam failure analysis of Lago de Matrullas Dam, Orocovis, Puerto Rico.

[HEC-HMS, Hydrologic Engineering Center, Hydrologic Modeling System; PMP, probable maximum precipitation; $\mathrm{m}^{3} / \mathrm{s}$, cubic meter per second; $\mathrm{ft}^{3} / \mathrm{s}$ cubic foot per second]

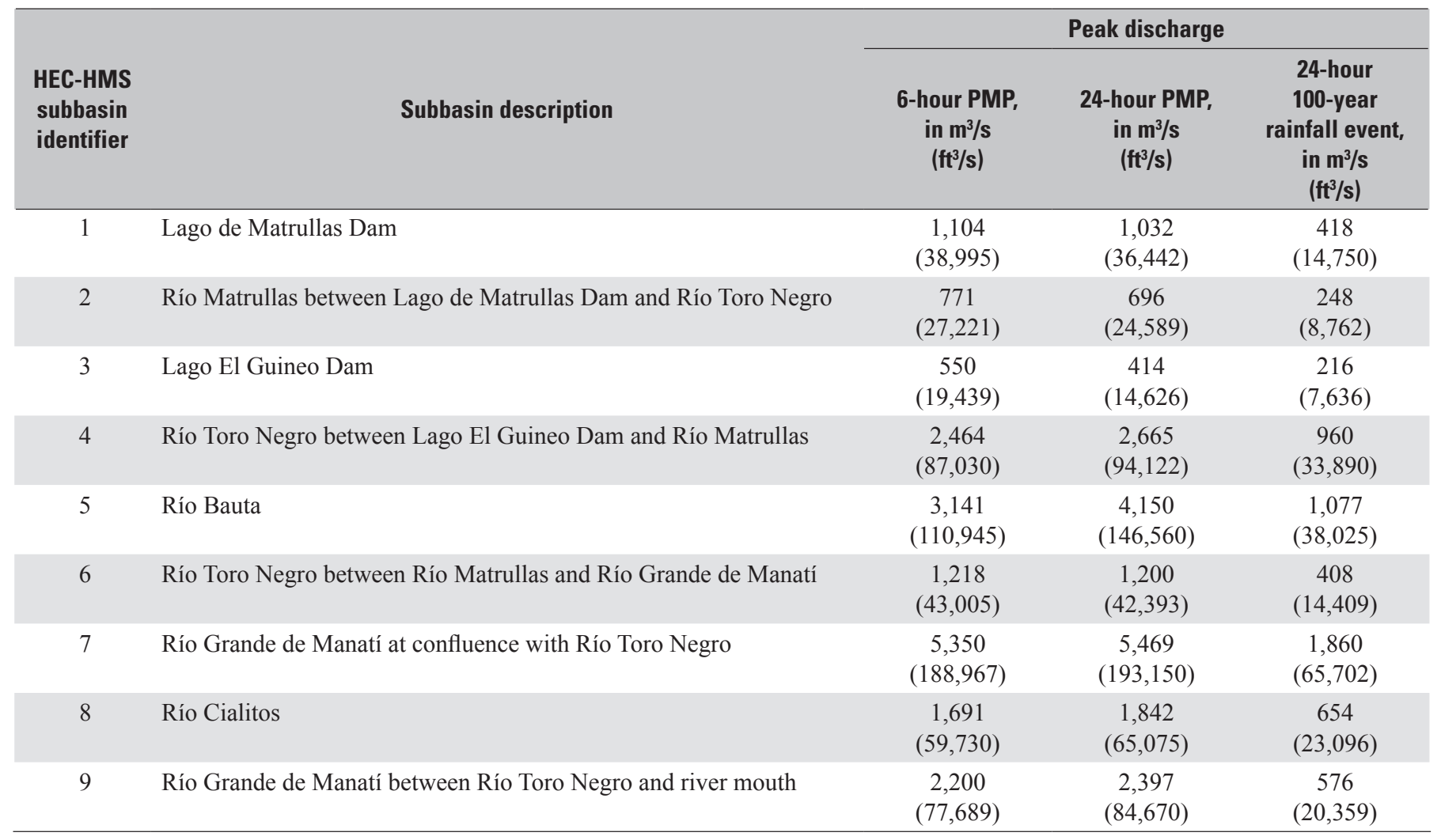


Table 6. Peak inflow and outflow discharge of Lago de Matrullas Dam, Orocovis, Puerto Rico, for the simulated rainfall events.

$\left[\mathrm{m}^{3} / \mathrm{s}\right.$, cubic meter per second; $\mathrm{ft}^{3} / \mathrm{s}$, cubic foot per second; PMP, probable maximum precipitation]

\begin{tabular}{|ccc}
\hline $\begin{array}{c}\text { Simulated } \\
\text { rainfall event }\end{array}$ & $\begin{array}{c}\text { Peak inflow } \\
\text { discharge, } \\
\text { in } \mathbf{~ m}^{3} / \mathbf{s} \\
\left(\mathbf{f t}^{3} / \mathbf{s}\right)\end{array}$ & $\begin{array}{c}\text { Peak outflow } \\
\text { discharge, } \\
\text { in } \mathbf{~ m}^{3} / \mathbf{s} \\
\left(\mathbf{f t}^{3} / \mathbf{s}\right)\end{array}$ \\
\hline 6-hour PMP & 1,104 & 425 \\
& $(38,995)$ & $(15,000)$ \\
24-hour PMP & 1,032 & 425 \\
& $(36,442)$ & $(15,000)$ \\
24-hour 100-year & 418 & 359 \\
rainfall & $(14,750)$ & $(12,679)$ \\
\hline
\end{tabular}

\section{Hydraulic Study}

The purpose of the hydraulic analysis is to assess the potential hazard to human life and property downstream from the Lago de Matrullas Dam associated with hypothetical dam failure during floods from 6- and 24-hour PMP events, a 100-year flood, and non-flood conditions (sunny-day failure). The HEC-RAS computer program (U.S. Army Corps of Engineers, 2010b) was used to determine flood level, flood peak, and time to peak following dam failure at selected locations downstream from the dam for each simulated breach condition.

\section{Modeling Approach}

The HEC-RAS unsteady flow analysis uses a breach model to simulate dam failure. The hydraulic model requires the following input data: the stream cross section, hydraulic structure, dam and reservoir geometry, inflow hydrographs, dam breach parameters, and a Manning's roughness coefficient, $n$. Unsteady flow simulations require the user to define conditions at all external boundaries of the system and at internal locations where inflows enter (or exit) the system. The manner by which reaches are joined or connected together in the system also must be specified. Hence, dam breach flows under hydrologic-based and sunny day conditions are downstream-routed through the river system.

The breach model uses an inline weir to simulate the dam embankment and the breach shape. A simple temporal and geometrical description of the breach is used to simulate how the breach progresses during the failure. The outflow hydrograph routed through the reservoir, as a result of the breach, is computed using a broad-crested weir flow approximation that includes the effects of submergence from downstream tail-water depths. Dynamic wave routing is used to attenuate the inflow hydrograph within the reservoir. The computer model solves the one-dimensional unsteady flow equations using the four-point implicit scheme, also known as the box scheme. The implicit finite difference scheme results in a system of nonlinear algebraic equations. To avoid the nonlinear solution, the HEC-RAS application incorporates into its computer routine a technique developed by Preissmann (as reported by Liggett and Cunge, 1975) and Chen (1973) for linearizing the equations. Downstream routing through the channel includes the hydrograph resulting from the failure of the dam, as well as from the lateral inflows of tributaries that drain into the study reach.

In the HEC-RAS model, the hydraulic system was subdivided into three hydraulic reaches: the Río Matrullas lower reach, the Río Toro Negro lower reach, and the Río Grande de Manatí lower reach (fig. 5). Each study reach was analyzed in separate models; consequently, the outflow hydrograph resulting from the hydraulic model of the Río Matrullas lower reach was used as the inflow hydrograph to the Río Toro Negro lower reach. Similarly, the outflow hydrograph of the Río Toro Negro lower reach corresponded to the inflow hydrograph for the Río Grande de Manatí lower reach. Contributions from other streams discharging into each hydraulic reach were also included as lateral inflows. 


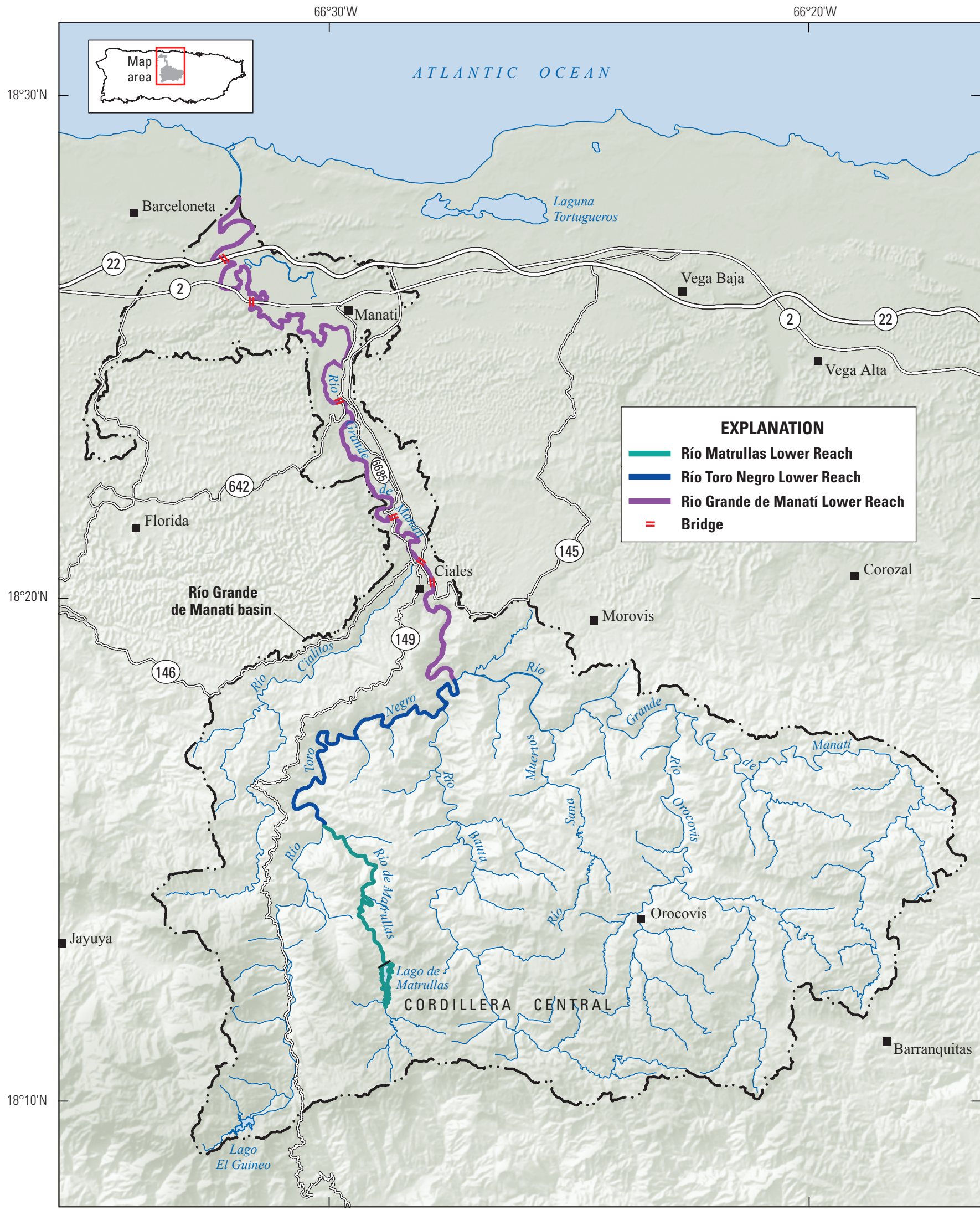

Base modified from U.S. Geological Survey 1:20,000-scale digital data Lambert Conformal Conic Projection Puerto Rico Datum, 1940 Adjustment Shaded relief from U.S. Geological Survey National Elevation Dataset

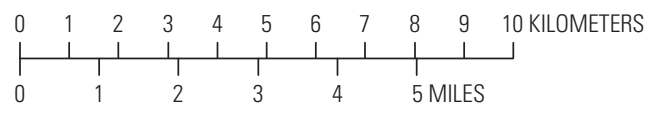

Figure 5. Hydraulic system simulated as part of the dam failure analysis for the Lago de Matrullas Dam, Orocovis, Puerto Rico. 


\section{Geometric Data}

A total of 57 cross sections were included in the hydraulic analysis to define the natural channel geometry of the stream reaches. A total of 16 cross sections defined the geometry of the lower reach of Río Matrullas, 12 cross sections defined the geometry of the lower reach of Río Toro Negro, and 29 cross sections defined the geometry of the lower reach of Río Grande de Manatí. The cross-section data were generated from the 1:20,000 USGS topographic quadrangles for Barceloneta, Barranquitas, Ciales, Corozal, Florida, Jayuya, Manatí, Orocovis, and Vega Alta. The lower reach of the Río Grande de Manatí also included cross-section data obtained from the Flood Insurance Study (Federal Emergency Management Agency, 2009; Carmen Delgado, Federal Emergency Management Agency, written commun., 2014) for the Río Grande de Manatí hydrographic basin.

The lower reach of the Río Matrullas is about $9.4 \mathrm{~km}$ long and includes the reservoir and the segment downstream between the Lago de Matrullas Dam and the confluence of Río Matrullas and lower reach of the Río Toro Negro. The Lago de Matrullas reservoir bottom was defined using nine cross sections. These cross sections were obtained from a bathymetric survey of Lago de Matrullas conducted by the USGS in December 2001 (Soler-López, 2003a). A cross section defining the Lago de Matrullas Dam structure was obtained from engineering construction drawings provided by PREPA (Puerto Rico Electric Power Authority, 1980a). The Manning's roughness coefficient ( $\mathrm{n}$ value) selected for the reservoir segment was set to 0.040 . Along the lower reach length below the dam, the streambed elevation drops about $500 \mathrm{~m}$ and $\mathrm{n}$ values range from 0.065 to 0.090 .

The hydraulic system including the lower reach of the Río Toro Negro is about $14.5 \mathrm{~km}$ long and extends from the Río Matrullas-Río Toro Negro confluence to the Río Toro Negro-Río Grande de Manatí confluence. An n value of 0.045 was assigned for the main channel and $\mathrm{n}$ values from 0.065 to 0.070 were assigned for the channel banks.

The lower reach of the Río Grande de Manatí is about $22.0 \mathrm{~km}$ long and extends from the junction with the Río Toro Negro downstream to the town of Barceloneta. The $\mathrm{n}$ values for the lower reach of the Río Grande de Manatí vary widely, from 0.04 to 0.045 for the main channel, and from 0.07 to 0.10 for the flood plain. All of the $\mathrm{n}$ values were assigned on the basis of field reconnaissance (March, 2014) and interpretation of aerial photographs (U.S. Army Corp of Engineers, 2010c). Barnes (1967) and Mays (2005) were used as references in the selection of the $\mathrm{n}$ values for the cross sections.

Hydraulic structures, such as bridges, were included in the lower reach of Río Grande de Manatí. A total of six bridges were incorporated in the analysis and their geometric data were obtained from the Puerto Rico Highway and Transportation Authority (Dr. Manuel Coll, Bridge Engineering Office, oral commun., 2014). Additional geometric data for the area were obtained from the hydrologic-hydraulic study used for the Flood Insurance Study (Carmen Delgado, Federal
Emergency Management Agency, written commun., 2014) published in 2009 for the study area. Additionally, a levee located near the town of Barceloneta (Federal Emergency Management Agency, 2009) was included in the model by using the levee option available in the HEC-RAS model.

\section{Boundary Conditions, Reach Connections, and Initial Conditions}

The upstream boundary conditions of the Río Matrullas lower reach correspond to the inflow hydrograph determined by the HEC-HMS model for each of the three simulated rainfall events. For the Río Toro Negro lower reach, the upstream boundary conditions correspond to the outflow hydrograph resulting from the Río Matrullas lower reach simulation. Similarly, the upstream boundary conditions of the Río Grande de Manatí lower reach are obtained from the outflow hydrographs that resulted from the simulation of the Río Toro Negro lower reach. The downstream boundary conditions for the three study reaches were assumed to represent normal depth (defined as a condition in which the slope of the water surface and the bottom of the channel are equal).

Internal boundary conditions, also known as lateral inflows, were used for the inflows from the upper reach of the Río Toro Negro, the Río Bauta, the Río Cialitos, and the upper reach of the Río Grande de Manatí (fig. 5). The lateral inflows were determined by the HEC-HMS model for each of the simulated rainfall events.

To avoid model instability, the HEC-RAS model provides an alternative simulation that uses "hot start" initial conditions from a previous simulation, with all inflow hydrographs set to a constant flow, and the downstream boundary conditions set as a stage hydrograph from a high tail-water elevation to normal depth. The hot start simulation prevents unsteady flow simulation issues resulting from channels becoming dry during the simulation. Typical values for upstream boundary conditions in the hot start simulation are based on observed base-flow data or a constant flow estimated using 1 to 10 percent of the peak discharge value of the simulated storm (Chris Goodell, West Consultant Inc., oral commun., 2014). For the Lago de Matrullas reach, the upstream boundary condition used in the hot start simulation specified a constant flow equal to 4 percent of the peak flow value calculated in the hydrologic study for the 6-hour PMP event. For the internal boundary conditions (lateral inflows) included along the three hydraulic reaches, a constant flow equal to 1 percent of the peak flow value estimated from the 100-year, 24-hour rainfall event for each subbasin was used.

\section{Breach Parameters and Failure Criteria}

The parameters considered most critical in any analysis of dam breaching are the maximum size of the breach opening and the breach formation time. Embankment dam breaches are typically assumed to be approximately trapezoidal in shape. 
The breach geometry can be described in terms of breach height, average breach width, and breach side slope. The slope of the breach invert is assumed to be horizontal in the direction of flow. The breach formation time is the elapsed time between the first breaching of the upstream face of the dam and the complete formation of the breach. These parameters describe the breach geometry to the extent needed to compute flow rates through the breach, assuming the discharge characteristics of a broad-crested weir.

Several methods can be used to estimate dam breach parameters and they are classified into three main groups: physically based erosion methods, parametric regression equations, and predictor regression equations. The first group predicts the breach development and outflow hydrograph based on physical properties, such as stage-storage relationships, soil properties in the dam, and dam dimensions. The second group is based on the analysis of dam-breach case studies and uses empirical equations developed for estimating the breach width and time to failure. The third group involves regression equations obtained using case-study information to estimate breach peak discharges (Federal Emergency Management Agency, 2013). The U.S. Bureau of Reclamation, as well as others who study dam-breaching, has developed multiple empirical relations to estimate breach parameters. For dam failure analysis of Lago de Matrullas, relations proposed by the U.S. Bureau of Reclamation (1998) were selected to estimate the breach width and time of failure. A sensitivity analysis was conducted to evaluate breach peak discharge variability when changing breach parameters. The following equations were used to estimate the dam breach parameters:

$$
B=3 * h w,
$$

and

$$
t_{\mathrm{f}}=0.011 * B,
$$

where

$$
\begin{aligned}
B \quad= & \text { average dam-breach width, in meters; } \\
h w \quad & \text { height of water above the dam breach invert } \\
& \text { at time of failure, in meters; and } \\
t_{\mathrm{f}} \quad & \text { time of failure since the beginning of the } \\
& \quad \text { upstream face breach, in hours. }
\end{aligned}
$$

Assuming the dam will fail once the water-surface elevation exceeds the top of the dam $(748.58 \mathrm{~m})$ by $0.5 \mathrm{~m}$ and the final elevation of the breach is at $723.26 \mathrm{~m}, h w$ is $25.82 \mathrm{~m}$. Using relations developed by the U.S. Bureau of Reclamation, the average dam-breach width is $77.46 \mathrm{~m}$ and the time of failure is 0.85 hour. The HEC-RAS model uses a trapezoidal section to simulate the final form of the dam breach. The breach side slopes were assumed to have a side slope of 0.5 , and the final bottom width was about $64.9 \mathrm{~m}$.

Dam-breach parameters were used to simulate dam failure (table 7). The Lago de Matrullas Dam failure analysis included consideration of piping and overtopping, and failure criteria assumed that the reservoir was emptied during the simulation. Dam failure caused by overtopping was selected for the 6- and 24-hour PMP breach scenarios because the results of the hydrologic study indicated that overtopping occurred during simulations. Dam breach caused by piping was selected for the breach scenarios during sunny day conditions and during hydrologic conditions associated with the 100-year, 24-hour duration rainfall event. For overtopping failure, the threshold to initiate the breach processes was set to a water-surface elevation that did not exceed the top of the dam by more than $0.5 \mathrm{~m}(749.08 \mathrm{~m})$. For the piping failure condition, the breach was initiated when the peak discharge for each simulated storm reached the dam (worst-case scenario). The breach for the sunny day simulation was initiated when the water-surface elevation in the reservoir was about $743.5 \mathrm{~m}$ (morning-glory spillway invert).

Table 7. Breach parameters used for the dam failure analysis of Lago de Matrullas Dam, Orocovis, Puerto Rico.

[PMP, probable maximum precipitation]

\begin{tabular}{ll}
\hline \multicolumn{1}{c}{ Breach parameter } & \multicolumn{1}{c}{ Value } \\
\hline Center station, in meters (feet) & $213.35(700)$ \\
\hline $\begin{array}{l}\text { Final bottom width, in meters (feet) } \\
\text { Final bottom elevation, in meters } \\
\text { (feet) above mean sea level }\end{array}$ & $72.91(213)$ \\
\hline $\begin{array}{l}\text { Left side slope } \\
\text { Right side slope }\end{array}$ & 0.5 \\
\hline $\begin{array}{l}\text { Full formation time, in hours } \\
\text { Failure mode for 6-hr and 24-hr PMP }\end{array}$ & 0.5 \\
\hline $\begin{array}{l}\text { Failure mode for sunny day and } \\
\text { 100-year flood }\end{array}$ & Piping \\
\hline $\begin{array}{l}\text { Piping coefficient } \\
\text { Initial piping elevation, in meters } \\
\quad \text { feet) }\end{array}$ & 0.85 \\
\hline $\begin{array}{l}\text { Trigger elevation for 6-hr and } \\
\text { 24-hr PMP, in meters (feet) }\end{array}$ & $737.58(2,420)$ \\
\hline $\begin{array}{l}\text { Trigger elevation for sunny day, in } \\
\text { meters (feet) above mean sea level }\end{array}$ & $743.5(2,439.43)$ \\
\hline \begin{tabular}{l} 
Trigger time for 100-year flood \\
\hline
\end{tabular} & Time to peak of inflow \\
\hline
\end{tabular}

\section{Dam Failure Simulations and Results}

Results are presented only for selected locations along the lower reach of the Río Grande de Manatí, even though the flood wave was downstream-routed through the lower reach of Río Matrullas, Río Toro Negro and Río Grande de Manatí (fig. 5). The results of the dam failure analysis during the 6- and 24-hour PMP events, the 100-year recurrence, 24-hour rainfall event, and sunny day conditions are included in tables $8-11$. 


\section{Dam Failure Under Probable Maximum} Precipitation Conditions

The peak discharges produced by dam failure at the toe of Lago de Matrullas Dam were computed as 3,149.33 m³ for the 6-hour PMP event and 3,604.7 $\mathrm{m}^{3} / \mathrm{s}$ for the 24-hour PMP event. Along the Río Grande de Manatí lower reach and about $0.6 \mathrm{~km}$ upstream of the PR-145 bridge, the peak discharge was $12,995.44 \mathrm{~m}^{3} / \mathrm{s}$ for the 6-hour PMP event and $14,800.87 \mathrm{~m}^{3} / \mathrm{s}$ for the 24-hour PMP event (tables 8,9 , respectively). Near the town of Barceloneta at the PR-22 bridge, the peak discharge was $12,781.07 \mathrm{~m}^{3} / \mathrm{s}$ for the 6-hour PMP event and 14,549.13 $\mathrm{m}^{3} / \mathrm{s}$ for the 24-hour PMP event. The maximum water-surface profiles resulting from these flood events along the lower reach of the Río Grande de Manatí indicate overtopping of the PR-6685, PR-149, PR-642 and PR-145 bridges (fig. 6).

Table 8. Results for the 6-hour probable maximum precipitation at selected cross sections along the lower reach of the Río Grande de Manatí for the dam failure analysis of Lago de Matrullas Dam, Orocovis, Puerto Rico.

[Refer to plate 1 for location of cross sections. km, kilometer]

\begin{tabular}{|c|c|c|c|c|c|}
\hline $\begin{array}{l}\text { Section } \\
\text { number }\end{array}$ & Nearby landmark & $\begin{array}{c}\text { Distance } \\
\text { from dam, } \\
\text { in kilometers }\end{array}$ & $\begin{array}{l}\text { Peak discharge, } \\
\text { in cubic meters } \\
\text { per second } \\
\text { (in cubic feet } \\
\text { per second) }\end{array}$ & $\begin{array}{l}\text { Peak elevation, } \\
\text { in meters } \\
\text { (in feet) }\end{array}$ & $\begin{array}{l}\text { Time to peak } \\
\text { in hours }\end{array}$ \\
\hline 13 & $\begin{array}{l}2.7 \mathrm{~km} \text { downstream of confluence between } \\
\text { Río Toro Negro and Río Grande de Manatí }\end{array}$ & 24.7 & $\begin{array}{l}13,231.00 \\
(467,317)\end{array}$ & $\begin{array}{c}64.06 \\
(210.19)\end{array}$ & 0.5 \\
\hline 9 & At PR-6685 bridge & 32.7 & $\begin{array}{l}14,286.88 \\
(504,610)\end{array}$ & $\begin{array}{c}42.46 \\
(139.3)\end{array}$ & 1 \\
\hline 7 & $1.7 \mathrm{~km}$ upstream from PR-642 bridge & 36.8 & $\begin{array}{l}13,963.64 \\
(493,194)\end{array}$ & $\begin{array}{c}30.52 \\
(100.13)\end{array}$ & 1.25 \\
\hline 5 & $1.8 \mathrm{~km}$ south of Manatí town & 41.5 & $\begin{array}{l}13,688.49 \\
(483,475)\end{array}$ & $\begin{array}{c}19.37 \\
(63.56)\end{array}$ & 1.5 \\
\hline 1.4 & Near town of Barceloneta at PR-22 bridge & 53.4 & $\begin{array}{l}12,781.07 \\
(451,425)\end{array}$ & $\begin{array}{c}10.41 \\
(34.15)\end{array}$ & 2.75 \\
\hline
\end{tabular}


Table 9. Results for the 24-hour probable maximum precipitation at selected cross sections along the lower reach of the Río Grande de Manatí for the dam failure analysis of Lago de Matrullas Dam, Orocovis, Puerto Rico.

[Refer to plate 1 for location of cross sections. km, kilometer]

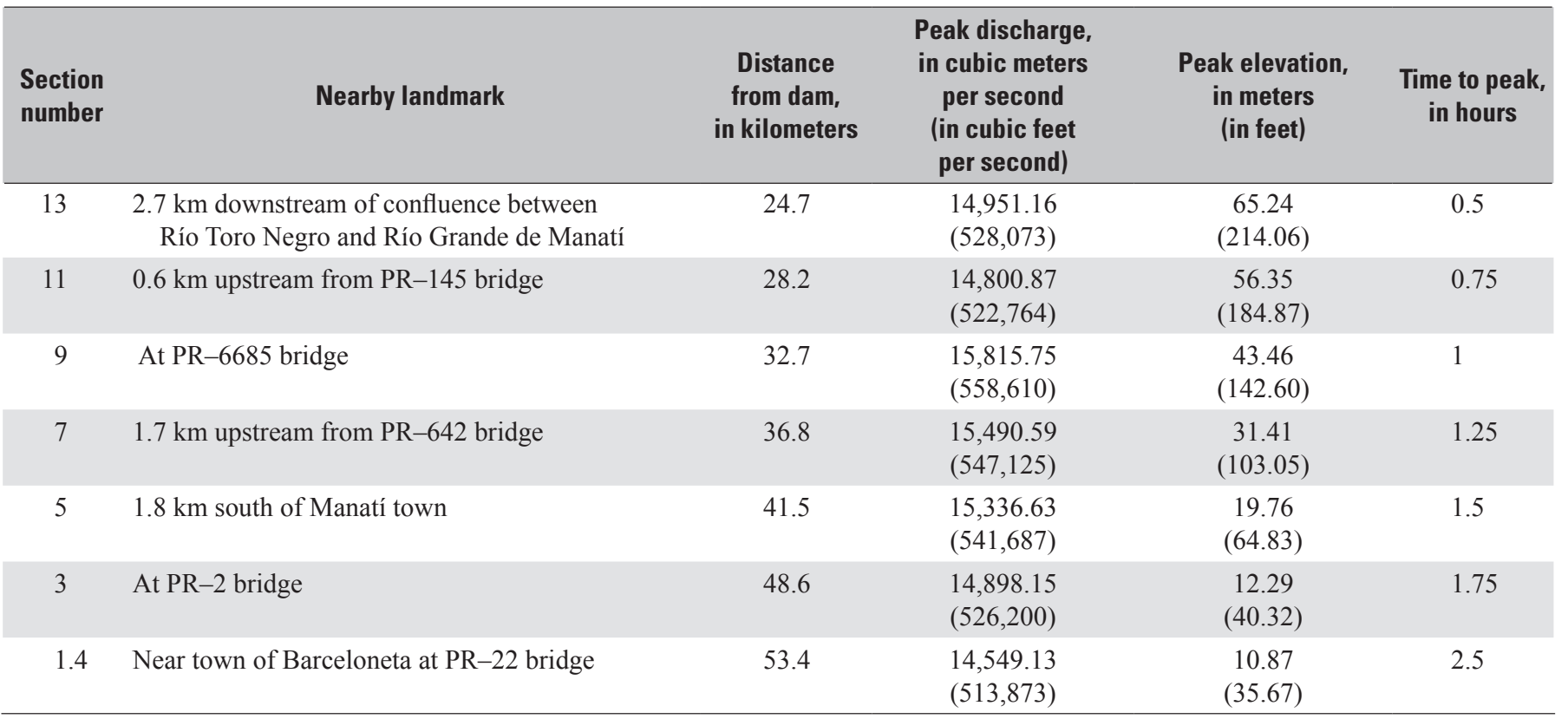

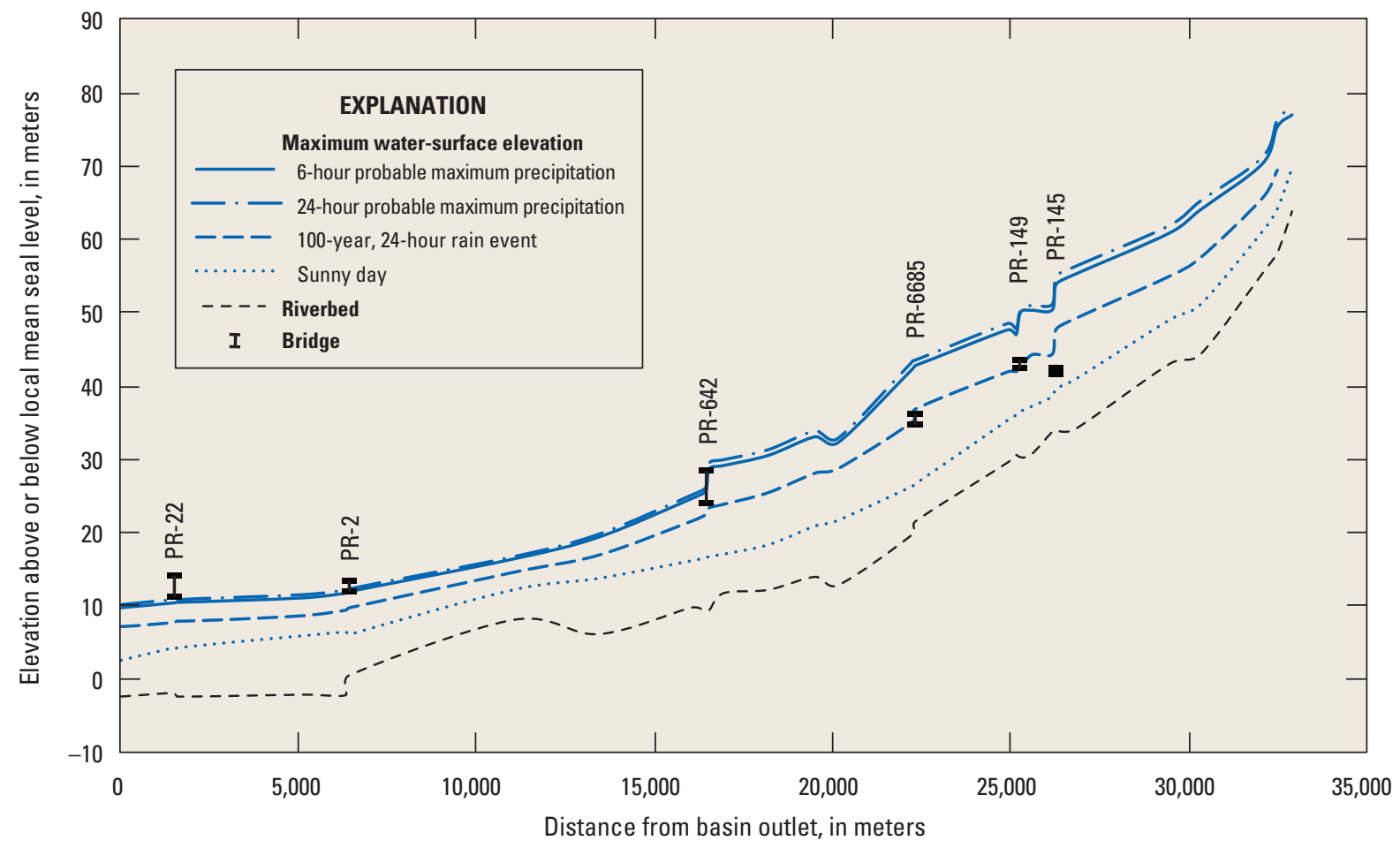

Figure 6. Maximum water-surface profile along the lower reach of the Río Grande de Manatí for the 6-hour probable maximum precipitation (PMP) for the dam failure analysis of the Lago de Matrullas Dam, Orocovis, Puerto Rico. 


\section{Dam Failure Under 100-Year Flood Conditions}

The dam failure for the 100-year-recurrence, 24-hour rainfall event (100-year flood) was initiated when the peak inflow discharge reached the dam and the reservoir pool elevation was $745.38 \mathrm{~m}$. Dam failure analysis results were summarized for selected cross sections (table 10). At the toe of Lago de Matrullas Dam, the computed peak discharge produced by the dam failure was $2,103.12 \mathrm{~m}^{3} / \mathrm{s}$. Along the Río Grande de Manatí lower reach, a peak discharge of $5,545.48 \mathrm{~m}^{3} / \mathrm{s}$ was estimated near the PR-145 bridge (about $0.6 \mathrm{~km}$ upstream). At the PR-22 bridge near the town of Barceloneta, the peak discharge was $4,834.68 \mathrm{~m}^{3} / \mathrm{s}$. The maximum water-surface profile resulting from this flood event along the lower reach of the Río Grande de Manatí indicates overtopping of the PR-6685, PR-149, and PR-145 bridges (fig. 6).

\section{Dam Failure Under Sunny Day Conditions}

Failure of the Lago de Matrullas Dam under sunny day conditions was initiated at a reservoir pool elevation of about $743.5 \mathrm{~m}$. Dam failure analysis results were summarized at selected cross sections (table 11). The estimated peak discharge just downstream from the Lago de Matrullas Dam was $1,695.91 \mathrm{~m}^{3} / \mathrm{s}$. Along the Río Grande de Manatí lower reach, the peak discharge was $1,109.09 \mathrm{~m}^{3} / \mathrm{s}$ about $0.6 \mathrm{~km}$ upstream of the PR-145 bridge. Estimated discharge was $387.72 \mathrm{~m}^{3} / \mathrm{s}$ near the town of Barceloneta (at the PR-22 bridge). The maximum water-surface profile along the lower reach of the Río Grande de Manatí indicates no bridge overtopping (fig. 6).

\section{Sensitivity Analysis}

The breach parameters used for the dam failure analysis of Lago de Matrullas were varied to determine their effect on breach peak discharge. For both dam failure types (piping and overtopping), the base-case scenario considered a final breach width and breach formation time of $64.92 \mathrm{~m}$ and 0.85 hour, respectively. These breach parameters were modified for the simulated hydrologic condition of the 6-hour PMP event. Overtopping and piping failures were evaluated by varying the breach final bottom width and breach formation time, respectively (tables 12, 13).

Breach simulation results indicate that the breach formation time has a greater effect in the breach peak discharge at the dam than the final bottom width of the breach (table 14). For both piping and overtopping dam failure, peak discharge changed by more than 10 percent when the breach formation time was reduced compared to the base-case scenario, which used a breach formation time of 0.85 hour. Comparisons made between overtopping and piping failure indicated that for the dam breach scenario during a 6-hour PMP event, peak discharge at the dam was $3,149.33 \mathrm{~m}^{3} / \mathrm{s}$ during overtopping failure and $3,200.6 \mathrm{~m}^{3} / \mathrm{s}$ during piping failure (table 14), a difference of only 1.6 percent. Sensitivity analysis of modifications to the side slope of the breach were also conducted but are not presented herein because this parameter did not substantially affect peak discharge at the dam.

Table 10. Results for the 24-hour, 100-year rainfall event at selected cross sections along the lower reach of the Río Grande de Manatí for the dam failure analysis of Lago de Matrullas Dam, Orocovis, Puerto Rico.

[Refer to plate 1 for location of cross sections. $\mathrm{km}$, kilometer]

\begin{tabular}{|c|c|c|c|c|c|}
\hline $\begin{array}{l}\text { Section } \\
\text { number }\end{array}$ & Nearby landmark & $\begin{array}{c}\text { Distance } \\
\text { from dam, } \\
\text { in kilometers }\end{array}$ & $\begin{array}{l}\text { Peak discharge, } \\
\text { in cubic meters } \\
\text { per second } \\
\text { (in cubic feet } \\
\text { per second) }\end{array}$ & $\begin{array}{l}\text { Peak elevation, } \\
\text { in meters } \\
\text { (in feet) }\end{array}$ & $\begin{array}{l}\text { Time to peak } \\
\text { in hours }\end{array}$ \\
\hline 13 & $\begin{array}{l}2.7 \mathrm{~km} \text { downstream of confluence between } \\
\text { Río Toro Negro and Río Grande de Manatí }\end{array}$ & 24.7 & $\begin{array}{l}5,776.75 \\
(204,034)\end{array}$ & $\begin{array}{c}57.5 \\
(188.66)\end{array}$ & 0.75 \\
\hline 9 & At PR-6685 bridge & 32.7 & $\begin{array}{l}5,894.85 \\
(208,205)\end{array}$ & $\begin{array}{c}35.21 \\
(115.52)\end{array}$ & 1.25 \\
\hline 7 & $1.7 \mathrm{~km}$ upstream from PR-642 bridge & 36.8 & $\begin{array}{l}5,710.47 \\
(201,693)\end{array}$ & $\begin{array}{c}25.34 \\
(83.15)\end{array}$ & 1.5 \\
\hline 5 & $1.8 \mathrm{~km}$ south of Manatí town & 41.5 & $\begin{array}{c}5,473.96 \\
(193,339)\end{array}$ & $\begin{array}{c}16.93 \\
(55.54)\end{array}$ & 2 \\
\hline 1.4 & Near town of Barceloneta at PR-22 bridge & 53.4 & $\begin{array}{c}4,834.68 \\
(170,760)\end{array}$ & $\begin{array}{c}7.74 \\
(25.40)\end{array}$ & 3.0 \\
\hline
\end{tabular}


Table 11. Results for sunny day conditions at selected cross sections along the lower reach of the Río Grande de Manatí for the dam failure analysis of Lago de Matrullas Dam, Orocovis, Puerto Rico.

[Refer to plate 1 for location of cross sections. km, kilometer]

\begin{tabular}{|c|c|c|c|c|c|}
\hline $\begin{array}{l}\text { Section } \\
\text { number }\end{array}$ & Nearby landmark & $\begin{array}{c}\text { Distance } \\
\text { from dam, } \\
\text { in kilometers }\end{array}$ & $\begin{array}{l}\text { Peak discharge, } \\
\text { in cubic meters } \\
\text { per second } \\
\text { (in cubic feet } \\
\text { per second) }\end{array}$ & $\begin{array}{l}\text { Peak elevation, } \\
\text { in meters } \\
\text { (in feet) }\end{array}$ & $\begin{array}{l}\text { Time to peak, } \\
\text { in hours }\end{array}$ \\
\hline 13 & $\begin{array}{l}2.7 \mathrm{~km} \text { downstream of confluence between } \\
\text { Río Toro Negro and Río Grande de Manatí }\end{array}$ & 24.7 & $\begin{array}{l}1,414.58 \\
(49,963)\end{array}$ & $\begin{array}{c}51.18 \\
(167.93)\end{array}$ & 1 \\
\hline 11 & $0.6 \mathrm{~km}$ upstream from $\mathrm{PR}-145$ bridge & 28.2 & $\begin{array}{l}1,109.09 \\
(39,173)\end{array}$ & $\begin{array}{c}40.88 \\
(134.14)\end{array}$ & 1.25 \\
\hline 9 & PR-6685 bridge & 32.7 & $\begin{array}{c}999.61 \\
(35,306)\end{array}$ & $\begin{array}{c}26.45 \\
(86.78)\end{array}$ & 1.5 \\
\hline 7 & $1.7 \mathrm{~km}$ upstream from PR-642 bridge & 36.8 & $\begin{array}{c}842.94 \\
(29,772)\end{array}$ & $\begin{array}{c}18.36 \\
(60.25)\end{array}$ & 2 \\
\hline 5 & $1.8 \mathrm{~km}$ south of Manatí town & 41.5 & $\begin{array}{c}624.79 \\
(22,067)\end{array}$ & $\begin{array}{c}13.76 \\
(45.16)\end{array}$ & 2.5 \\
\hline 3 & PR-2 bridge & 48.6 & $\begin{array}{c}471.01 \\
(16,636)\end{array}$ & $\begin{array}{c}6.57 \\
(21.57)\end{array}$ & 4 \\
\hline 1.4 & Near town of Barceloneta at PR-22 bridge & 53.4 & $\begin{array}{c}387.72 \\
(13,694)\end{array}$ & $\begin{array}{c}4.33 \\
(14.20)\end{array}$ & 5 \\
\hline
\end{tabular}

Table 12. Breach parameters used in the sensitivity analysis considering adjustments in the final bottom-width for the dam failure analysis of Lago de Matrullas Dam, Orocovis, Puerto Rico.

[HEC-RAS, Hydrologic Engineering Center-River Analysis System; hr, hour; PMP, probable maximum precipitation; Ov, overtopped; PP, piping; ws, water surface; N/A, not applicable]

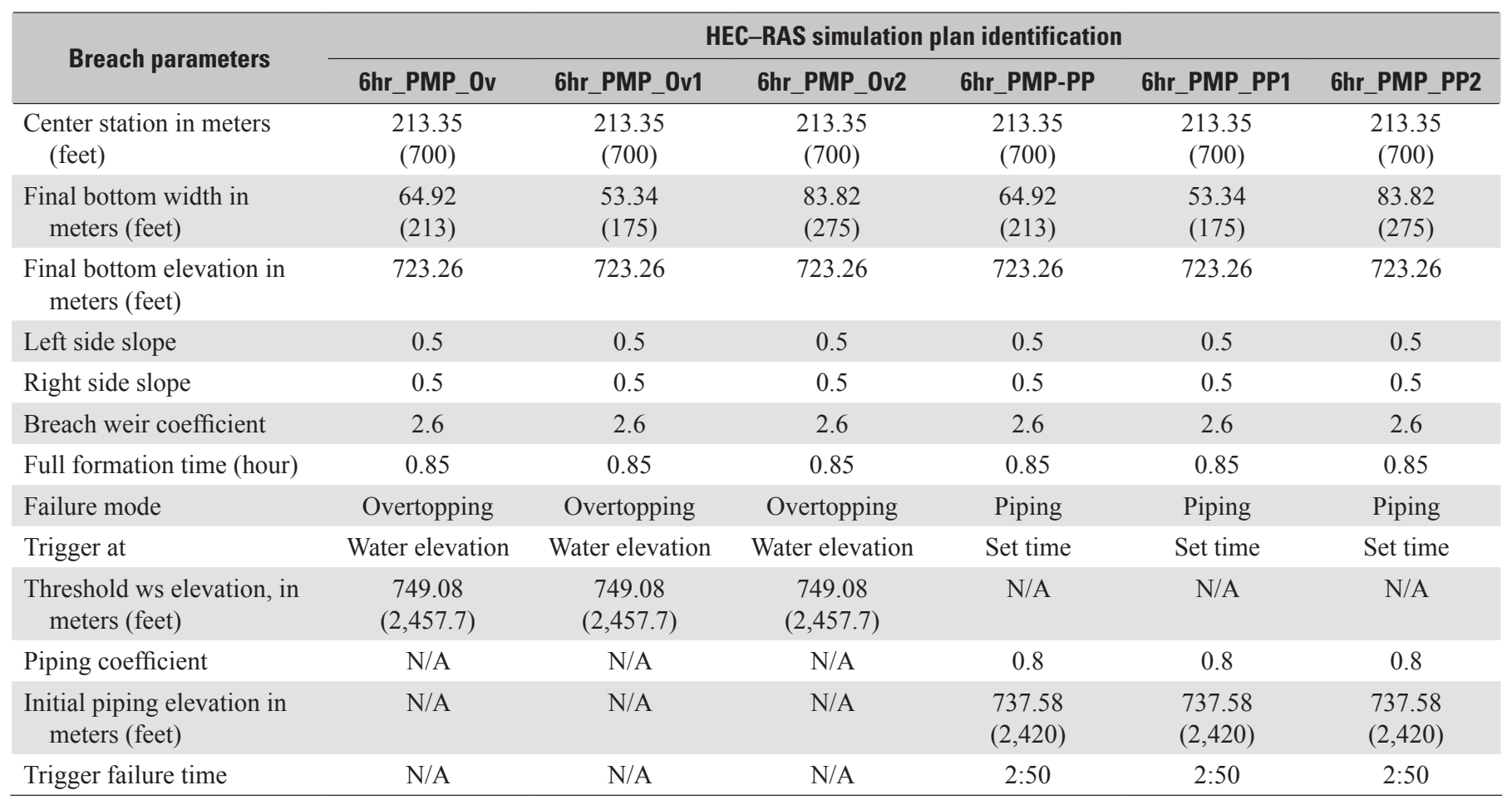


Table 13. Breach parameters used in the sensitivity analysis considering adjustments in the breach formation time for the dam failure analysis of Lago de Matrullas Dam, Orocovis, Puerto Rico.

[HEC-RAS, Hydrologic Engineering Center-River Analysis System; hr, hour; PMP, probable maximum precipitation; Ov, overtopped; PP, piping; ws, water surface; N/A, not applicable]

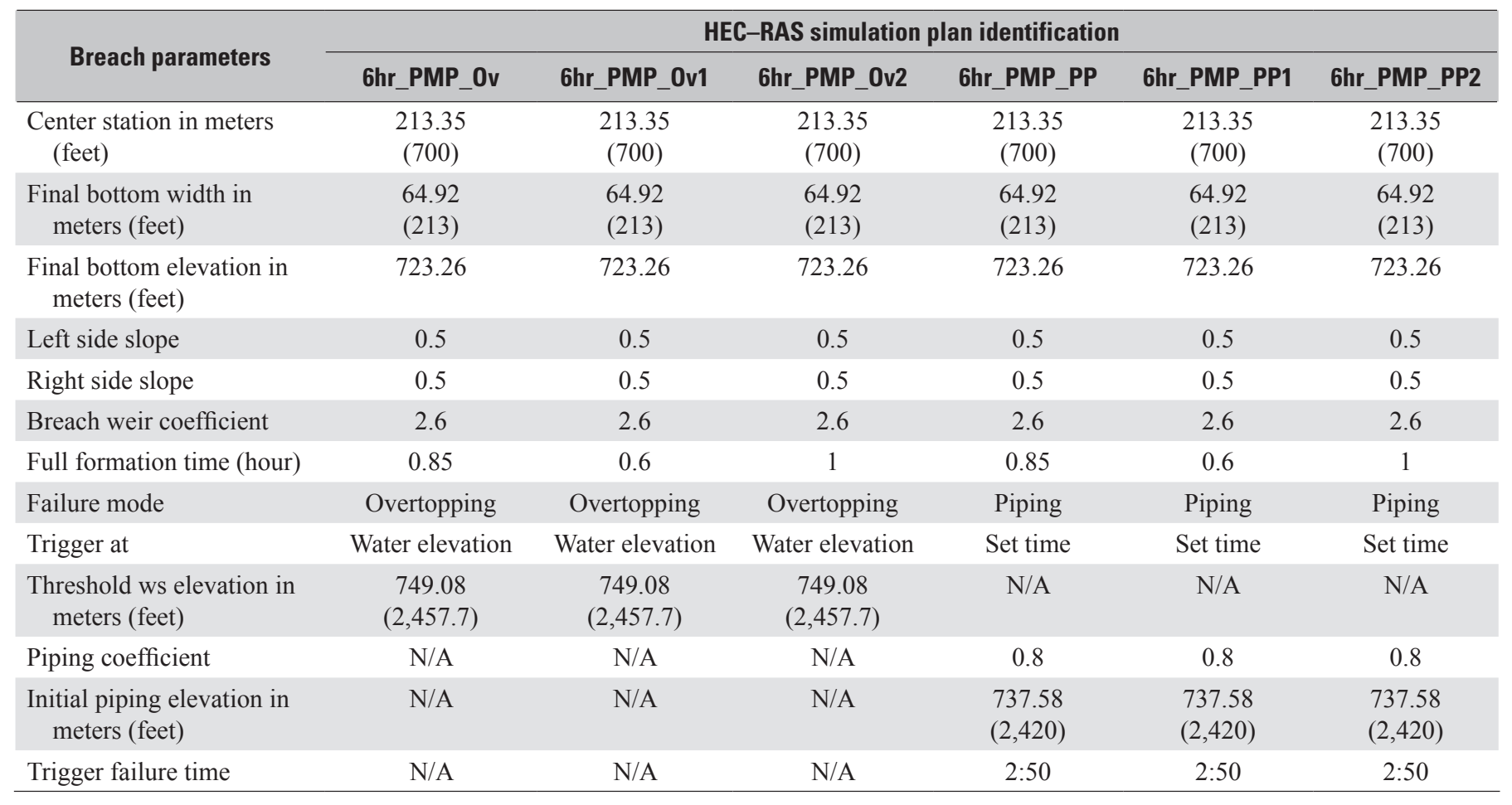

Table 14. Peak discharge at Lago de Matrullas Dam, Orocovis Puerto Rico for the sensitivity analysis of breach parameters.

[HEC-RAS, Hydrologic Engineering Center-River Analysis System; hr, hour; PMP, probable maximum precipitation; Ov, overtopped; PP, piping; N/A, not applicable]

\begin{tabular}{|c|c|c|c|}
\hline Description & $\begin{array}{c}\text { HEC }- \text { RAS plan } \\
\text { simulation identification }\end{array}$ & $\begin{array}{l}\text { Peak discharge at dam, } \\
\text { in cubic meters per second } \\
\text { (in cubic feet per second) }\end{array}$ & $\begin{array}{l}\text { Percent } \\
\text { difference }\end{array}$ \\
\hline Simulation base (overtopping failure) & 6hr_PMP_Ov & $3,149.33(111,234)$ & $\mathrm{N} / \mathrm{A}$ \\
\hline Final bottom width decreased & 6hr_PMP_Ov1 & $3,139.77(110,896)$ & -0.3 \\
\hline Breach formation time decreased & 6hr_PMP_Ov3 & $4,264.04(150,605)$ & 35.4 \\
\hline Breach formation time increased & 6hr_PMP_Ov4 & $2,792.17(98,619)$ & -11.3 \\
\hline Simulation base (piping failure) & 6hr_PMP_PP & $3,200.6(113,045)$ & N/A \\
\hline Breach formation time decreased & 6hr_PMP_PP3 & $3,701.27(130,728)$ & 15.6 \\
\hline Breach formation time increased & 6hr_PMP_PP4 & $2,698.62(95,315)$ & -15.7 \\
\hline
\end{tabular}




\section{Inundation Maps}

Inundation maps delineating the areas that would be flooded as a result of the hypothetical dam failures were prepared for each simulated flood condition (plates 1-4). The flood boundaries are based on the maximum water-surface elevations resulting from the simulated dam breaches. Inundation maps were delineated for the Río Grande de Manatí lower reach and, because the inundation boundaries are approximate, the results may not include areas where shallow flooding would occur. The delineation of the flood boundaries near the town of Barceloneta considered the effects of the levee recently constructed in the flood plain of the Río Grande de Manatí to provide flood protection to the low-lying populated areas of the town.

In addition to showing the flood boundaries, the inundation maps present information at critical locations, such as the distance from the dam, flood peak or maximum water-surface elevation, and elapsed period between the time of dam failure and peak water level (time to peak). The dam failure results at selected locations along the lower reach of the Río Grande de Manatí for the 6- and 24-hour PMP events are shown in plates 1 and 2, respectively. The 24-hour, 100-year flood dam failure results are shown in plate 3 , and results for a dam failure under sunny day conditions are shown in plate 4 .

Model results indicate that a failure of the Lago de Matrullas Dam under any of the simulated flood conditions would result in severe flooding of downstream populated urban and rural areas and farmlands. The levee built near Barceloneta would be overtopped for the hypothetical 6- and 24-hour PMP events but not overtopped for the 100-year, 24-hour rainfall event and for sunny day conditions. The areas most affected include, among others, the low-lying areas of the towns of Ciales, Manatí, and Barceloneta.

\section{Uncertainties in the Flood Inundations Maps}

Several uncertainties are inherent in the preparation of flood inundation maps used to represent the flooding caused by dam failure. The sources of uncertainty include the available topographic and hydraulic data, as well as the modeling assumptions used in the analysis. These uncertainties and assumptions can lead to results that differ from those that would occur during a real event. In addition, not all physical processes are considered in the model, such as sediment transport and scour that may occur during dam failure and the resultant flood-wave propagation; both processes may cause changes in the channel geometry. Another assumption made as part of the analysis was that hydraulic structures, such as bridges, that are exposed to potential hazards during flood events would not collapse during the simulation. Another source of uncertainty is in the breach development model used; even though it is based on specific dam characteristics and empirical relations, the model can only simulate hypothetical dam failure scenarios. As indicated by the sensitivity analysis results, peak discharge is strongly affected by variations in the breach model parameters, specifically, final breach width and breach formation time. Thus, the peak discharge and flood-wave travel time represented in the inundation map can vary greatly depending on the actual nature of the dam breach.

\section{Summary and Conclusions}

Hydrologic and hydraulic analyses were conducted to assess the potential hazard to human life and property downstream from the Lago de Matrullas Dam associated with hypothetical failure of the dam under 6- and 24-hour probable maximum precipitation (PMP) events, a 24-hour, 100-year-recurrence rainfall event, and non-flood conditions ("sunny day" failure). These analyses were conducted in order to prepare inundation maps that delineate the areas that would be flooded as a result of dam failure. The dam failure analysis was conducted in cooperation with the Puerto Rico Electric Power Authority to enable the agency to prepare an Emergency Action Plan for the Lago de Matrullas Dam.

The hydrologic analyses consisted of defining runoff hydrographs and peak discharges for the Lago de Matrullas drainage basin and other subbasins within the Río Grande de Manatí hydrographic basin for the 6- and 24-hour PMP events and for the 24-hour, 100-year rainfall event. The U.S. Army Corps of Engineers Hydrologic Engineering Center's Hydrologic Modeling System (HEC-HMS) was used to determine these hydrographs and peak discharges. The peak inflow discharges at the Lago de Matrullas Dam for the 6- and 24-hour PMP storms were estimated to be 1,104 and 1,032 cubic meters per second $\left(\mathrm{m}^{3} / \mathrm{s}\right)$, respectively. The 24-hour, 100-year rainfall event produced a peak inflow discharge of about $418 \mathrm{~m}^{3} / \mathrm{s}$.

Results from the hydrologic analysis under non-failure conditions indicate that the 6- and 24-hour PMP floods would overtop the Lago de Matrullas Dam. Model results also indicate that the flood caused by a 100-year recurrence, 24-hour rainfall event would not overtop the dam. Lago de Matrullas has little effect on reducing these flood flows because of its reduced storage capacity, and consequently, substantial floods were simulated downstream from the Lago de Matrullas Dam under non-failure conditions.

Hypothetical failure of the Lago de Matrullas Dam was simulated under four conditions: 6- and 24-hour PMP events, a 100-year-recurrence, 24-hour rainfall event, and a sunny day. The U.S. Army Corps of Engineers Hydrologic Engineering Center's River Analysis System (HEC-RAS) was used to determine flood level, flood peak, and time to peak since dam failure at specified locations downstream from the dam for each simulated breach condition. The dam failure analysis was performed using the unsteady flow module available in HEC-RAS. 
The dam failure for the 6- and 24-hour PMP events was set to begin when the water-surface elevation exceeded the top of the dam by 0.5 meter $(\mathrm{m})$, which indicates that watersurface elevation in the reservoir at the beginning of dam failure was $749.08 \mathrm{~m}$. Failure criteria applied under hydrologic conditions for the 6- and 24-hour PMP events was overtopping. At the toe of Lago de Matrullas Dam, the computed peak discharges produced by the dam failure were $3,149.33 \mathrm{~m}^{3} / \mathrm{s}$ for the 6-hour PMP event and 3,604.7 $\mathrm{m}^{3} / \mathrm{s}$ for the 24-hour PMP event. The flood wave was downstream-routed along the lower reaches of Río Matrullas, Río Toro Negro, and Río Grande de Manatí. Along Río Grande de Manatí about 0.6 kilometer $(\mathrm{km})$ upstream from the PR-145 bridge, the peak discharges were $12,995.44 \mathrm{~m}^{3} / \mathrm{s}$ for the 6-hour PMP event and $14,800.87 .16 \mathrm{~m}^{3} / \mathrm{s}$ for the 24-hour PMP event. At the PR-22 bridge near the town of Barceloneta, the peak discharge was $12,781.07 \mathrm{~m}^{3} / \mathrm{s}$ for the 6-hour PMP event and 14,549.13 $\mathrm{m}^{3} / \mathrm{s}$ for the 24-hour PMP event. The flood-wave arrival time near the town of Barceloneta was approximately 2.75 and 2.5 hours for the 6- and 24-hour PMP events, respectively.

The dam failure for the 24-hour, 100-year rainfall event was initiated when the peak discharge arrived at the dam and the selected failure criteria were by piping failure. The reservoir pool elevation when breaching began was $745.38 \mathrm{~m}$. At the toe of the Lago de Matrullas Dam, the computed peak discharge produced by the dam failure was $2,103.12 \mathrm{~m}^{3} / \mathrm{s}$. The peak flow along the Río Grande de Manatí lower reach was $5,545.48 \mathrm{~m}^{3} / \mathrm{s}$ at $0.6 \mathrm{~km}$ upstream of the PR-145 bridge and $4,834.68 \mathrm{~m}^{3} / \mathrm{s}$ at the PR-22 bridge.

Failure of the Lago de Matrullas Dam under sunny day conditions was initiated at a reservoir pool elevation of $743.5 \mathrm{~m}$. The peak discharge directly downstream from the Lago de Matrullas Dam was $1,695.91 \mathrm{~m}^{3} / \mathrm{s}$. Along the Rio Grande de Manatí lower reach, the peak discharge was $1,109.09 \mathrm{~m}^{3} / \mathrm{s}$ at $0.6 \mathrm{~km}$ upstream of the PR-145 bridge. The flood wave at the PR-22 bridge, near the town of Barceloneta, had a peak discharge of $387.72 \mathrm{~m}^{3} / \mathrm{s}$ and the flood-wave arrival time was approximately 5 hours.

Model results indicate that a failure of the Lago de Matrullas Dam during any of the simulated flow conditions would result in flooding of downstream urban and rural populated areas and farmlands. Among the areas most affected were the low-lying areas in the towns of Ciales, Manatí, and Barceloneta. The results showed that several bridges located along the Río Grande de Manatí lower reach would experience overtopping during the simulated failure for the hydrologic conditions of 6- and 24-hour PMP, as well as the 24-hour, 100 -year rainfall event. Dam failure simulation under sunnyday conditions showed no bridge overtopping along the lower reach of the Río Grande de Manatí.

\section{References Cited}

Barnes, H.H., Jr., 1967, Roughness characteristics of natural channels: U.S. Geological Survey Water-Supply Paper $1849,213 \mathrm{p}$.

Boccheciamp, R.A., 1978, Soil survey of the San Juan area of Puerto Rico: U.S. Department of Agriculture, Soil Conservation Service, $21 \mathrm{p}$.

Carter, R.W., and Godfrey, R.G., 1960, Storage and flood routing-Manual of hydrology: Part 3. Flood flow techniques: U.S. Geological Survey Water-Supply Paper 1543-B.

Chen, Y.H., 1973, Mathematical modeling of water and sediment routing in natural channels: Ft. Collins, Colorado State University, Department of Civil Engineering, Ph.D. dissertation.

Federal Emergency Management Agency, 2013, Federal guidelines for inundation mapping of flood risks associated with dam incident and failures (1st ed): Federal Emergency Management Agency Report FEMA P-946.

Figueroa-Alamo, Carlos., Aquino, Z., Guzmán-Ríos, S., and Sánchez, A.,2004, Water resources data Puerto Rico and the U.S. Virgin Islands - Water Year 2004: U.S. Geological Survey Water-Data Report PR-04-1.

Gupta, R., 2001, Measurement of Surface Water Flow, chap. 6 of Hydrology and hydraulics systems: Prospect Heights, Ill., Waveland Press, Inc.

Liggett, J.A., and Cunge, J.A., 1975, Numerical methods of solutions of the unsteady flow equations, in Mahmood, K., and Yevjevich, V., eds., Unsteady flow in open channels, v. 1, chap. 4: Ft. Collins, Colo., Water Resources Publications.

Mays, L., 2005, Surface Runoff, chap. 8 of Water resources engineering: Phoenix, Ariz., John Wiley \& Sons.

McCuen, R., 2005, Precipitation, chap. 4 of Hydrologic analysis and design: Upper Saddle River, N.J., Pearson Prentice Hall.

National Oceanic and Atmospheric Administration, 2006, Precipitation-frequency atlas of the United States: Silver Spring, Md., National Oceanic and Atmospheric Administration Atlas 14, v. 3, version 4.0.

National Oceanic and Atmospheric Administration, 2011, Climate Normals and All Time Records for Puerto Rico and U.S. Virgin Islands: Normals 1981-2010, accessed December 17, 2014: http://www.srh.noaa.gov/sju/?n=climo01. 
Natural Resources Conservation Service, 2003, National Land Cover Data Base - Commonwealth of Puerto Rico: Sioux Falls, S.D., accessed December 18, 2014: http://www.mrlc.gov/nlcd01_data.php.

Natural Resources Conservation Service, 2013, Soil Survey Geographic (SSURGO) Data Base: Fort Worth, Tex., accessed December 29, 2014: http://websoilsurvey.nrcs.usda.gov.

Puerto Rico Electric Power Authority, 1980a, Matrullas Dam, Orocovis, Puerto Rico, Phase 1 Inspection Report: National Dam Safety Program unpublished report. [Report available for inspection at the USGS office in San Juan, Puerto Rico]

Puerto Rico Electric Power Authority, 1980b, Guineo Dam, Ciales-Orocovis, Puerto Rico, Phase 1 Inspection Report: National Dam Safety Program unpublished report, section 1, p. 1-4, 2 pls. [Report available for inspection at the USGS office in San Juan, Puerto Rico]

Soil Conservation Service, 1986, Urban hydrology for small watersheds: Springfield, Va., U.S. Department of Agriculture Technical Report 55.

Soler-López, 2003a, Sedimentation survey of Lago de Matrullas, Puerto Rico, December 2001: U.S. Geological Survey Water-Resources Investigations Report 03-4102, 24 p., 2 pls.

Soler-López, 2003b, Sedimentation survey of Lago El Guineo, Puerto Rico, October 2001: U.S. Geological Survey Scientific Investigations Report 03-4093, 21 p., 2 pls.
U.S. Army Corps of Engineers, 2000, HEC-HMS, Hydrologic modeling system technical reference manual, version 3.5, March 2000: Davis, Calif., U.S. Army Corps of Engineers Hydrologic Engineering Center.

U.S. Army Corps of Engineers, 2010a, HEC-HMS, Hydrologic modeling system user manual, version 3.5, August 2010: Davis, Calif., U.S. Army Corps of Engineers Hydrologic Engineering Center.

U.S. Army Corps of Engineers, 2010b, HEC-RAS river analysis system user manual, version 4.1.0, January 2010: Davis, Calif., U.S. Army Corps of Engineers Hydrologic Engineering Center.

U.S. Army Corps of Engineers, 2010c, Orthographic Imagery of Puerto Rico.

U.S. Bureau of Reclamation, 1998, Prediction of embankment dam breach parameters: Dam Safety Research Report DSO-98-004.

U.S. Department of Commerce, 1961, Generalized estimates of probable maximum precipitation and rainfall-frequency data for Puerto Rico and Virgin Islands: Washington D.C., U.S. Weather Bureau Technical Paper no. 42, 94 p.

U.S. Geological Survey, 2002, Watershed Boundary Dataset, accessed December 17, 2014: http://nhd.usgs.gov/wbd.html. 



\section{Appendix 1. HEC-HMS Output Hydrographs for the Dam Failure Analysis of Lago de Matrullas, Orocovis, Puerto Rico}




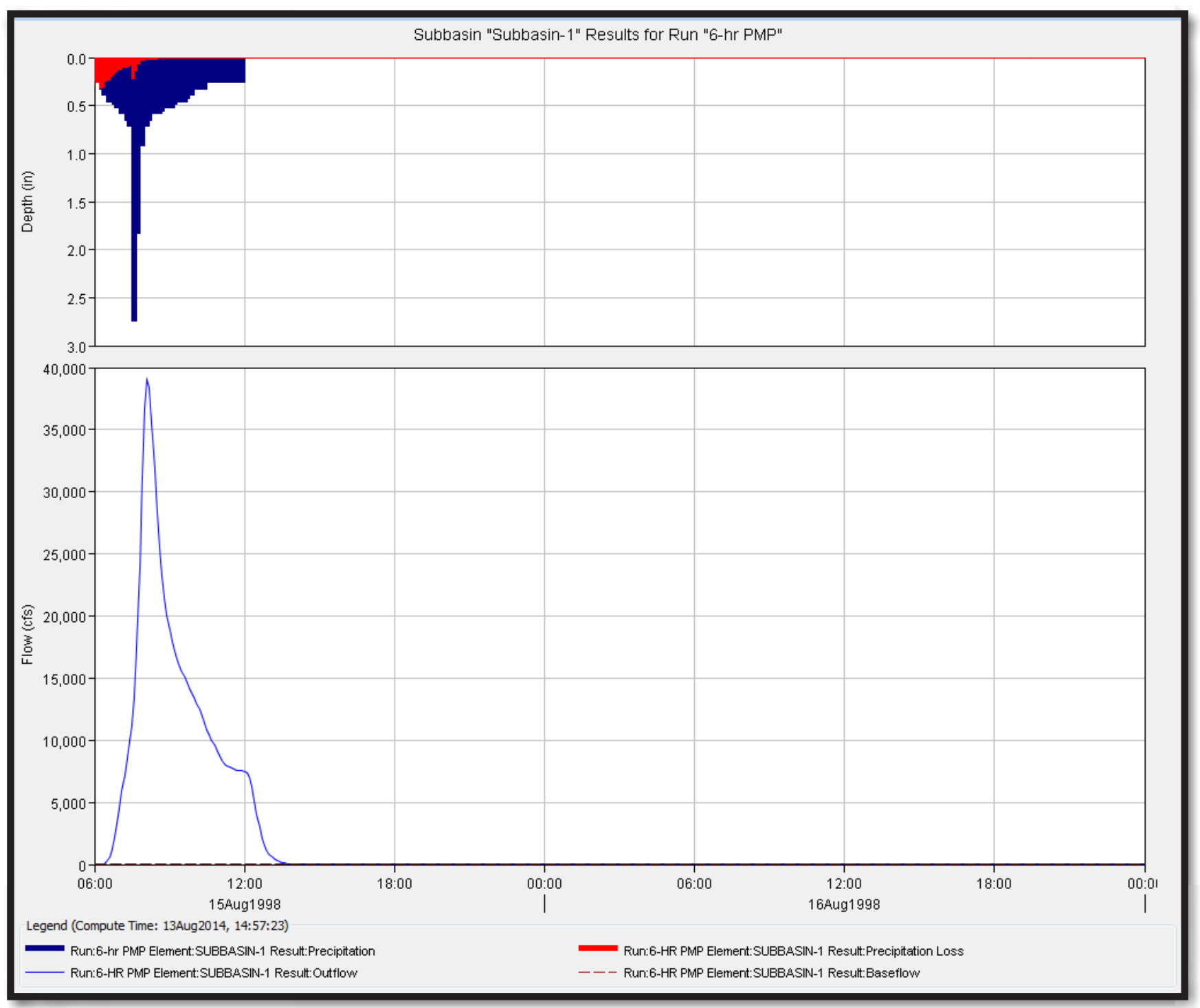

Figure 1-1. Output hydrograph screenshot for subbasin 1 from the 6-hour probable maximum precipitation (PMP) event. 


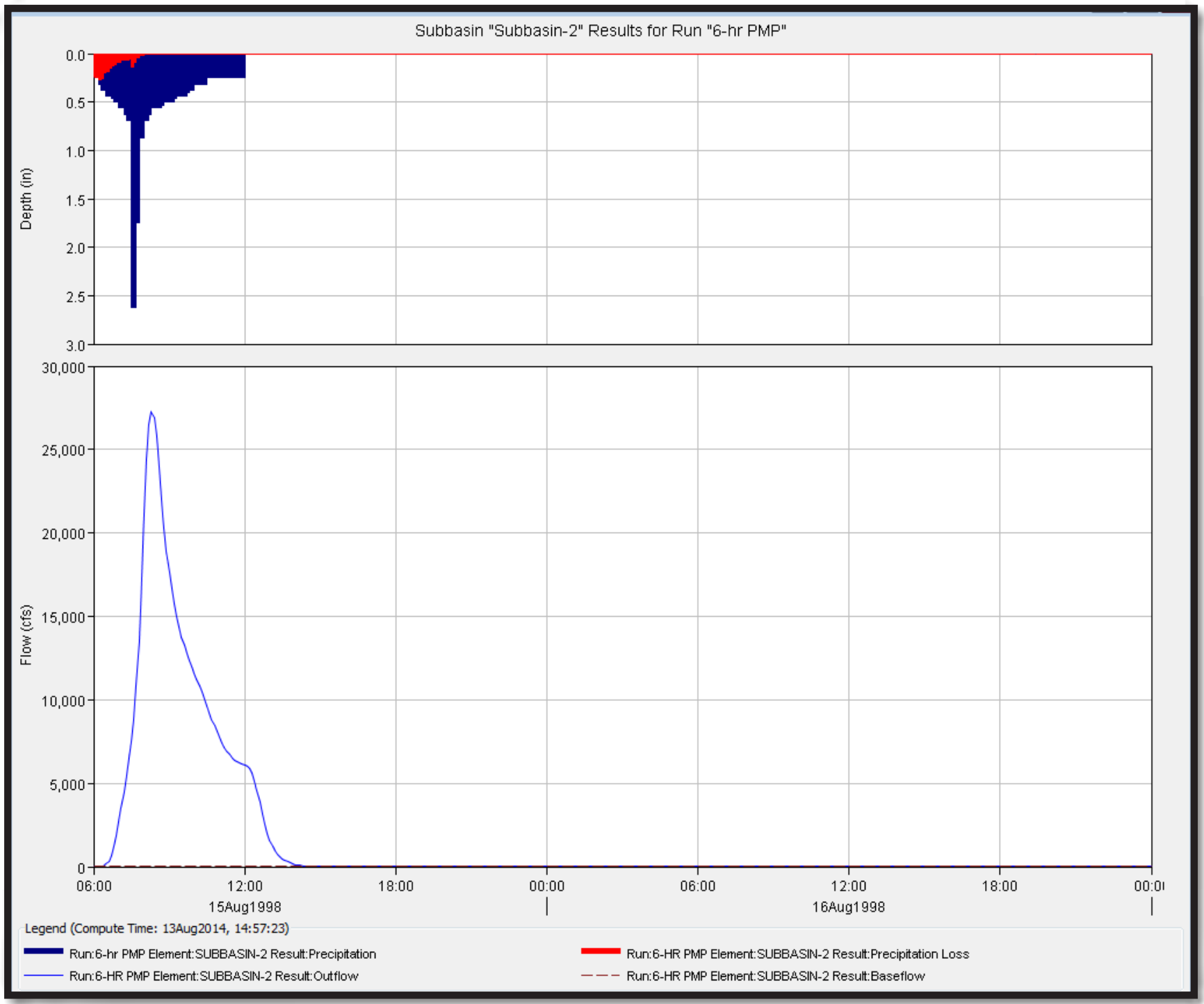

Figure 1-2. Output hydrograph screenshot for subbasin 2 from the 6-hour probable maximum precipitation (PMP) event. 


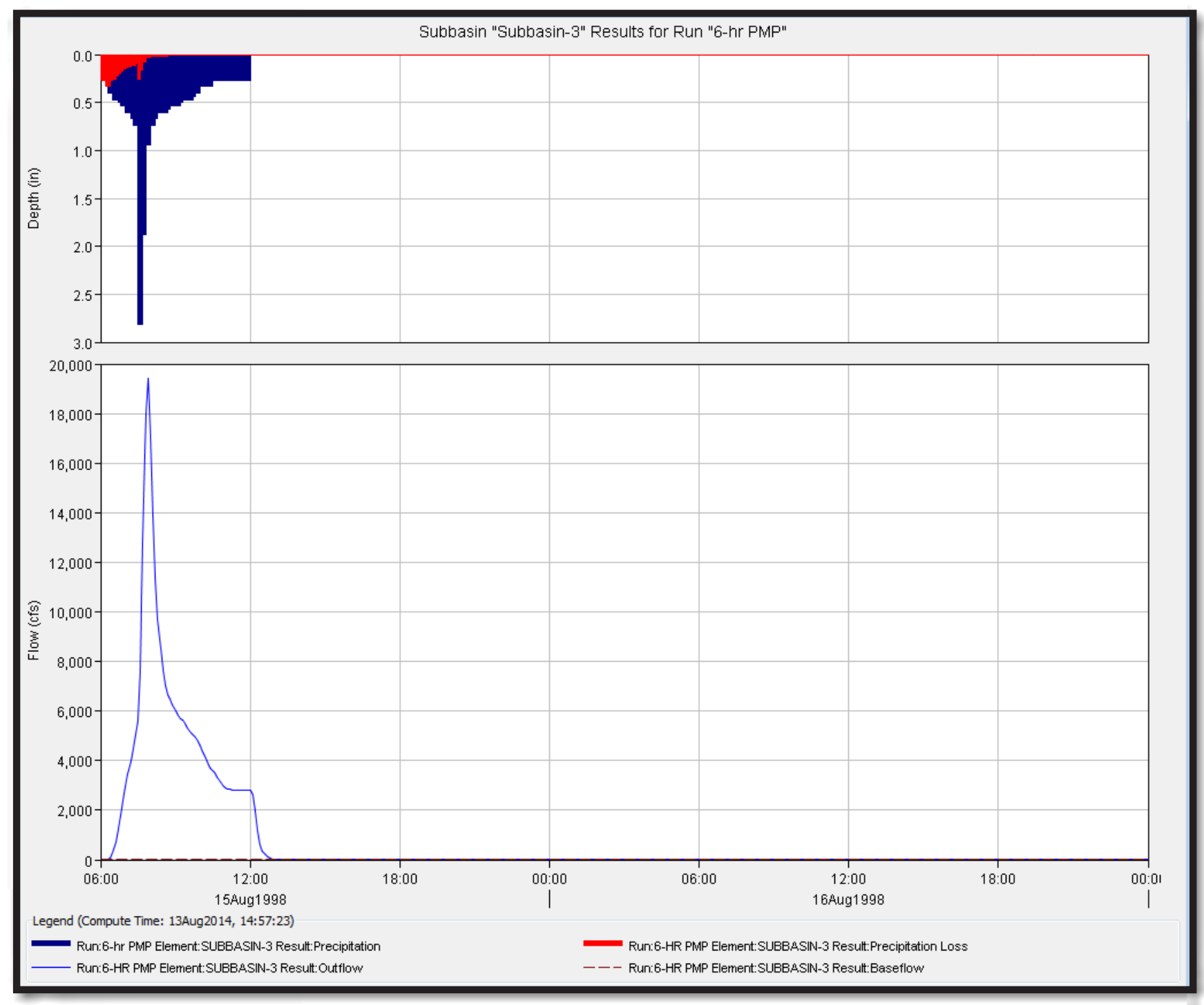

Figure 1-3. Output hydrograph screenshot for subbasin 3 from the 6-hour probable maximum precipitation (PMP) event. 


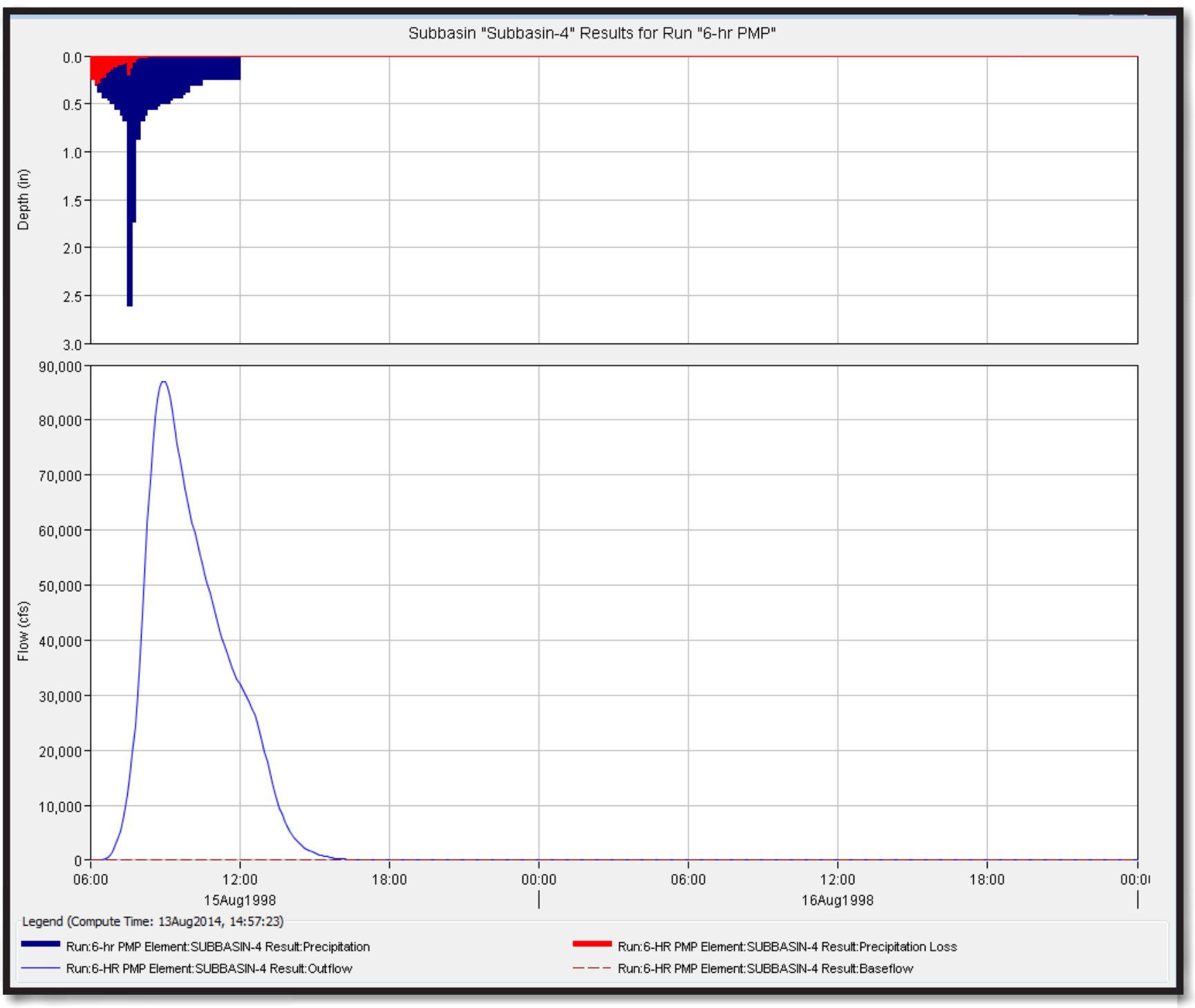

Figure 1-4. Output hydrograph screenshot for subbasin 4 from the 6-hour probable maximum precipitation (PMP) event. 


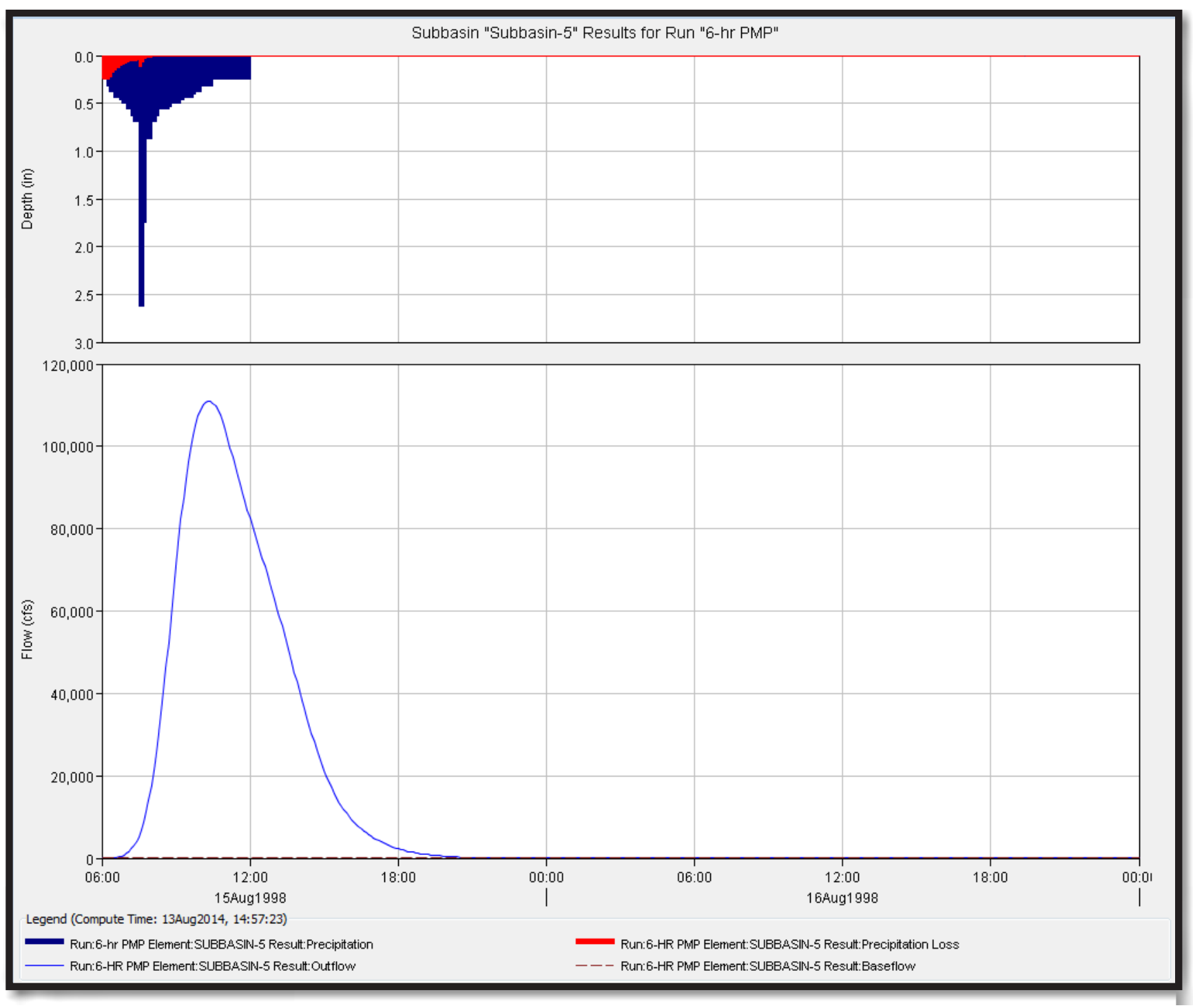

Figure 1-5. Output hydrograph screenshot for subbasin 5 from the 6-hour probable maximum precipitation (PMP) event. 

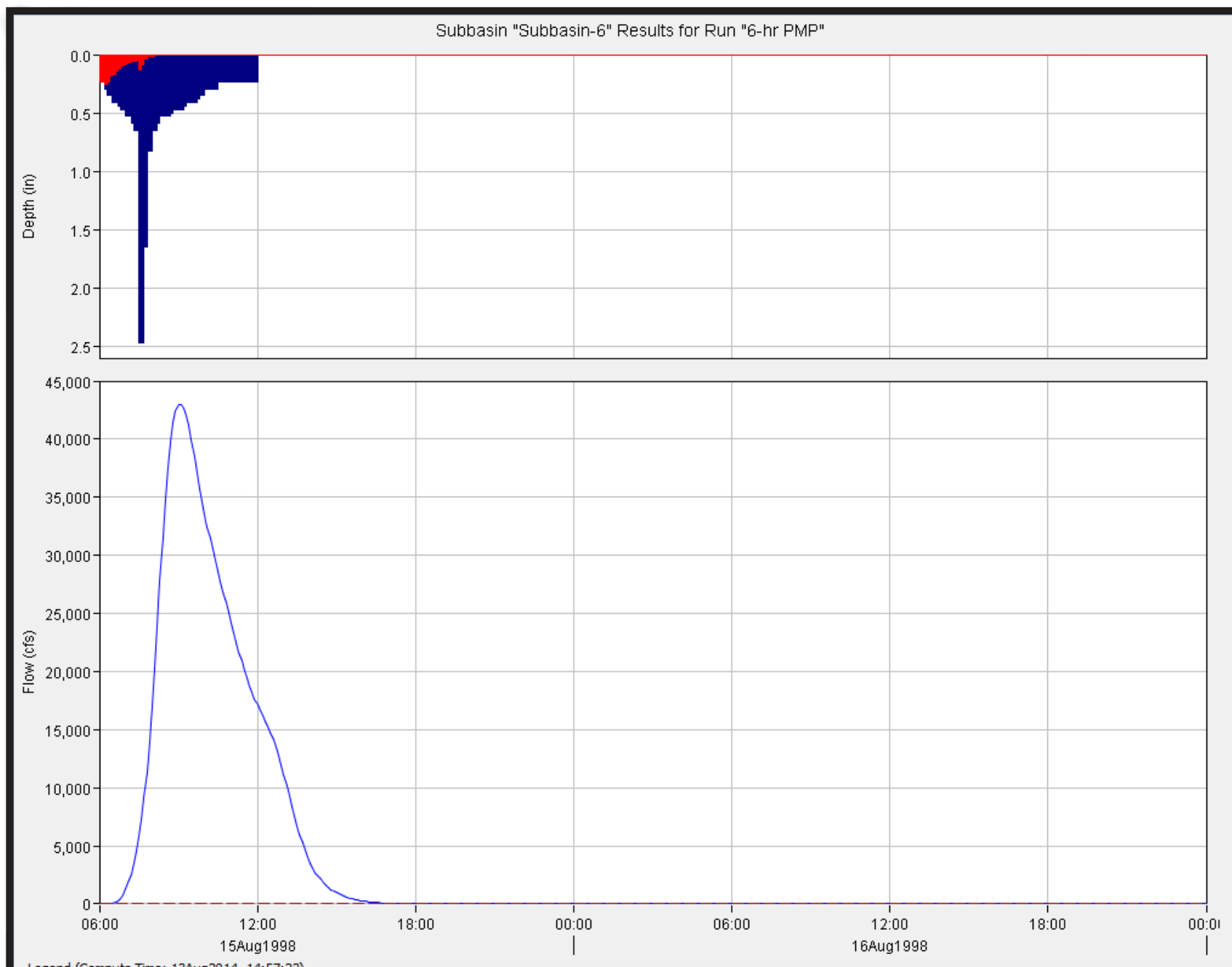

Legend (Compute Time: 13Aug2014, 14:57:23)

Figure 1-6. Output hydrograph screenshot for subbasin 6 from the 6-hour probable maximum precipitation (PMP) event. 


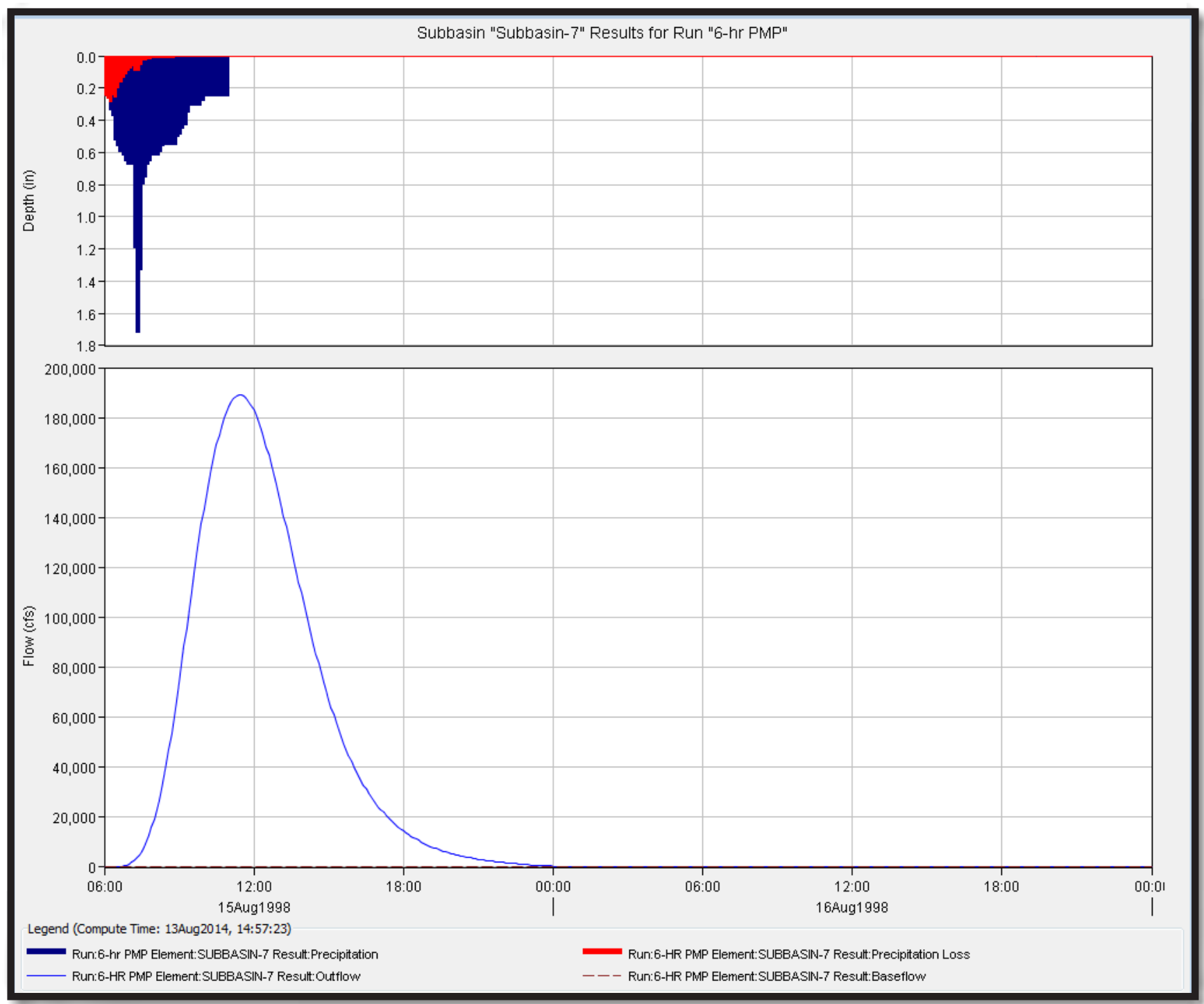

Figure 1-7. Output hydrograph screenshot for subbasin 7 from the 6-hour probable maximum precipitation (PMP) event. 
Appendix 1. HEC-HMS Output Hydrograph for the Dam Failure Analysis of Lago de Matrullas, Orocovis, Puerto Rico

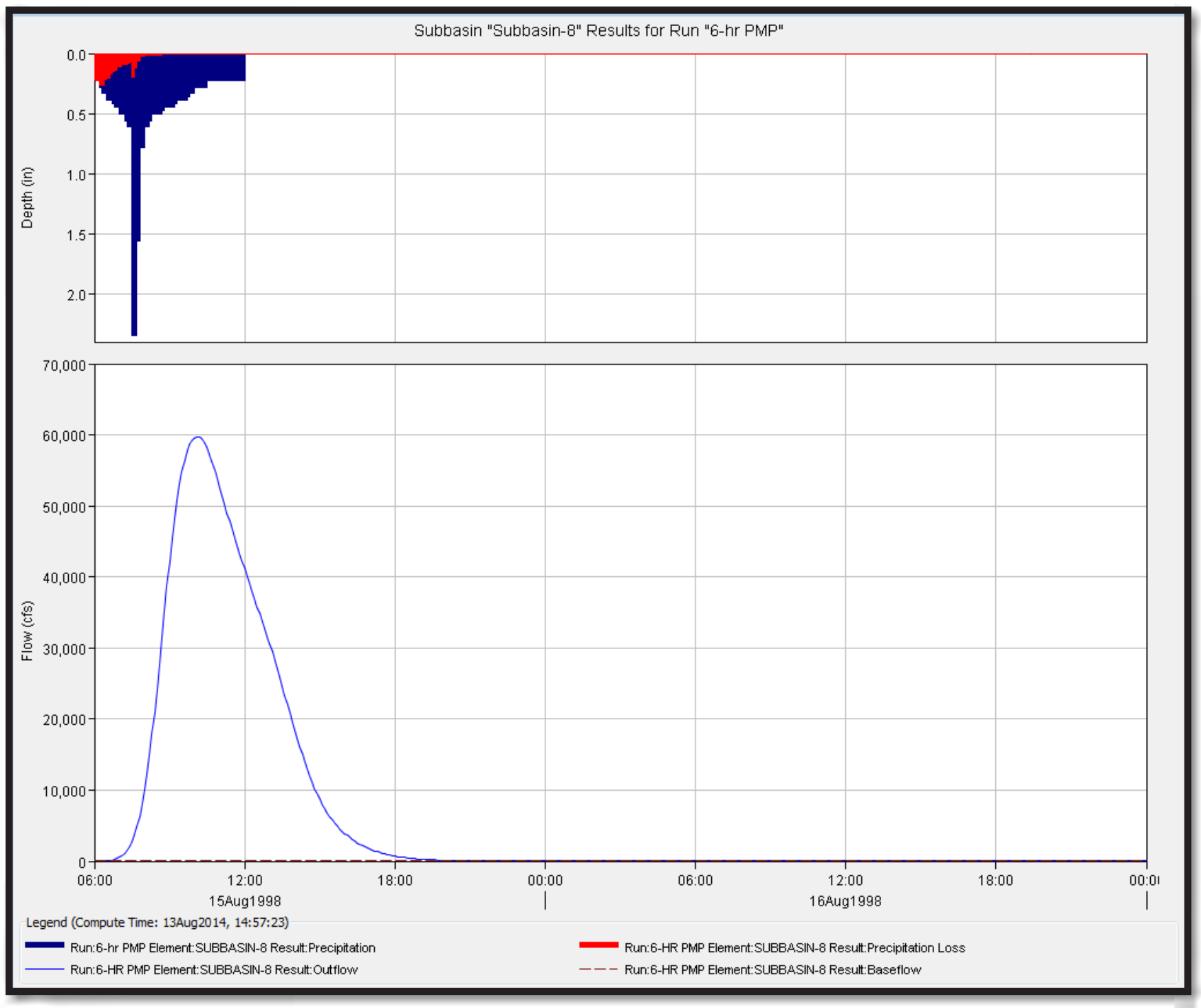

Figure 1-8. Output hydrograph screenshot for subbasin 8 from the 6-hour probable maximum precipitation (PMP) event. 

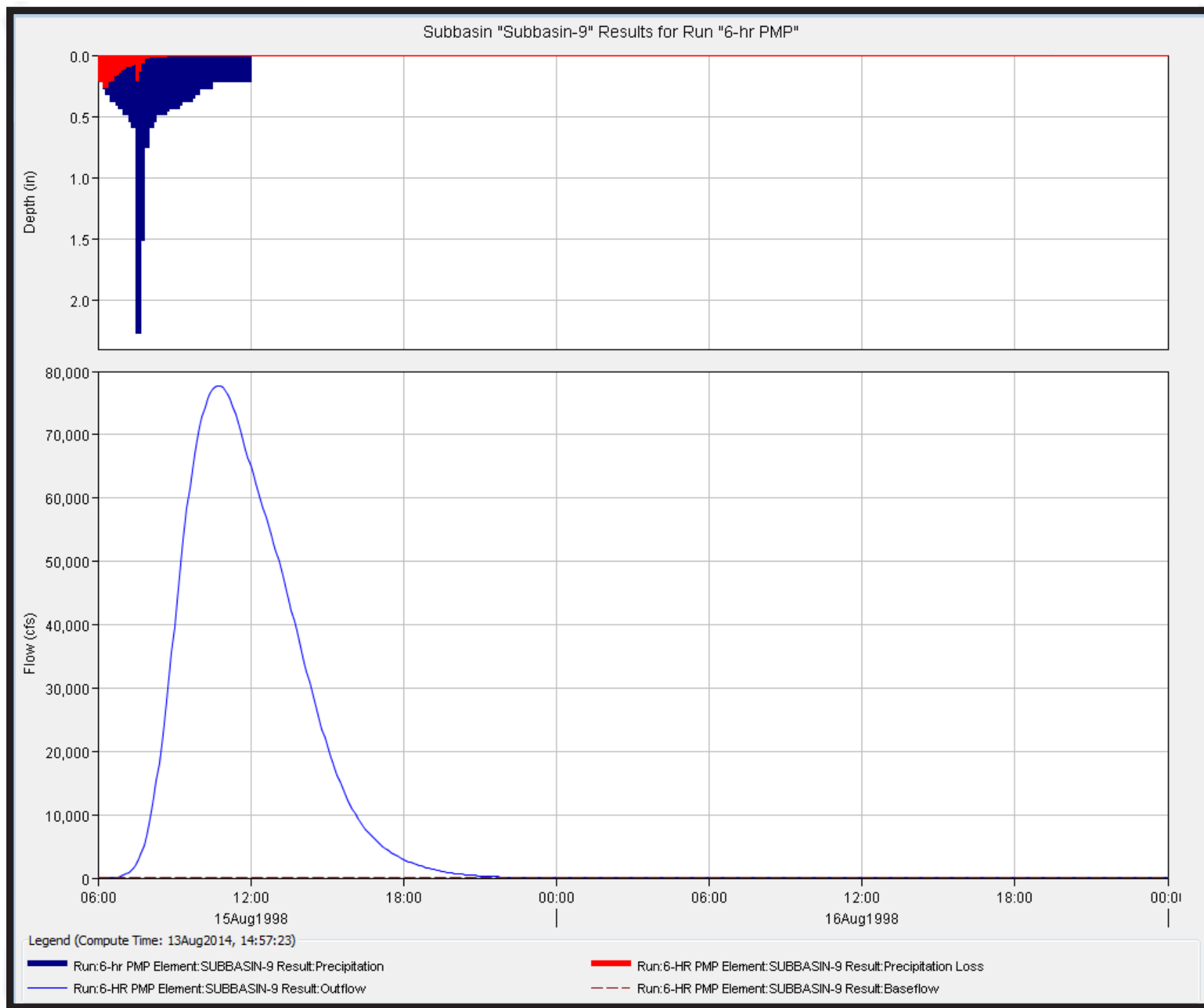

Figure 1-9. Output hydrograph screenshot for subbasin 9 from the 6-hour probable maximum precipitation (PMP) event. 


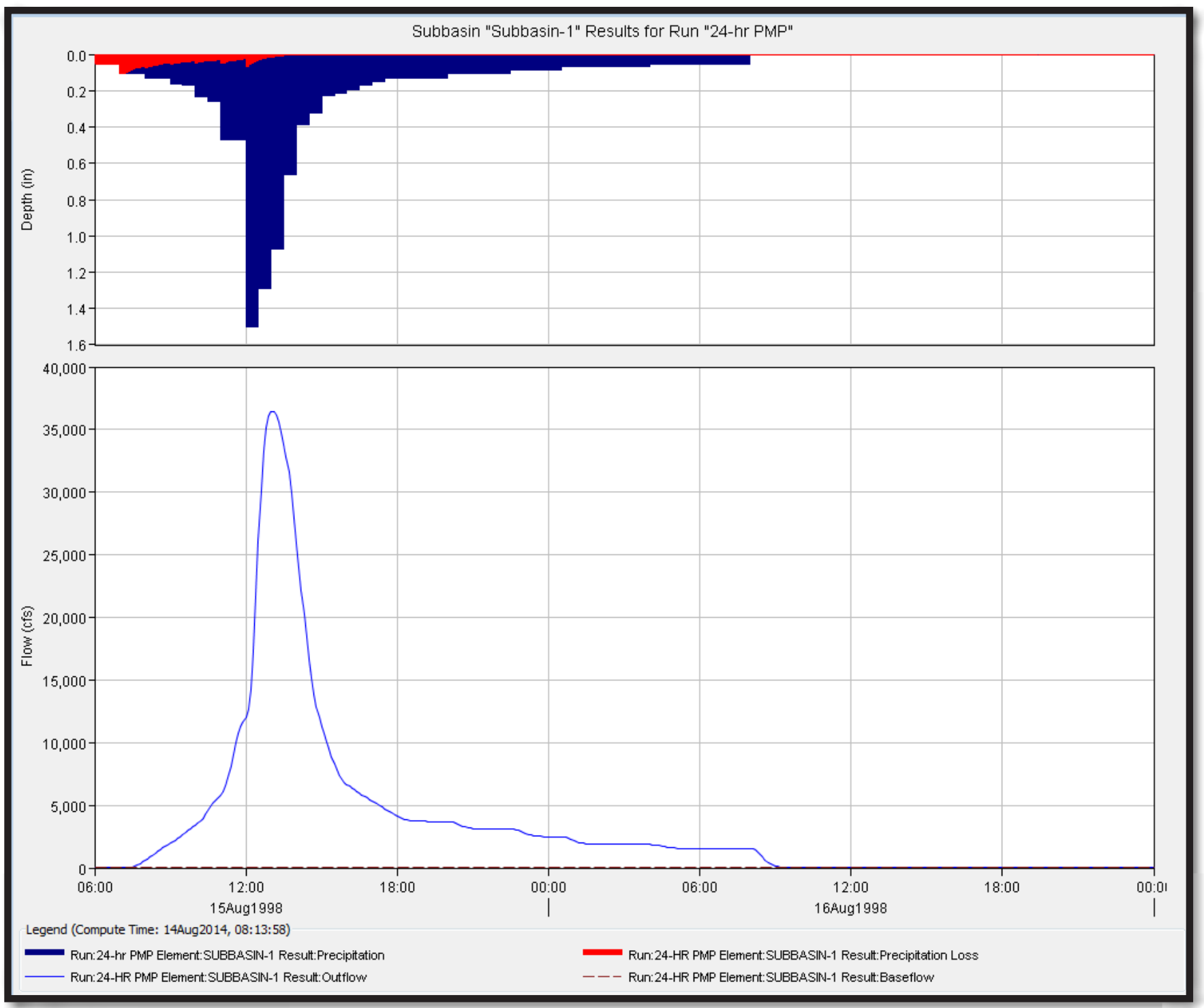

Figure 1-10. Output hydrograph screenshot for subbasin 1 from the 24-hour probable maximum precipitation (PMP) event. 


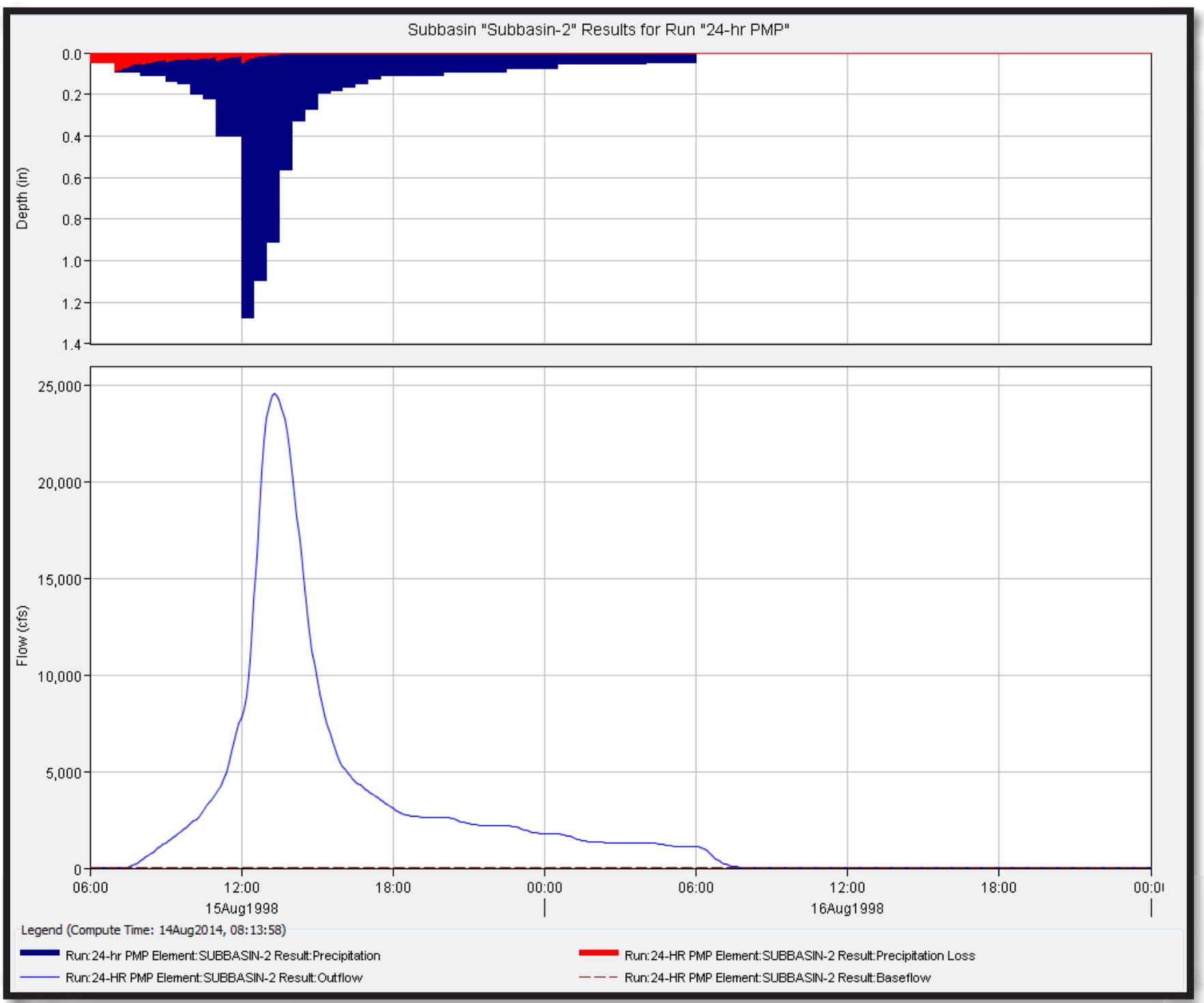

Figure 1-11. Output hydrograph screenshot for subbasin 2 from the 24-hour probable maximum precipitation (PMP) event. 
Appendix 1. HEC-HMS Output Hydrograph for the Dam Failure Analysis of Lago de Matrullas, Orocovis, Puerto Rico

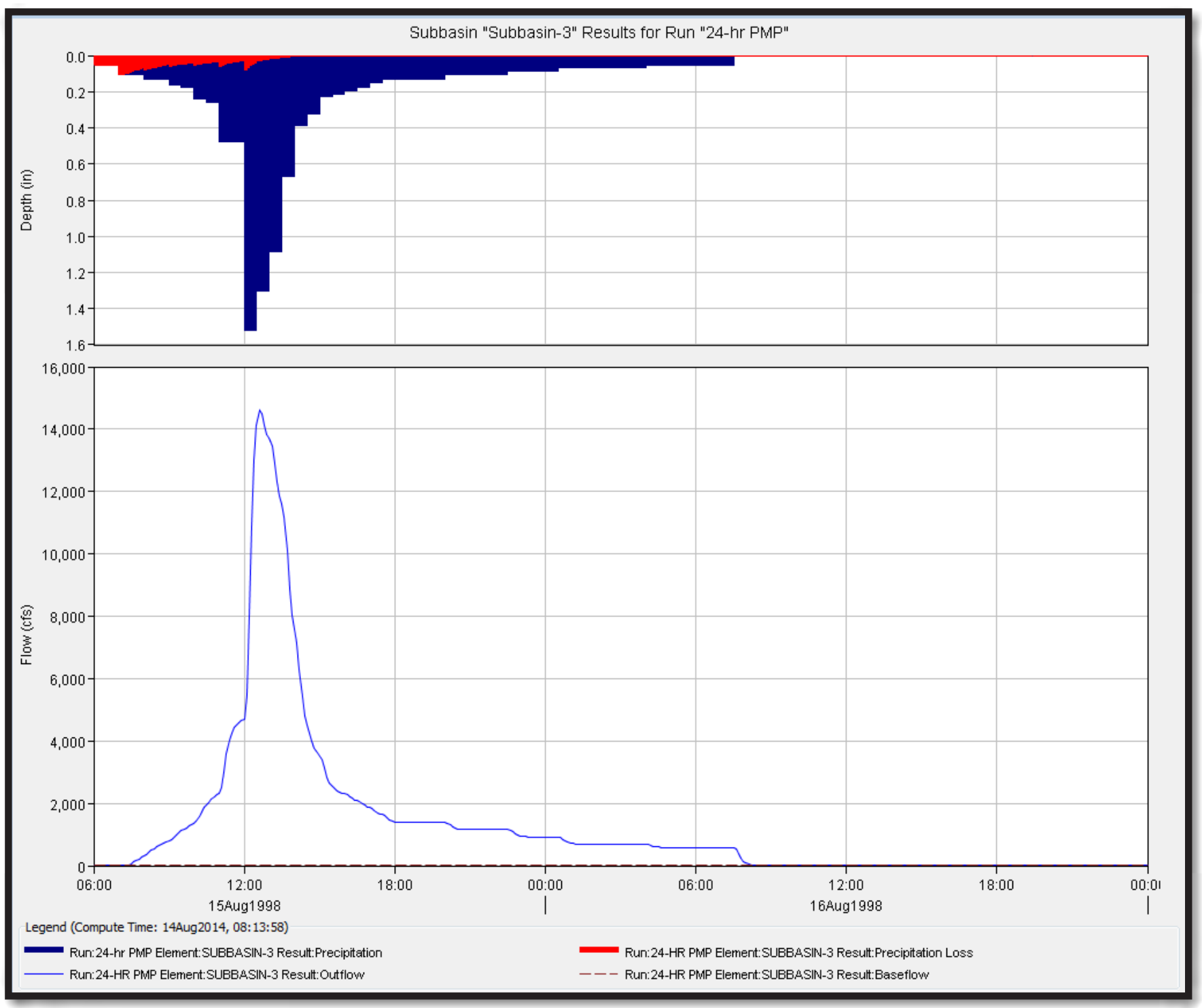

Figure 1-12. Output hydrograph screenshot for subbasin 2 from the 24-hour probable maximum precipitation (PMP) event. 


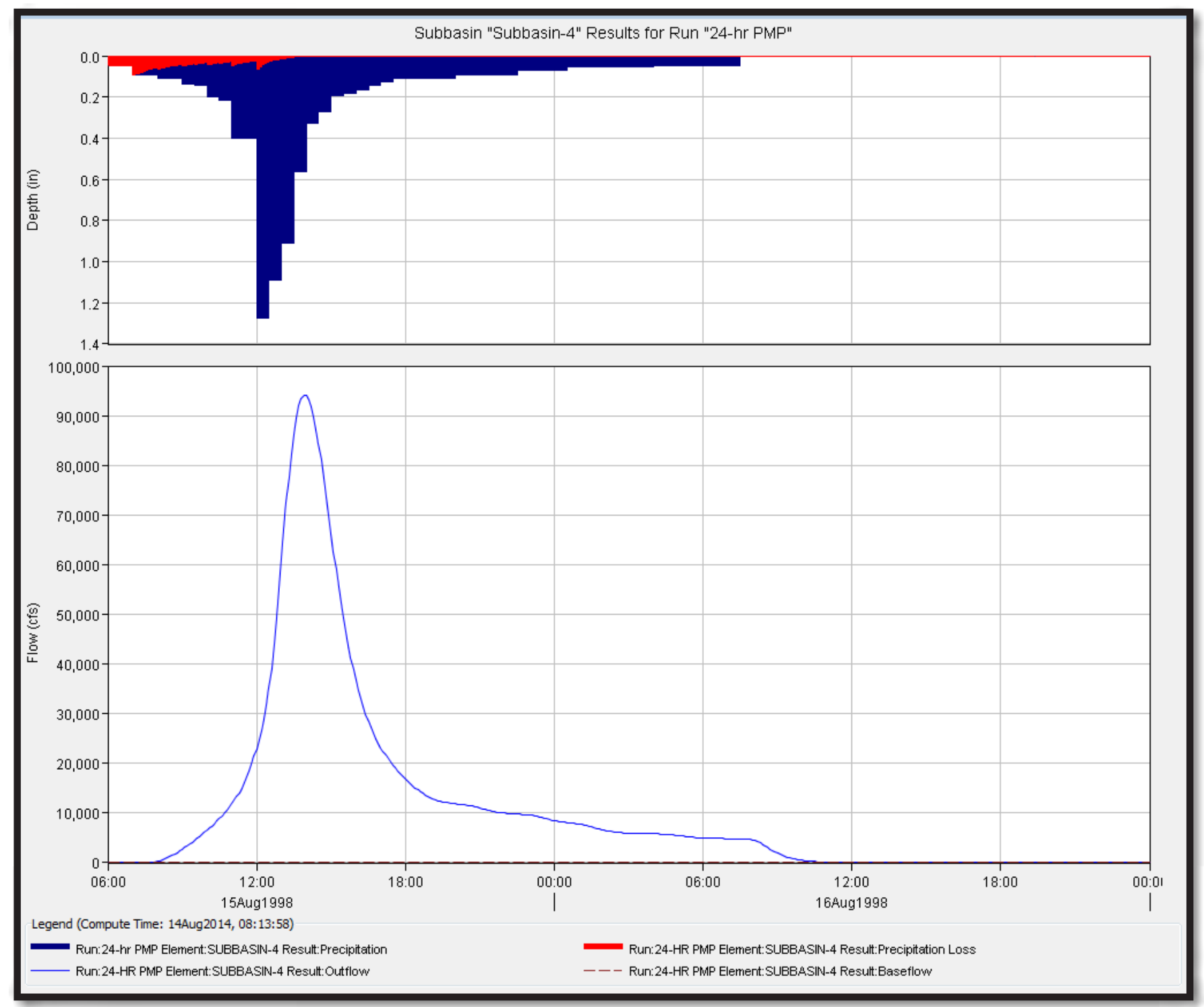

Figure 1-13. Output hydrograph screenshot for subbasin 4 from the 24-hour probable maximum precipitation (PMP) event. 


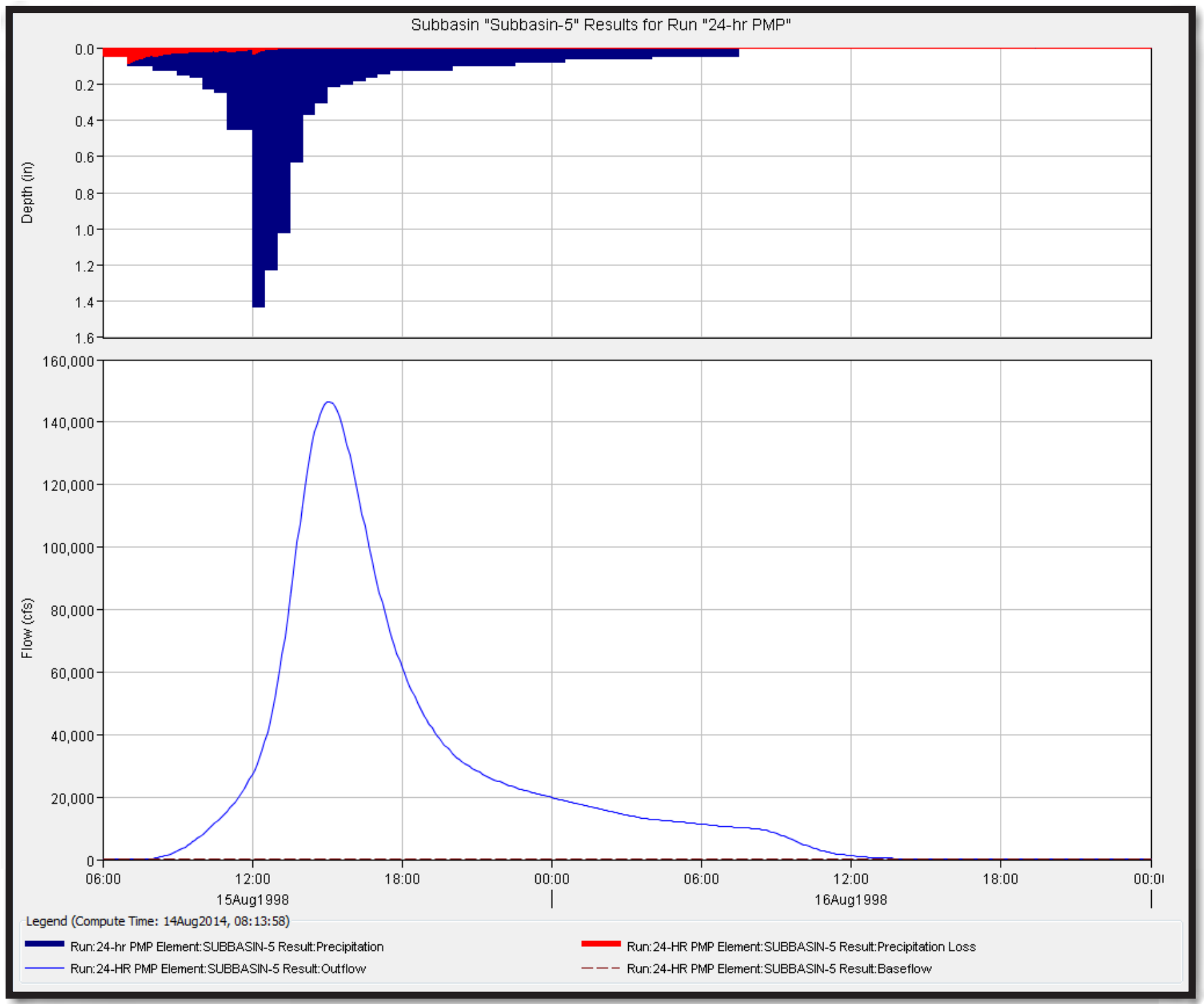

Figure 1-14. Output hydrograph screenshot for subbasin 5 from the 24-hour probable maximum precipitation (PMP) event. 
42 Dam Failure Analysis for the Lego de Matrullas Dam, Orocovis, Puerto Rico

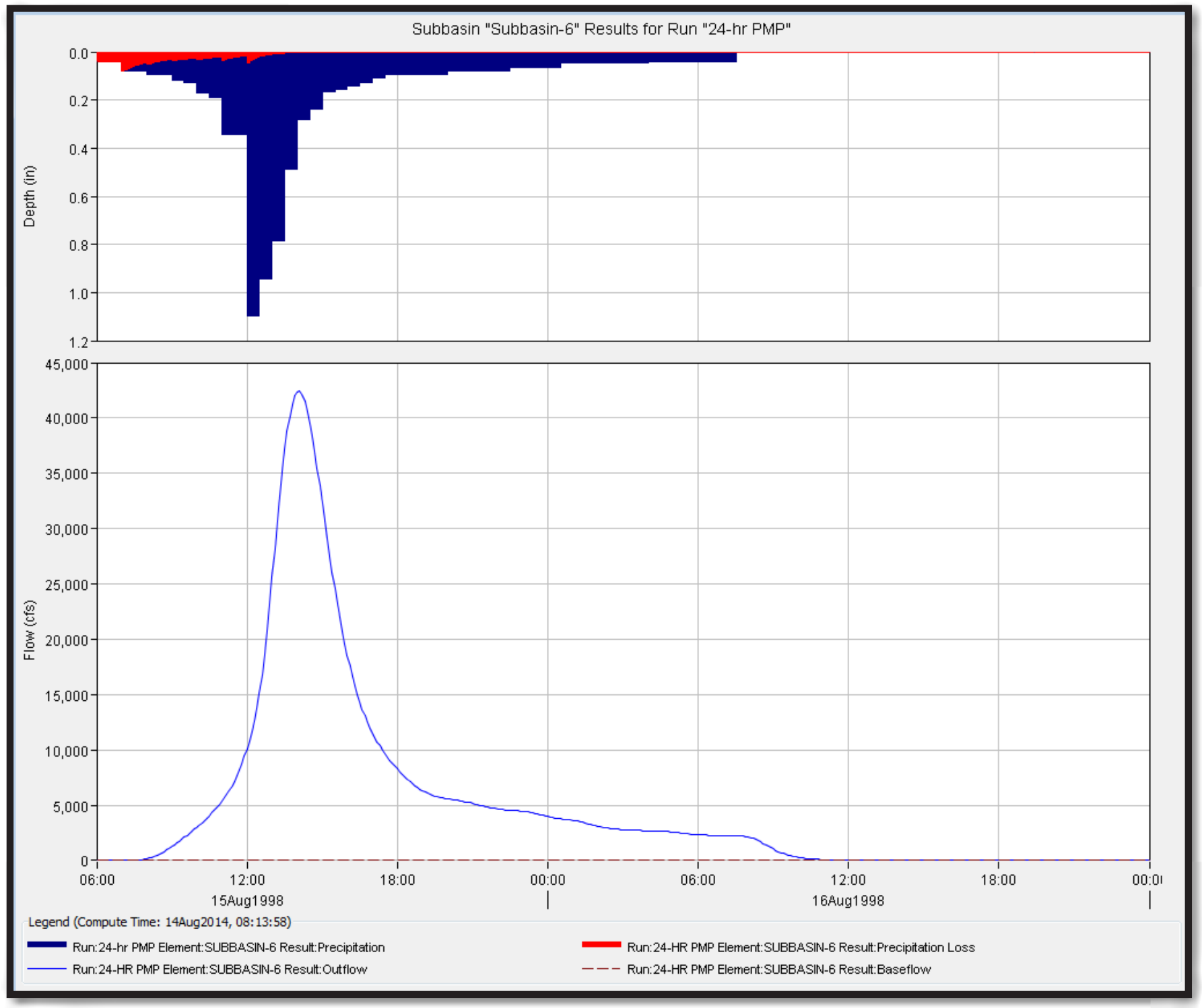

Figure 1-15. Output hydrograph screenshot for subbasin 6 from the 24-hour probable maximum precipitation (PMP) event. 


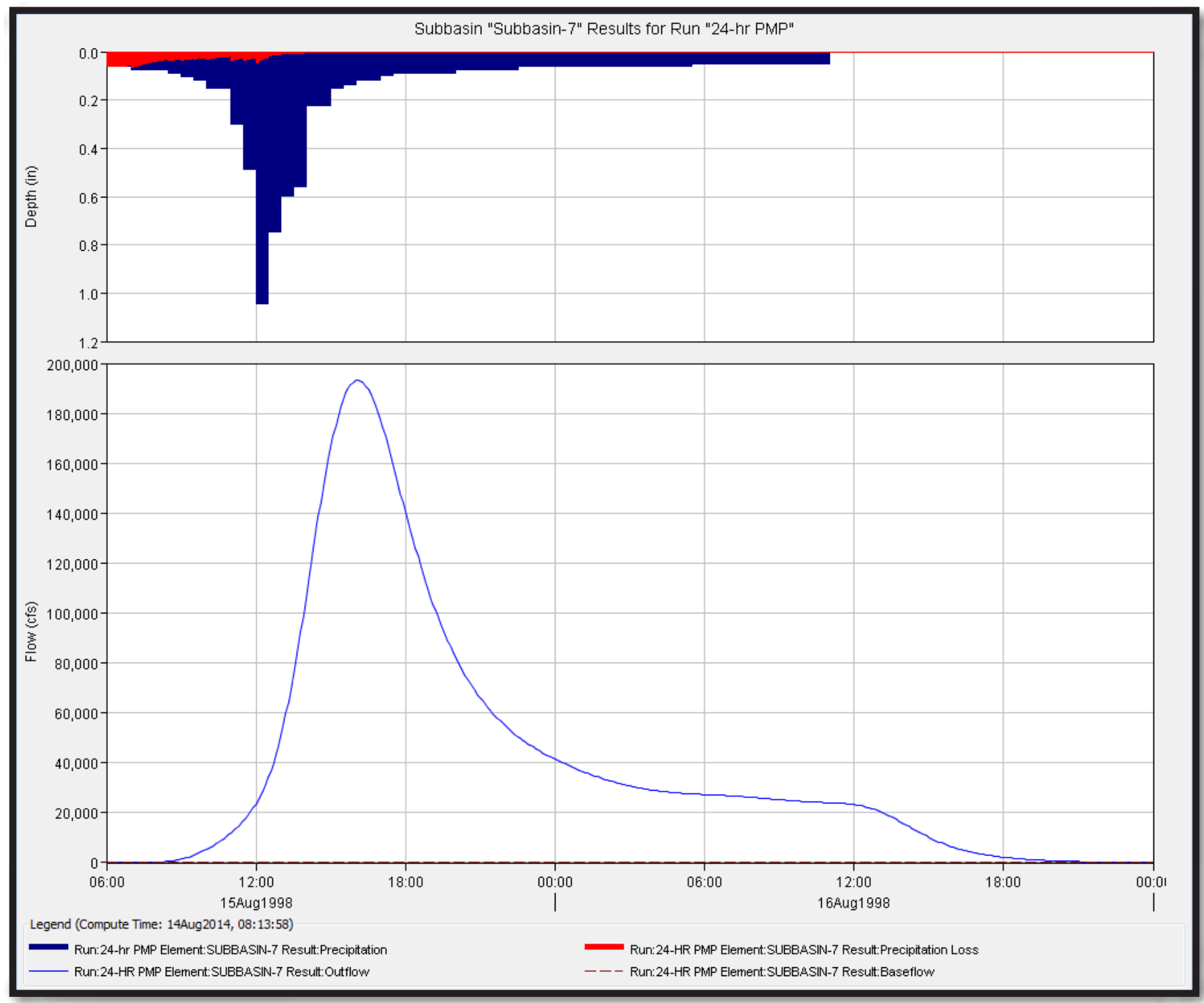

Figure 1-16. Output hydrograph screenshot for subbasin 7 from the 24-hour probable maximum precipitation (PMP) event. 


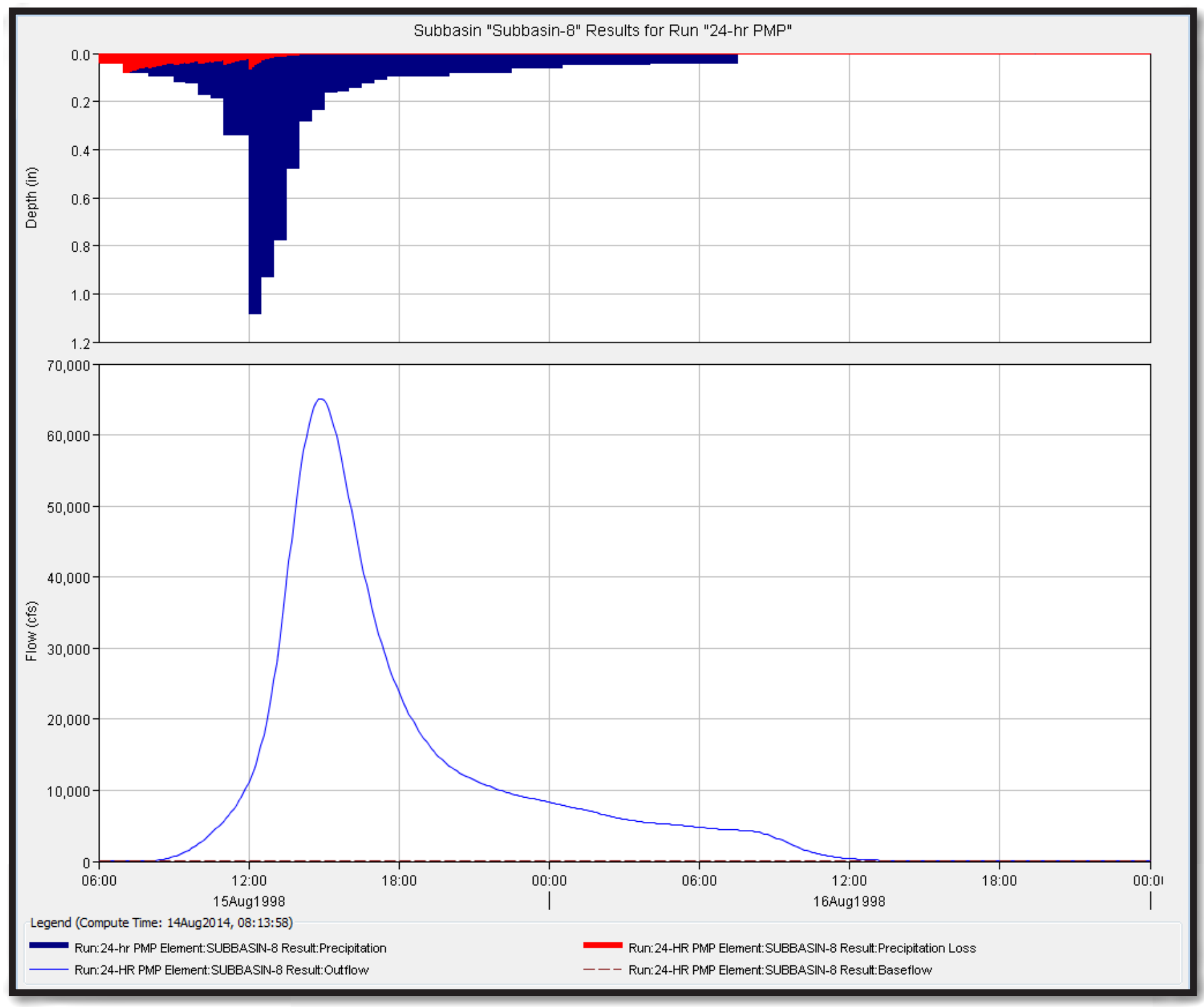

Figure 1-17. Output hydrograph screenshot for subbasin 8 from the 24-hour probable maximum precipitation (PMP) event. 


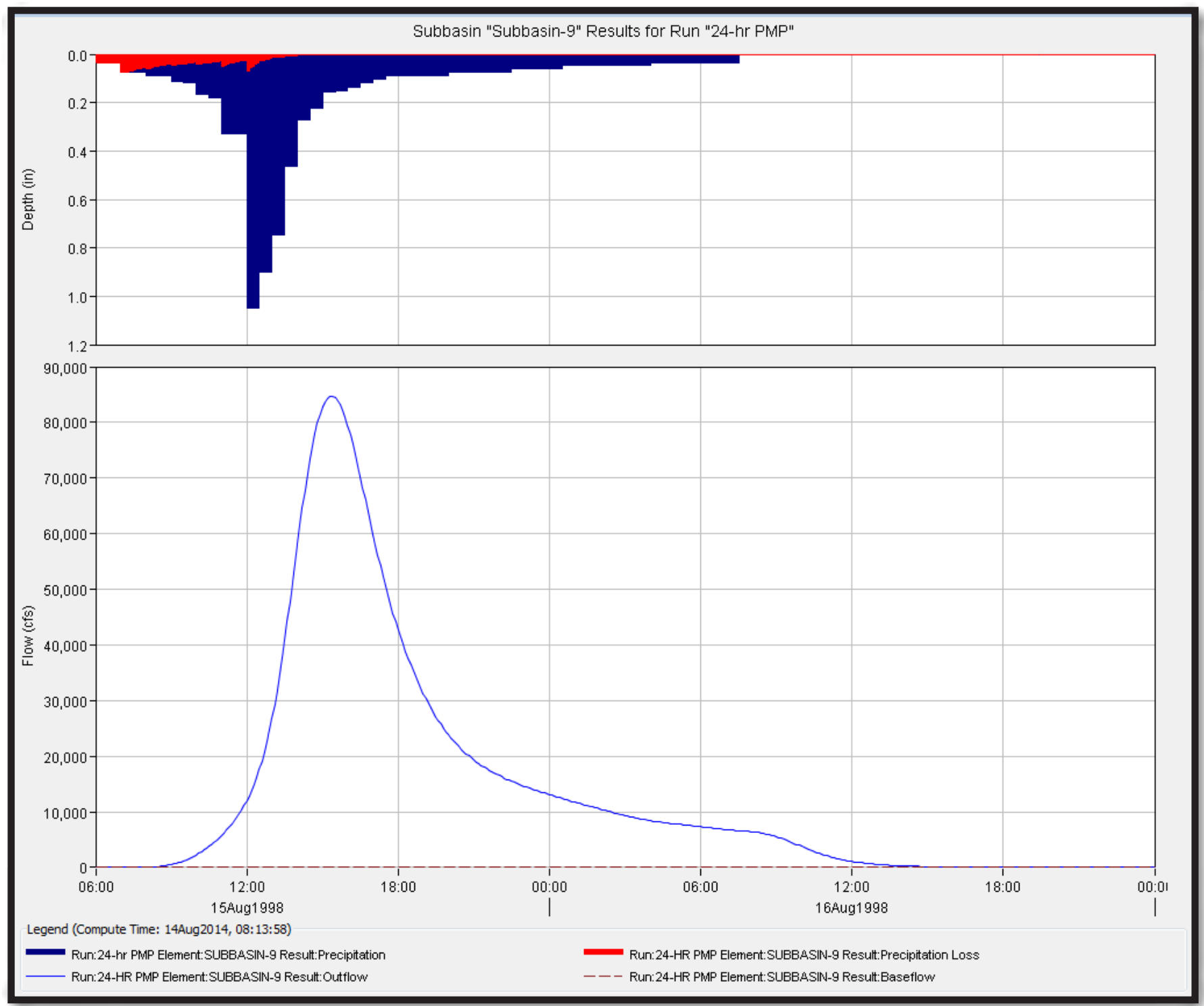

Figure 1-18. Output hydrograph screenshot for subbasin 9 from the 24-hour probable maximum precipitation (PMP) event. 


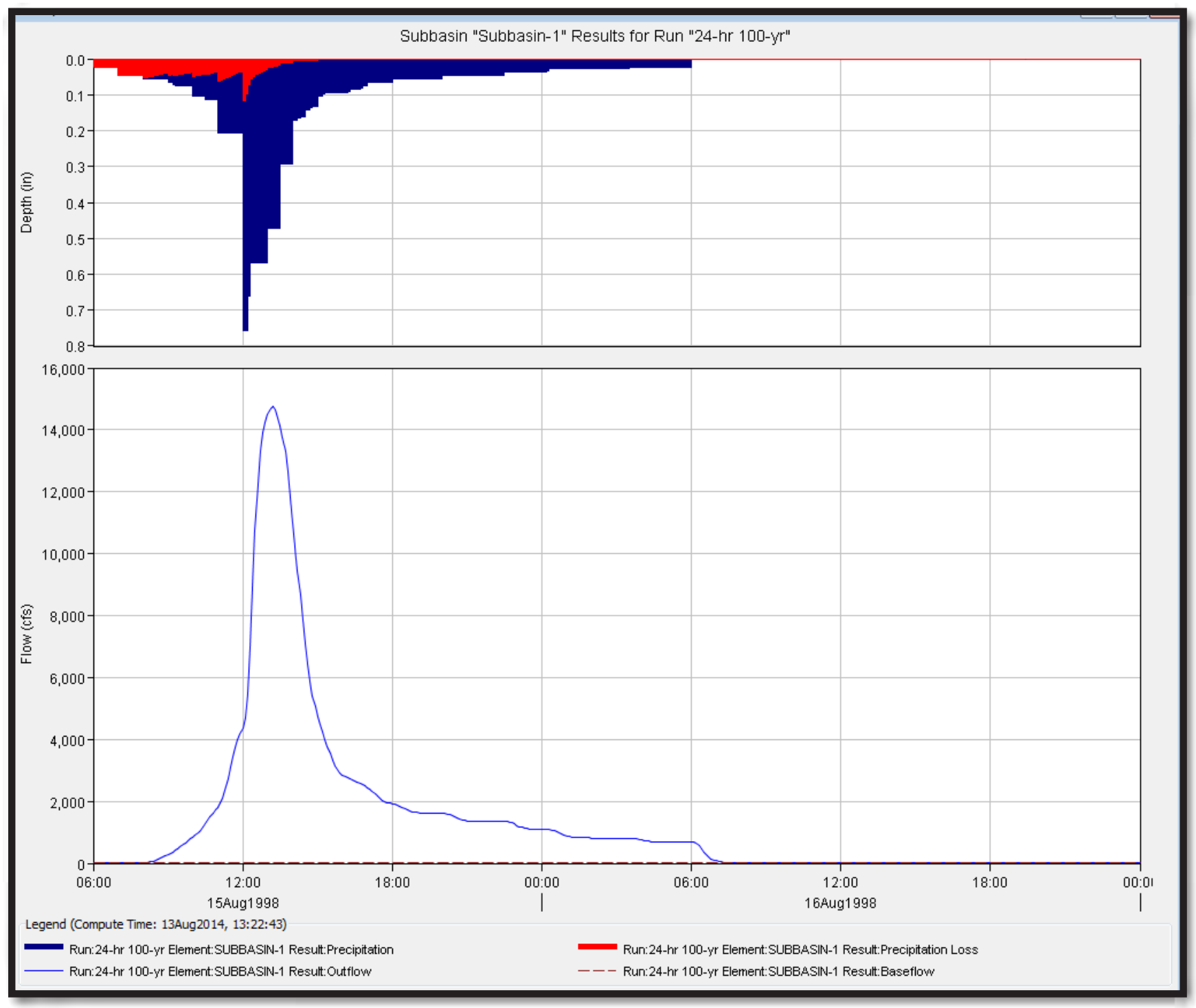

Figure 1-19. Output hydrograph screenshot for subbasin 1 from the 100-year-recurrence, 24-hour rainfall event. 


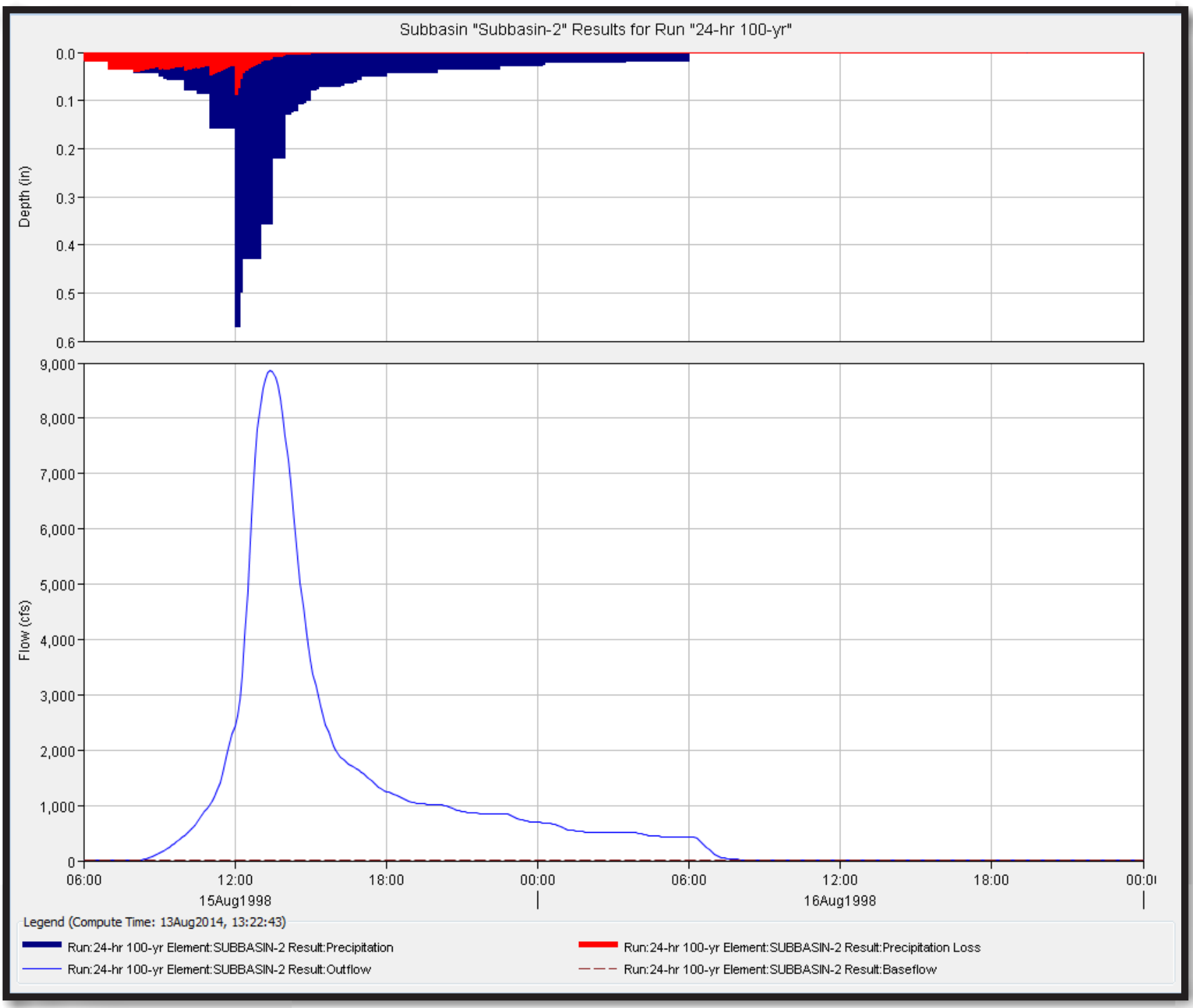

Figure 1-20. Output hydrograph screenshot for subbasin 2 from the 100-year-recurrence, 24-hour rainfall event. 


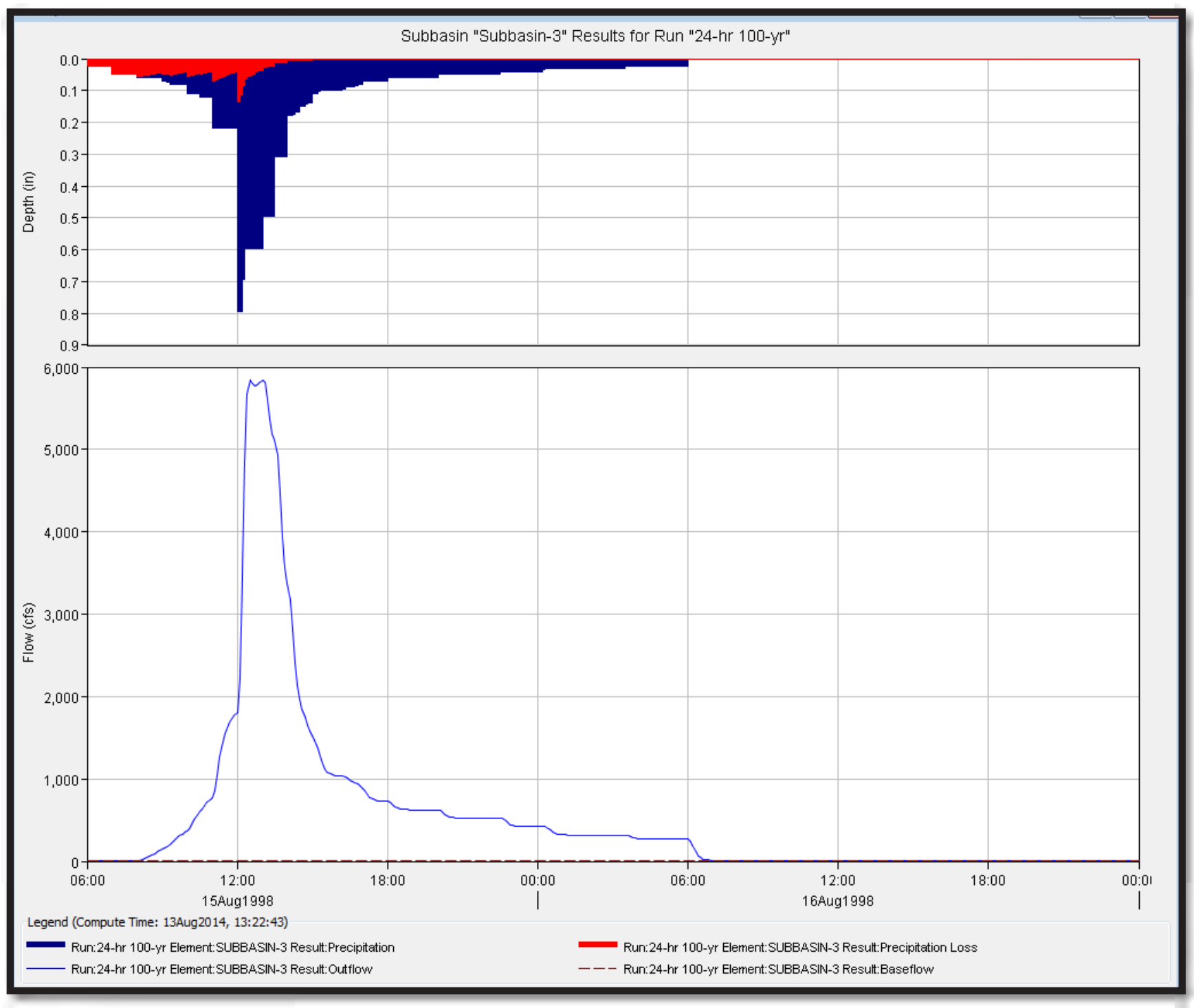

Figure 1-21. Output hydrograph screenshot for subbasin 3 from the 100-year-recurrence, 24-hour rainfall event. 


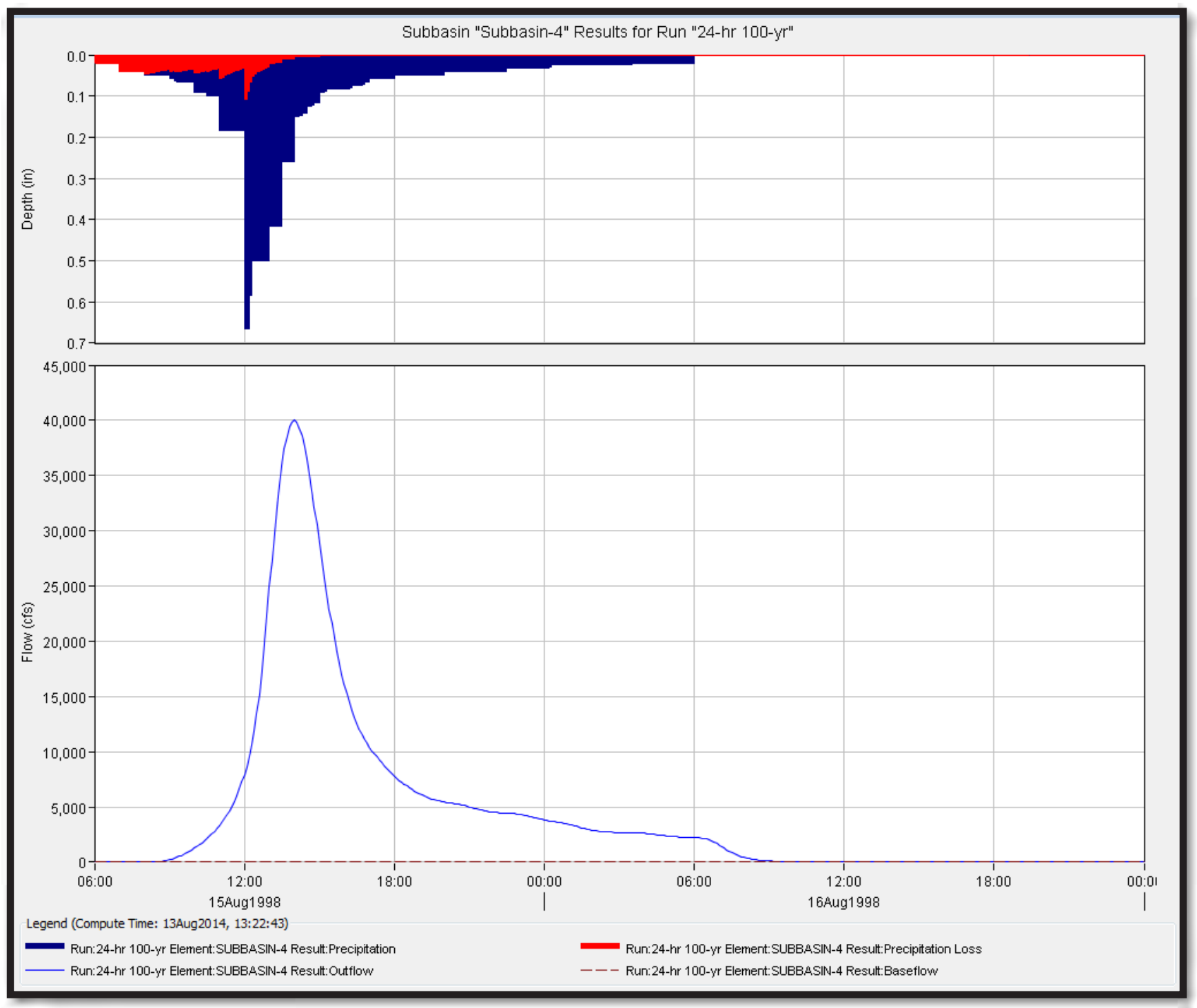

Figure 1-22. Output hydrograph screenshot for subbasin 4 from the 100-year-recurrence, 24-hour rainfall event. 


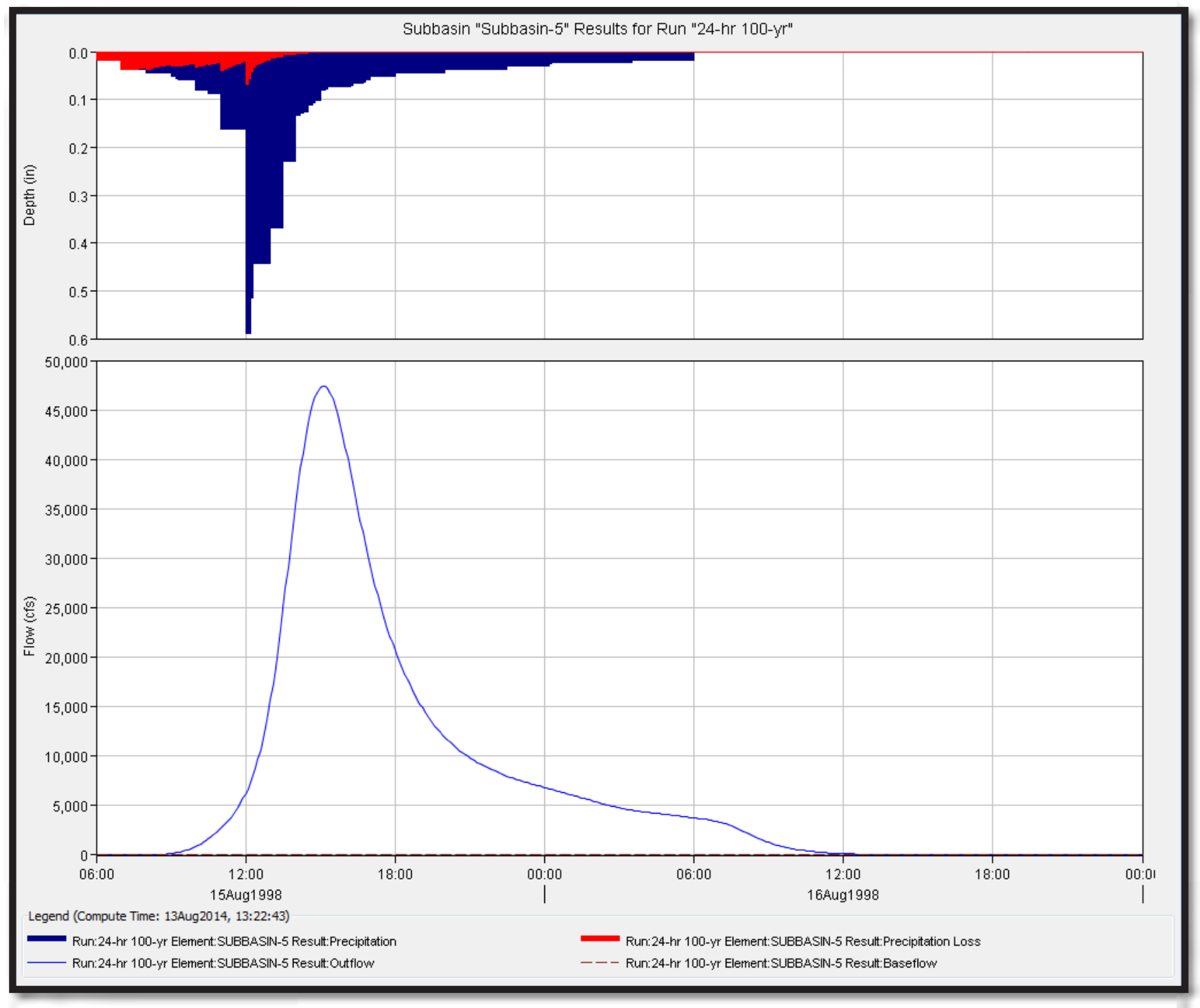

Figure 1-23. Output hydrograph screenshot for subbasin 5 from the 100-year-recurrence, 24-hour rainfall event. 


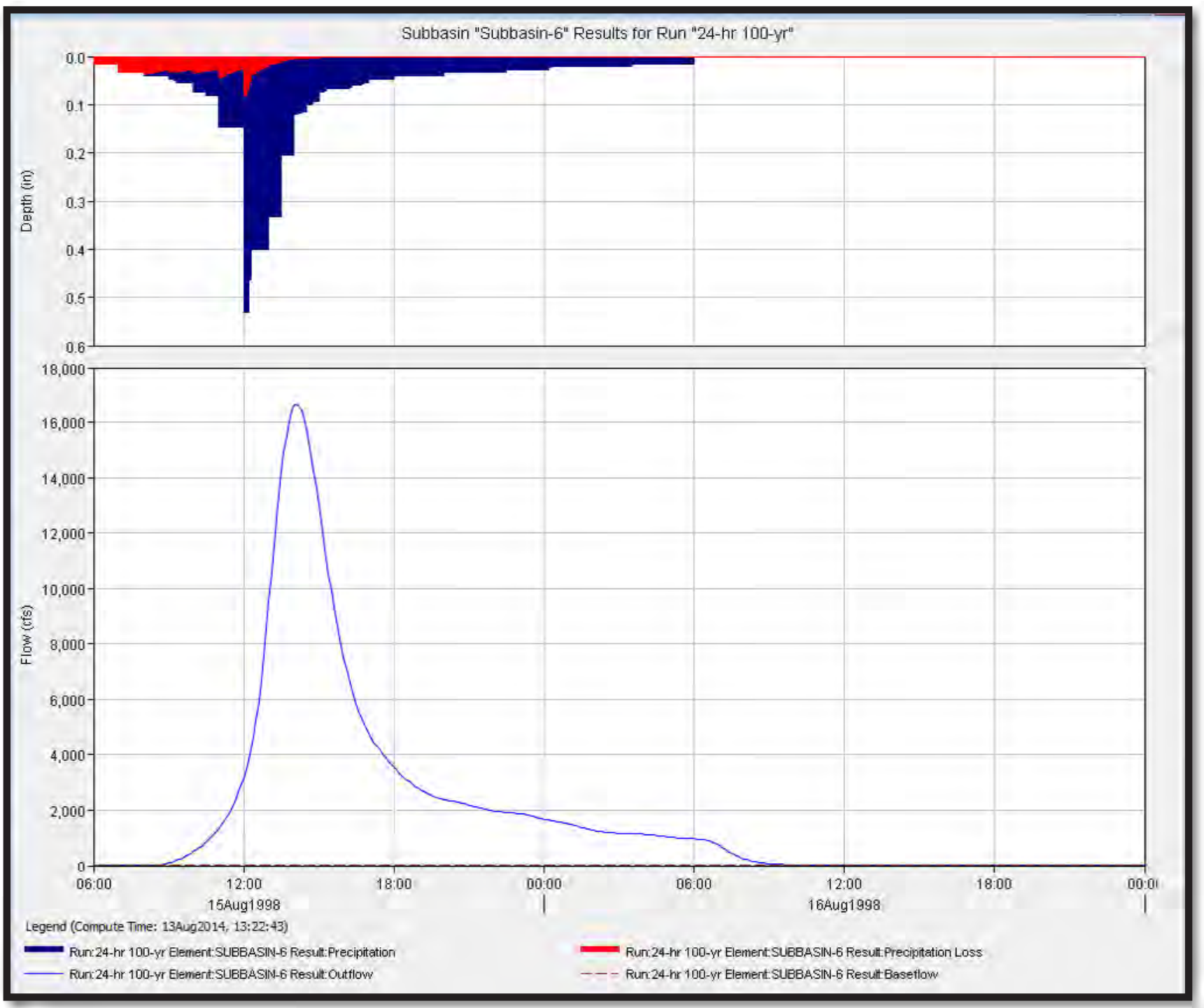

Figure 1-24. Output hydrograph screenshot for subbasin 6 from the 100-year-recurrence, 24-hour rainfall event. 


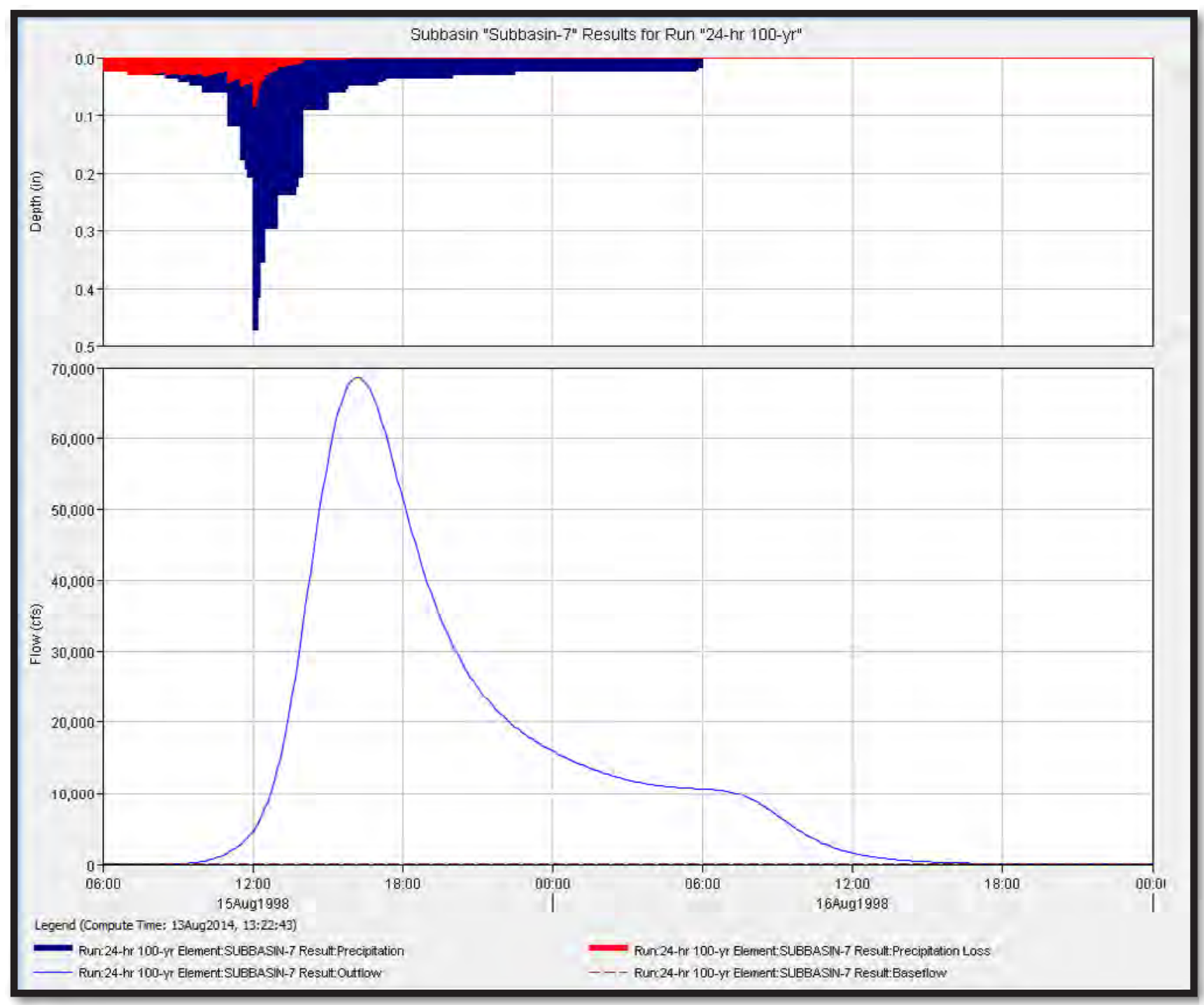

Figure 1-25. Output hydrograph screenshot for subbasin 7 from the 100-year-recurrence, 24-hour rainfall event. 
Appendix 1. HEC-HMS Output Hydrograph for the Dam Failure Analysis of Lago de Matrullas, Orocovis, Puerto Rico

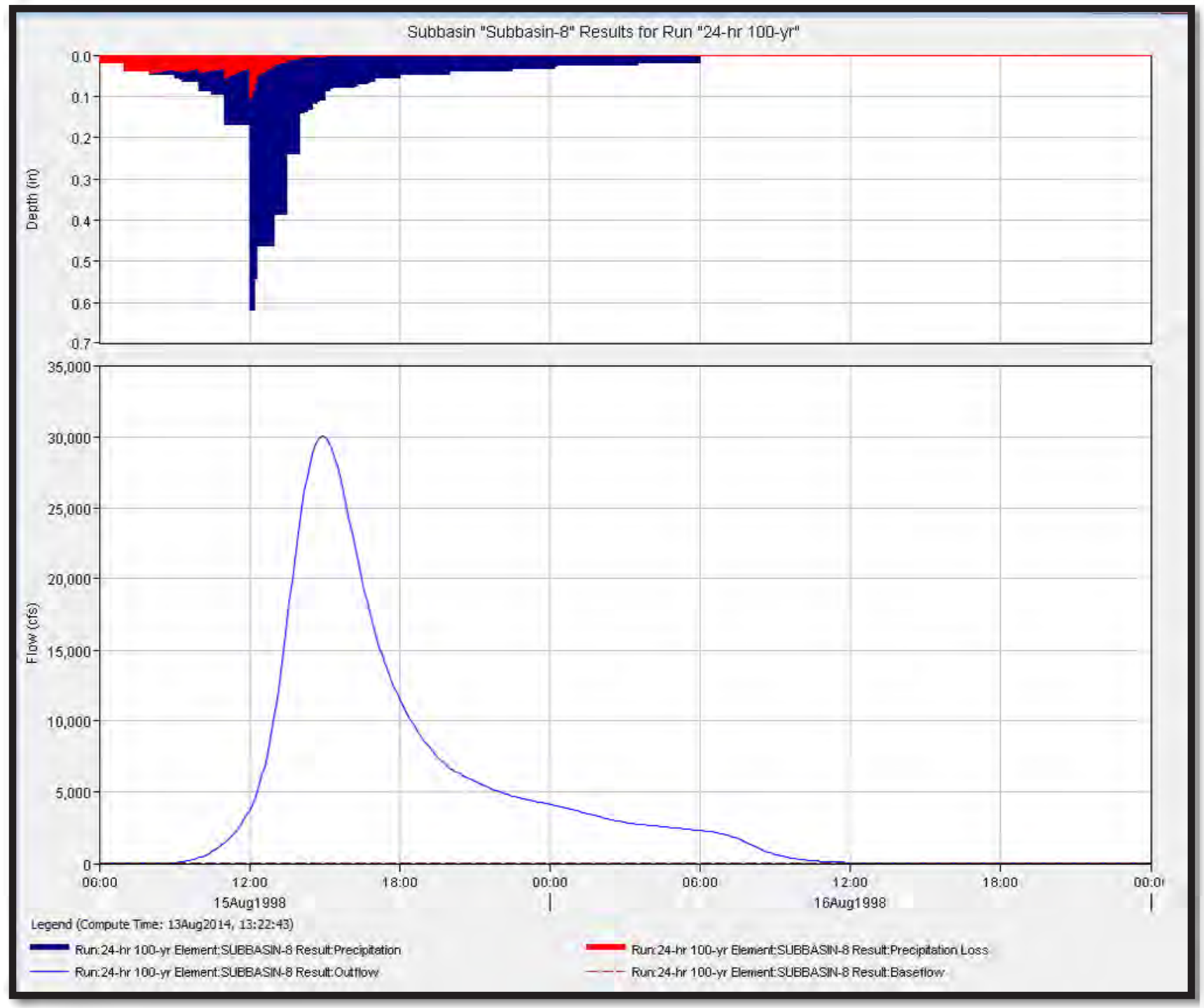

Figure 1-26. Output hydrograph screenshot for subbasin 8 from the 100-year-recurrence, 24-hour rainfall event. 
Dam Failure Analysis for the Lago de Matrullas Dam, Orocovis, Puerto Rico

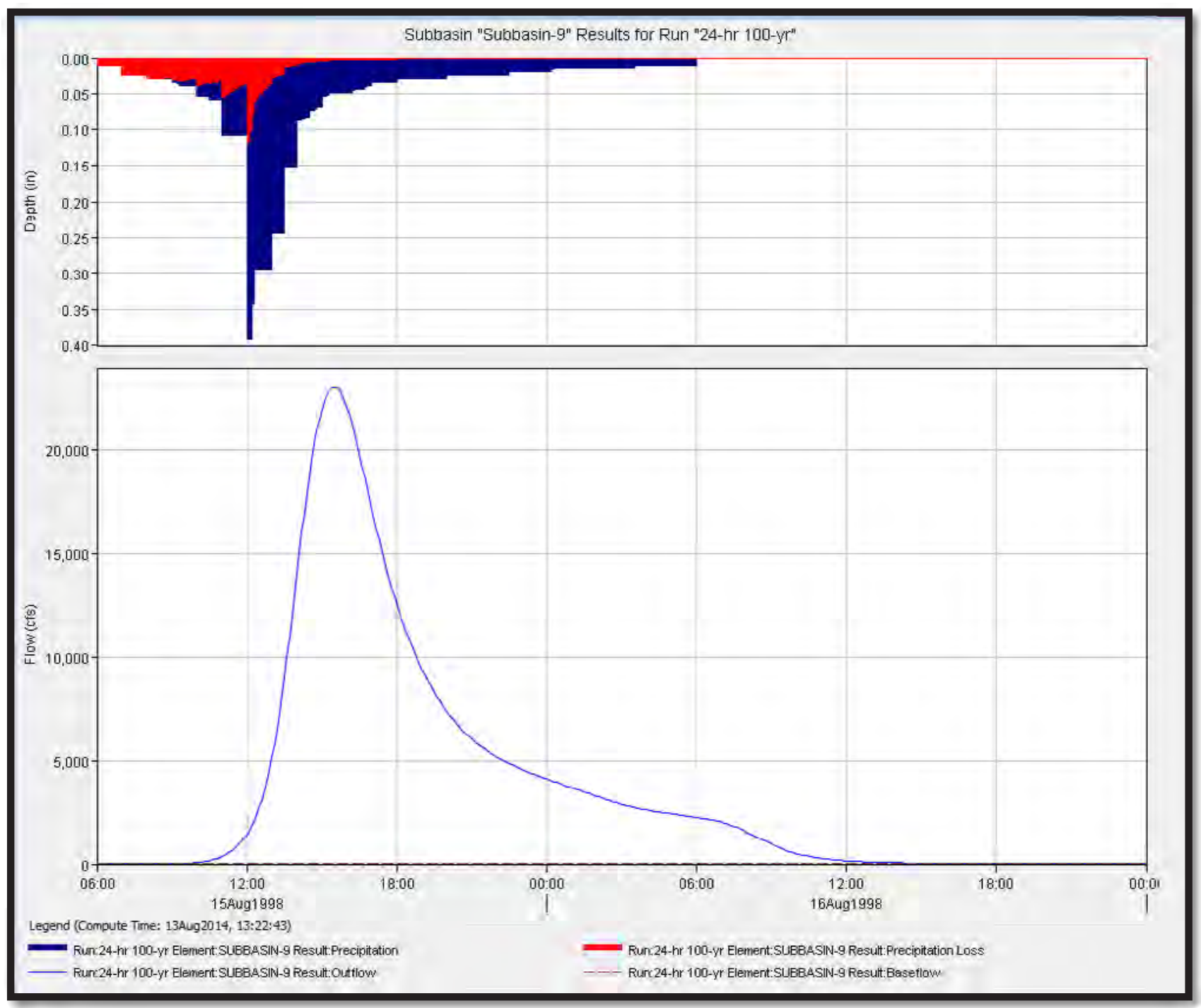

Figure 1-27. Output hydrograph screenshot for subbasin 9 from the 100-year-recurrence, 24-hour rainfall event. 
For further information about this publication contact:

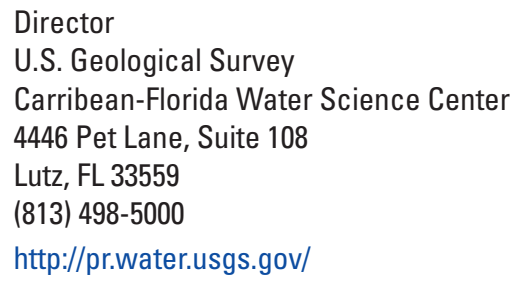


